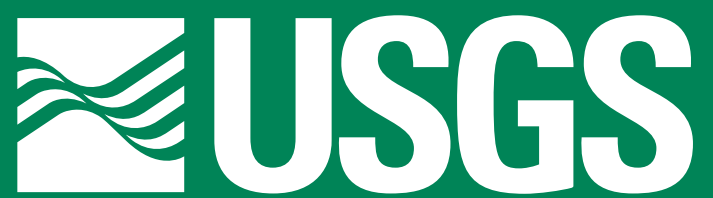

science for a changing world

\title{
Hydrology and Water Quality of an Urban Stream Reach in the Great Basin-Little Cottonwood Creek near Salt Lake City, Utah, Water Years 1999-2000
}

Water-Resources Investigations Report 02-4276
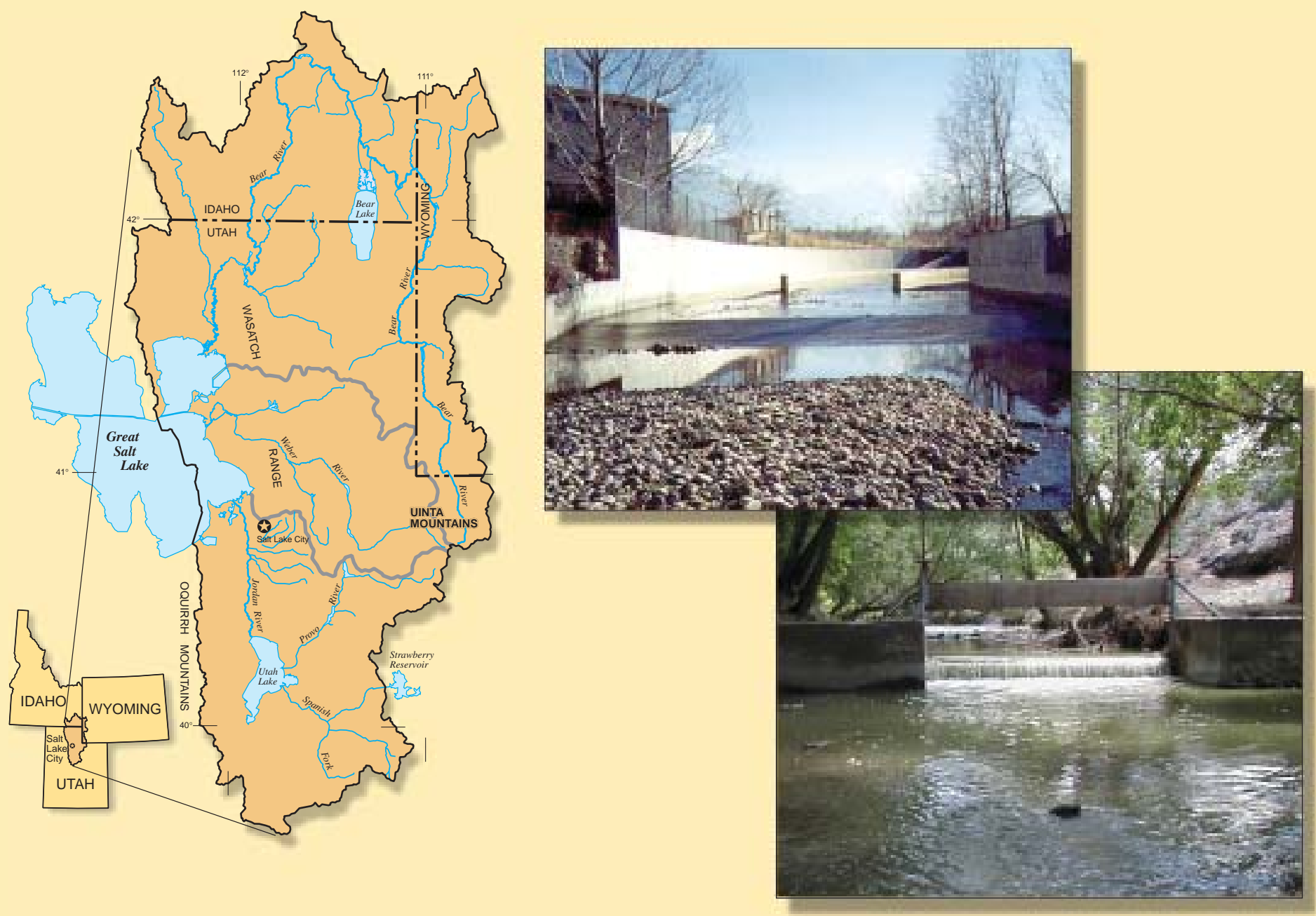

U.S. Department of the Interior

U.S. Geological Survey

National Water-Quality Assessment Program 


\section{Hydrology and Water Quality of an Urban Stream Reach in the Great Basin-Little Cottonwood Creek near Salt Lake City, Utah, Water Years 1999-2000}

By Steven J. Gerner and Kidd M. Waddell

U.S. Geological Survey

Water-Resources Investigations Report 02-4276

NATIONAL WATER-QUALITY ASSESSMENT PROGRAM 


\section{U.S. DEPARTMENT OF THE INTERIOR}

GALE A. NORTON, Secretary

\section{U.S. GEOLOGICAL SURVEY}

Charles G. Groat, Director

Any use of trade, product, or firm names in this publication is for descriptive purposes only and does not imply endorsement by the U.S. Government.

For additional information write to:

District Chief

U.S. Geological Survey

2329 Orton Circle

Salt Lake City, Utah 84119

http://ut.water.usgs.gov
Copies of this report can be purchased from:

U.S. Geological Survey

Branch of Information Services

Building 810

Box 25286, Federal Center

Denver, C0 80225-0286 


\section{FOREWORD}

The U.S. Geological Survey (USGS) is committed to serve the Nation with accurate and timely scientific information that helps enhance and protect the overall quality of life, and facilitates effective management of water, biological, energy, and mineral resources (http://www.usgs.gov/). Information on the quality of the Nation's water resources is of critical interest to the USGS because it is so integrally linked to the long-term availability of water that is clean and safe for drinking and recreation and that is suitable for industry, irrigation, and habitat for fish and wildlife. Escalating population growth and increasing demands for the multiple water uses make water availability, now measured in terms of quantity and quality, even more critical to the long-term sustainability of our communities and ecosystems.

The USGS implemented the National Water-Quality Assessment (NAWQA) program to support national, regional, and local information needs and decisions related to water-quality management and policy (http://water.usgs.gov/nawqa). Shaped by and coordinated with ongoing efforts of other Federal, State, and local agencies, the NAWQA program is designed to answer: What is the condition of our Nation's streams and ground water? How are the conditions changing over time? How do natural features and human activities affect the quality of streams and ground water, and where are those effects most pronounced? By combining information on water chemistry, physical characteristics, stream habitat, and aquatic life, the NAWQA program aims to provide sciencebased insights for current and emerging water issues and priorities. NAWQA results can contribute to informed decisions that result in practical and effective water-resource management and strategies that protect and restore water quality.

Since 1991, the NAWQA program has implemented interdisciplinary assessments in more than 50 of the Nation's most important river basins and aquifers, referred to as Study Units (http://water.usgs.gov/nawqa/ nawqamap.html). Collectively, these Study Units account for more than 60 percent of the overall water use and population served by public water supply, and are representative of the Nation's major hydrologic landscapes, priority ecological resources, and agricultural, urban, and natural sources of contamination.

Each assessment is guided by a nationally consistent study design and methods of sampling and analysis. The assessments thereby build local knowledge about water-quality issues and trends in a particular stream or aquifer while providing an understanding of how and why water quality varies regionally and nationally. The consistent, multi-scale approach helps to determine if certain types of water-quality issues are isolated or pervasive, and allows direct comparisons of how human activities and natural processes affect water quality and ecological health in the Nation's diverse geographic and environmental settings. Comprehensive assessments on pesticides, nutrients, volatile organic compounds, trace metals, and aquatic ecology are developed at the national scale through comparative analysis of the Study-Unit findings (http://water.usgs.gov/nawqa/natsyn.html).

The USGS places high value on the communication and dissemination of credible, timely, and relevant science so that the most recent and available knowledge about water resources can be applied in management and policy decisions. We hope this NAWQA publication will provide you the needed insights and information to meet your needs, and thereby foster increased awareness and involvement in the protection and restoration of our Nation's waters.

The NAWQA program recognizes that a national assessment by a single program cannot address all waterresource issues of interest. External coordination at all levels is critical for a fully integrated understanding of watersheds and for cost-effective management, regulation, and conservation of our Nation's water resources. The program, therefore, depends extensively on the advice, cooperation, and information from other Federal, State, interstate, Tribal, and local agencies, non-government organizations, industry, academia, and other stakeholder groups. The assistance and suggestions of all are greatly appreciated.

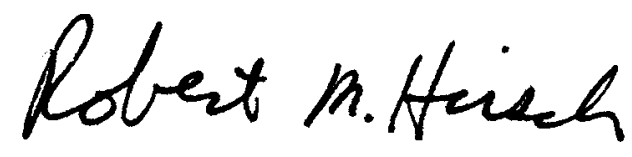

Robert M. Hirsch

Associate Director for Water 


\section{CONTENTS}

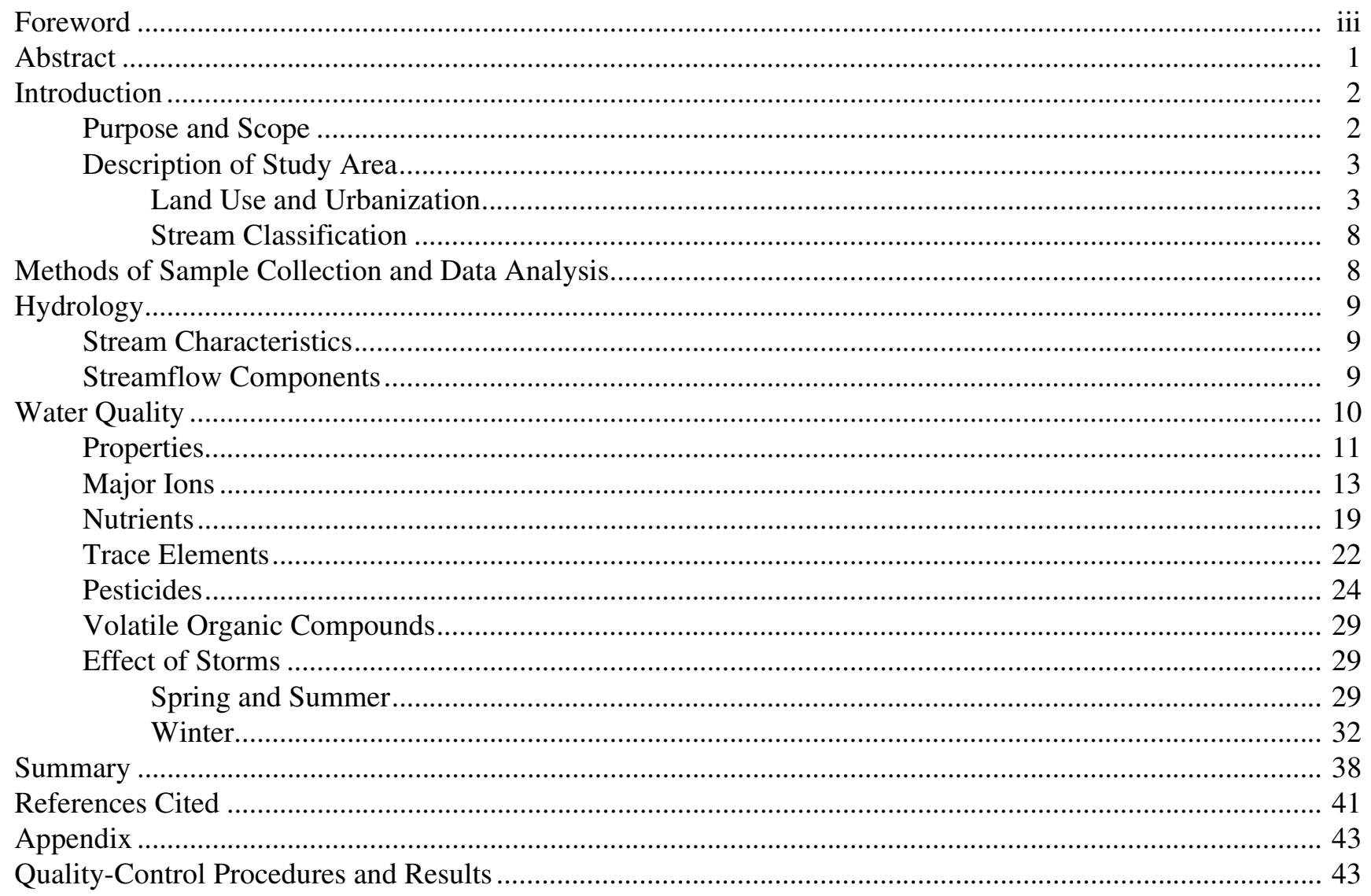




\section{FIGURES}

Figure 1. Map showing location of study area, fixed sites, historic' smelter sites, and photographs showing area near fixed sites 1 and 2, and headwaters of Little Cottonwood Creek in Albion

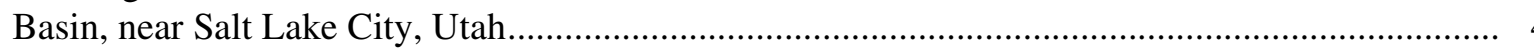

Figure 2. Map showing location of sample sites, Little Cottonwood Creek, near Salt Lake City, Utah,

Figure 3. Map showing land use/cover of Little Cottonwood Creek drainage basin, near Salt Lake

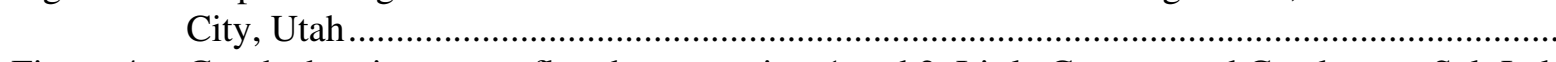

Figure 4. Graph showing streamflow between sites 1 and 2, Little Cottonwood Creek, near Salt Lake

City, Utah, August 31 and September 2, 1999

Figure 5. Graph showing daily mean streamflow and temporal distribution of water-quality samples at

Figure 6. Graph showing monthly streamflow at sites 1 and 2 on Little Cottonwood Creek, near Salt

Figure 7. Graphs showing daily mean streamflow and specific conductance at sites 1 and 2 on Little

Figure 8. Graphs showing relation of chloride and sodium concentration to specific conductance at sites 1

and 2 on Little Cottonwood Creek, near Salt Lake City, Utah....

Figure 9. Boxplots showing (A) dissolved oxygen, in percent saturation, (B) dissolved-oxygen concentration, and (C) pH at sites 1 and 2 on Little Cottonwood Creek, near Salt Lake City, Utah, 1999-2000 water years

Figure 10. Graphs showing cumulative frequency curves of daily mean water temperature for sites 1 and 2 on Little Cottonwood Creek, near Salt Lake City, Utah, 1999-2000 water years, and water temperature on August 1, 1999, and April 1, 2000, at sites 1 and 2

Figure 11. Graphs showing chemical composition of streamflow at sites 1 and 2 on Little Cottonwood Creek, near Salt Lake City, Utah, 1999 water year

Figure 12. Trilinear diagram showing composition of water samples collected from sites 1, S6, S8, and 2 on Little Cottonwood Creek, near Salt Lake City, Utah.

Figure 13. Graphs showing relation of concentration of total phosphorus and dissolved nitrite plus nitrate to streamflow at sites 1 and 2, Little Cottonwood Creek, near Salt Lake City, Utah.

Figure 14. Graph showing relation of concentration of suspended sediment to total phosphorus in samples from sites 1 and 2, Little Cottonwood Creek, near Salt Lake City, Utah

Figure 15. Boxplot showing percentage of phosphorus in the suspended phase in samples from sites 1 and 2, Little Cottonwood Creek, near Salt Lake City, Utah

Figure 16. Graphs showing relation of concentration of arsenic and copper to streamflow at sites 1 and 2 on Little Cottonwood Creek, near Salt Lake City, Utah.

Figure 17. Graph showing concentration of arsenic, copper, and zinc in water collected from Little Cottonwood Creek, near Salt Lake City, Utah, August 31 and September 2, 1999

Figure 18. Graphs showing seasonal variability of selected pesticide concentrations at site 2 on Little Cottonwood Creek, near Salt Lake City, Utah

Figure 19. Graph showing concentration of selected pesticides at sites 1 and S6 on Little Cottonwood Creek, September 2, 1999, and sites S8 and 2 on Little Cottonwood Creek, near Salt Lake City, Utah, August 31, 1999 
Figure 20. Graphs showing relation of number of volatile organic compounds detected to (A) dissolved organic carbon, (B) water temperature, and (C) seasonal streamflow at site 2 on Little Cottonwood Creek, near Salt Lake City, Utah

Figure 21. Hydrograph showing streamflow and temporal distribution of water-quality samples at sites 1 and 2 on Little Cottonwood Creek, near Salt Lake City, Utah, during storm on April 14, 2000 ...... 38

Figure 22. Graph showing relation of mean concentration of (A) total ammonia plus organic nitrogen, total nitrogen, and total phosphorus, and (B) atrazine, carbaryl, diazinon, and prometon at sites 1 and 2, and in runoff between sites 1 and 2 in non-storm and storm samples, Little Cottonwood Creek, near Salt Lake City, Utah 


\section{TABLES}

Table 1. Minimum reporting level of parameters and constituents measured at fixed sites on Little Cottonwood Creek, near Salt Lake City, Utah

Table 2. Summary of nutrient concentration in water samples collected from sites 1 and 2 on Little Cottonwood Creek, near Salt Lake City, Utah

Table 3. Summary of trace-element concentration in water samples collected from sites 1 and 2 on Little Cottonwood Creek, near Salt Lake City, Utah

Table 4. Minimum reporting level of pesticides analyzed for in water samples collected at fixed sites on Little Cottonwood Creek, near Salt Lake City, Utah

Table 5. Summary of pesticides analyzed for by gas chromatography/mass spectrometry and detected in water samples collected from sites 1 and 2 on Little Cottonwood Creek, near Salt Lake City, Utah 30

Table 6. Minimum reporting level of volatile organic compounds analyzed for in water samples collected at fixed sites on Little Cottonwood Creek, near Salt Lake City, Utah

Table 7. Summary of volatile organic compounds detected in water samples from sites 1 and 2 on Little Cottonwood Creek, near Salt Lake City, Utah

Table 8. Load and mean concentration of selected constituents at sites 1 and 2, and in runoff between sites 1 and 2, on Little Cottonwood Creek, near Salt Lake City, Utah, calculated for a storm on April 14, 2000

Table 9. Summary of constituents detected in field blanks collected from basic fixed sites in the Great Salt Lake Basins study unit

Table 10. Summary of surrogate and field matrix spike recovery in water samples collected from basic fixed sites in the Great Salt Lake Basins study unit 45

Table 11. Summary of relative percent difference between constituents detected in split replicate sample pairs collected from fixed sites in the Great Salt Lake Basins study unit 


\section{CONVERSION FACTORS, DATUMS, AND ABBREVIATED WATER-QUALITY UNITS}

\begin{tabular}{rcl}
\hline Multiply & By & To obtain \\
\hline acre-foot (acre-ft) & 1,233 & cubic meter \\
cubic foot per second $\left(\mathrm{ft}^{3} / \mathrm{s}\right)$ & 0.02832 & cubic meter per second \\
foot $(\mathrm{ft})$ & 0.3048 & meter \\
inch (in.) & 25.4 & millimeter \\
mile (mi) & 1.609 & kilometer \\
square mile $\left(\mathrm{mi}^{2}\right)$ & 2.590 & square kilometer \\
\hline
\end{tabular}

Water temperature is reported in degrees Celsius $\left({ }^{\circ} \mathrm{C}\right)$, which can be converted to degrees Fahrenheit $\left({ }^{\circ} \mathrm{F}\right)$ by the following equation:

$$
{ }^{\circ} \mathrm{F}=1.8\left({ }^{\circ} \mathrm{C}\right)+32 \text {. }
$$

Vertical coordinate information is referenced to the National Geodetic Vertical Datum of 1929 (NGVD 1929). Horizontal coordinate information is referenced to the North American Datum of 1983 (NAD 83).

Chemical concentration and water temperature are reported only in metric units. Chemical concentration is reported in milligrams per liter $(\mathrm{mg} / \mathrm{L})$ or micrograms per liter $(\mu \mathrm{g} / \mathrm{L})$. Milligrams per liter is a unit expressing the solute per unit volume (liter) of water. One thousand micrograms per liter is equivalent to 1 milligram per liter. For concentrations less than 7,000 milligrams per liter, the numerical value is about the same as for concentrations in parts per million. Chemical load is a product of chemical concentration and streamflow and is reported in kilograms $(\mathrm{kg})$ and grams $(\mathrm{g})$. Specific conductance is reported in microsiemens per centimeter at 25 degrees Celsius $(\mu \mathrm{S} / \mathrm{cm})$.

Water year is the 12-month period from October 1 through September 30. The water year is designated by the calendar year in which it ends. Thus, the 12-month period ending September 30, 1999, is water year 1999 . 


\section{Hydrology and Water Quality of an Urban Stream Reach in the Great Basin-Little Cottonwood Creek near Salt Lake City, Utah, Water Years 1999-2000}

\section{By Steven J. Gerner and Kidd M. Waddell}

\section{ABSTRACT}

The hydrology and water quality of an urbanized reach of Little Cottonwood Creek near Salt Lake City, Utah, were examined as part of the Great Salt Lake Basins study, part of the U.S. Geological Survey National Water-Quality Assessment program. Physical and chemical properties of the stream were referenced to established aquatic-life criteria as available. Two fixed sampling sites were established on Little Cottonwood Creek with the purpose of determining the influence of urbanization on the water quality of the stream. The fixed-site assessment is a component of the National WaterQuality Assessment surface-water study design used to assess the spatial and temporal distribution of selected water-quality constituents.

The occurrence and distribution of major ions, nutrients, trace elements, dissolved and suspended organic carbon, pesticides, volatile organic compounds, and suspended sediment were monitored during this study. From October 1998 to September 2000, stream samples were collected at regular intervals at the two fixed sites. Additional samples were collected at these sites during periods of high flow, which included runoff from snowmelt in the headwaters and seasonal thunderstorms in the lower basin.

Arsenic was detected in 16 of 25 samples from site 1 in concentrations ranging from 0.7 to 7.5 micrograms per liter $(\mu \mathrm{g} / \mathrm{L})$. Arsenic was detected in all 49 samples collected from site 2, with concentrations ranging from 4.7 to $284 \mu \mathrm{g} / \mathrm{L}$. Surface runoff and sub-surface drainage near smelter tailings are likely sources of arsenic solutes. The U.S. Environmental Protection Agency aquatic-life criterion of $150 \mu \mathrm{g} / \mathrm{L}$ was exceeded in 8 of 49 samples at site 2 .

Several pesticides were detected in more than 40 percent of the samples from sites 1 and 2 . Prometon was the most frequently detected pesticide and was measured at higher concentrations than any other detected pesticide. Maximum measured prometon concentration was $0.98 \mu \mathrm{g} / \mathrm{L}$ at site 1 and $5.61 \mu \mathrm{g} / \mathrm{L}$ at site 2 .

Samples collected for volatile organic compounds at sites 1 and 2 were analyzed for 86 compounds. At site 2, 28 compounds were detected. Toluene was detected at site 2 at a maximum concentration of $3.15 \mu \mathrm{g} / \mathrm{L}$, which exceeded the aquatic-life criterion of $2 \mu \mathrm{g} / \mathrm{L}$.

Runoff from urban land cover is a substantial source of nutrients and pesticides to Little Cottonwood Creek. Nutrient concentrations calculated in runoff to the stream between sites 1 and 2 during a storm on April 14, 2000, were generally much higher than the mean concentration calculated for the storm at either site 1 or 2 . Atrazine, carbaryl, dacthal, and prometon concentrations calculated for inflow between sites 1 and 2 during the storm were more than twice the mean concentration calculated for the storm at site 1 and more than 30 percent higher than the mean concentration at site 2 .

Specific-conductance values and chloride concentration increased in the urbanized reach of Little Cottonwood Creek during and following most winter storms. These increases were likely the result of road salting. The U.S. Environmental Protection Agency has recommended that the concentration of chloride not exceed $860 \mathrm{mg} / \mathrm{L}$ for more than 1 hour every 3 years or exceed a 4-day 
average concentration of $230 \mathrm{mg} / \mathrm{L}$ more than once every 3 years. Estimates of chloride concentration determined from specific-conductance values indicate that chloride concentrations at site 2 exceeded $860 \mathrm{mg} / \mathrm{L}$ about 9 percent of the time during December through March and exceeded a 4-day average of $230 \mathrm{mg} / \mathrm{L}$ more than 30 times during the study period. A higher percentage of algae was identified in taxa more tolerant of salinity in samples from site 2 than from site 1 , most likely because water with a higher salinity enters the stream between sites 1 and 2 .

\section{INTRODUCTION}

The National Water-Quality Assessment (NAWQA) program of the U.S. Geological Survey (USGS) began full-scale implementation in 1991. The objectives of the NAWQA program are to describe the status of and trends in the quality of the Nation's ground-water and surface-water resources as well as develop an understanding of the natural and human factors affecting those resources (Gilliom and others, 1995). The Great Salt Lake Basins study unit in Utah, Idaho, and Wyoming (fig. 1) is 1 of 51 study units that are included in this national program. The environmental setting and description of the Great Salt Lake Basins study unit are presented in Baskin and others (2002). The fixed-site assessment is a component of the NAWQA surface-water study design used to assess the spatial and temporal distribution of selected water-quality constituents. Fixed sites are those locations on a stream where water samples are collected at a fixed frequency and a continuous record of streamflow is available. Sites are chosen to represent specific environmental settings, such as agricultural land or urban land, or to represent integration of multiple land uses. The latter sites are most often located at the major nodes in a drainage system.

Two fixed sites were established on Little Cottonwood Creek, a tributary to the Jordan River, with the purpose of determining the influence of urban land uses on the water quality of the stream. Site 1 , Little Cottonwood Creek at Crestwood Park, is about $4 \mathrm{mi}$ downstream of the mouth of Little Cottonwood Canyon and was established to provide a baseline for evaluating the influence of the urban area on water quality (fixed site 1, fig. 1). Site 2, Little Cottonwood Creek at Jordan
River, is about $0.7 \mathrm{mi}$ above the confluence with the Jordan River and was established in conjunction with site 1 to determine the effects of urbanization on water quality in the stream reach between sites 1 and 2 (fixed site 2, fig. 1). The distance between sites 1 and 2 is about $5.7 \mathrm{mi}$. and the basin area between the sites is nearly 100 percent urban land cover.

Data for this study were collected from October 1998 through September 2000, encompassing the 1999 and 2000 water years. A synoptic study, a short-term investigation of water quality used to provide improved spatial coverage for selected water-quality conditions, was conducted in August and September 1999 and provided additional information on occurrence and spatial distribution of nutrients, trace metals, and pesticides during low flow periods in the reach between sites 1 and 2.

This synoptic study included a tracer-injection study conducted in the Little Cottonwood Creek reach between sites 1 and 2 to determine areas of groundwater discharge and identify areas where solutes may be entering the stream. Increases in stream solute loads or streamflow where no inflows are visible can indicate an area where ground water is discharging to the stream. Water samples for the tracer-injection study were collected from the sites shown in figure 2 .

Water-quality issues of particular importance in the urban reach of Little Cottonwood Creek include constituents in storm-water runoff, trace metals entering the stream near historic ore smelting sites, and elevated chloride and sodium concentrations most likely caused by road salting.

\section{Purpose and Scope}

This report (1) describes the stream hydrology and water quality in an urban reach of Little Cottonwood Creek from October 1, 1998, to September $30,2000,(2)$ relates changes in water quality to constituent sources, and (3) relates constituent concentrations to established aquatic-life criteria. The occurrence and distribution of major ions, nutrients, trace metals, dissolved and suspended organic carbons, pesticides, volatile organic compounds, and suspended sediment are reported.

Data used in this report are available in the National Water Information System (NWIS) database and the NAWQA Data Warehouse maintained by the USGS. This database is subject to periodic review and 
possible revision. Major ion, nutrient, trace metal, dissolved and suspended organic carbon, and sediment data also are available in USGS Water-Data Reports (Herbert and others, 2000, 2001, and 2002).

\section{Description of Study Area}

Little Cottonwood Creek flows west out of the Wasatch Mountains and across Salt Lake Valley to the Jordan River. The headwaters of Little Cottonwood Creek are in Little Cottonwood Canyon, a glaciated canyon in Wasatch-Cache National Forest and the Wasatch and Uinta Mountains eco-region (Woods and others, 2001). The entire Little Cottonwood Creek drainage basin encompasses $46 \mathrm{mi}^{2}$, ranging in altitude from about 4,490 to 11,500 ft. The Little Cottonwood

Creek urban land-use study area encompasses the Little Cottonwood Creek drainage basin from the canyon mouth to the confluence with the Jordan River (fig. 1). The study area is about $13.3 \mathrm{mi}^{2}$, ranges in altitude from 4,490 to 5,810 ft, and lies in Salt Lake Valley and in the Central Basin and Range eco-region (Woods and others, 2001).

\section{Land Use and Urbanization}

The reach of Little Cottonwood Creek used for the urban land-use study extends across several communities, each of which was established as a separate town site and later grew to include residential areas extending to adjacent community boundaries. These communities were founded soon after pioneer settlement of Salt Lake Valley in 1847 and supported agricultural activities. Following the discovery of gold, silver, copper, and lead in nearby canyons in the 1870 s, ore-refining activities brought an influx of people to these communities. During the mid- to late 1900s, residential land use replaced agriculture as the dominant land-use type in the lower Little Cottonwood Creek drainage basin as the population of Salt Lake Valley expanded.

Land cover upstream from the mouth of Little Cottonwood Canyon is 60 percent forest land and 33 percent rangeland (fig. 3). The watershed in Little Cottonwood Canyon is protected as a drinking water source but receives extensive recreational use. The urbanized part of the Little Cottonwood Creek drainage basin includes that part from the mouth of Little Cottonwood Canyon to the confluence with the Jordan
River. Land use in the valley and urbanized area of the Little Cottonwood Creek drainage basin was remapped for this report. The system of land-use classification used throughout this report is described by Anderson and others (1976).

Residential land use accounts for 52 percent of land use in the urbanized area of the Little Cottonwood Creek drainage basin. Vegetative cover accounts for 21 percent of the land use in the urban drainage, followed by roads and utilities that account for 15 percent. Commercial and municipal structures account for 8 percent, and golf courses, water, and barren ground account for the remaining 3 percent. Low-density residential housing, consisting mostly of single-family dwellings, accounts for 96 percent of the residential land use.

The first legitimate mining operation in Little Cottonwood Canyon was established in 1865 (Calkins, 1943). The ore deposits in Little Cottonwood Canyon yielded principally silver and lead with some copper, gold, and zinc. These ore deposits were formed mainly in shale, limestone, and dolomite. Galena or lead sulfide was the common primary lead mineral of the area. Argentite was found in most of the primary ores and was probably an abundant primary silver mineral. Ore production varied with time because of the nature of the deposits and the scattered control of holdings. The 1870 s were especially productive, when rich deposits were mined.

A number of smelters operated along Little Cottonwood Creek during the 1870s. The Davenport and Flagstaff silver and lead smelters were located at the mouth of Little Cottonwood Canyon (fig. 1) and were operated from 1872 to 1875 . Because of the technology employed during this period of smelter operation, as much as half the lead was lost to slag or emitted from the low stacks. Several other smelters began operating in the 1870s farther downstream, near site 2. The Germania smelter was built in 1872 and operated until 1902, when the Murray Smelter replaced it, operating until 1949. Smelting operations produced a variety of by-products that included arsenic, matte, arsenical speiss, and slag (U.S. Environmental Protection Agency, 1998a). 


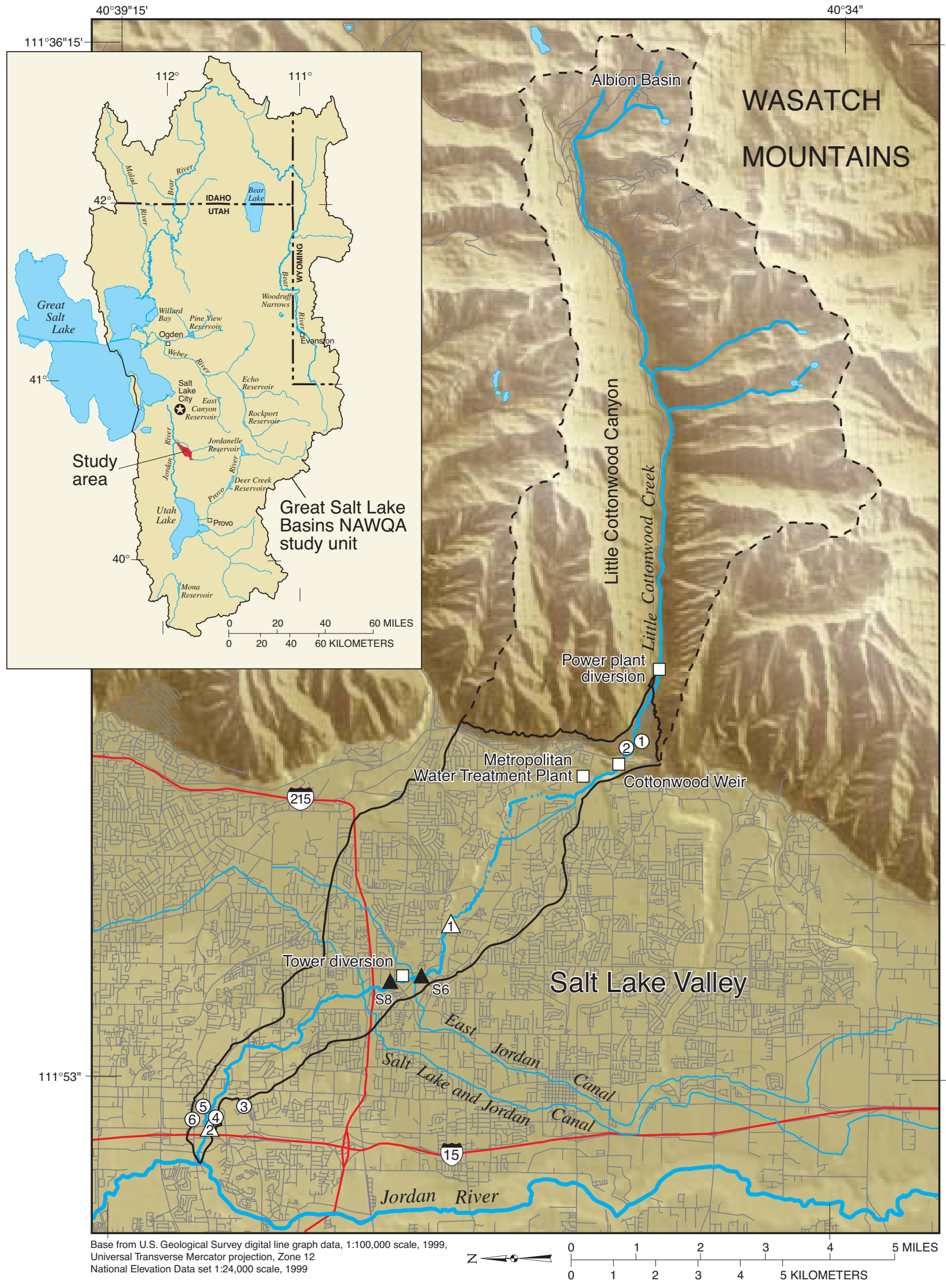

Figure 1. Location of study area, fixed sites, historic smelter sites, and photographs showing area near fixed sites 1 and 2, and headwaters of Little Cottonwood Creek in Albion Basin, near Salt Lake City, Utah. 


\section{EXPLANATION}

Boundary of Little Cottonwood Creek drainage basin

- Urbanized area

....- Non-urban area

1 Fixed site

1 Little Cottonwood Creek at Crestwood Park

2 Little Cottonwood Creek at Jordan River

S6 Synoptic site

$\square$ Hydrologic feature

(2) Historic smelter site-Approximate location

1 Davenport

2 Flagstaff

3 Murray

4 Germania

5 Wasatch silver-lead works

6 Silver

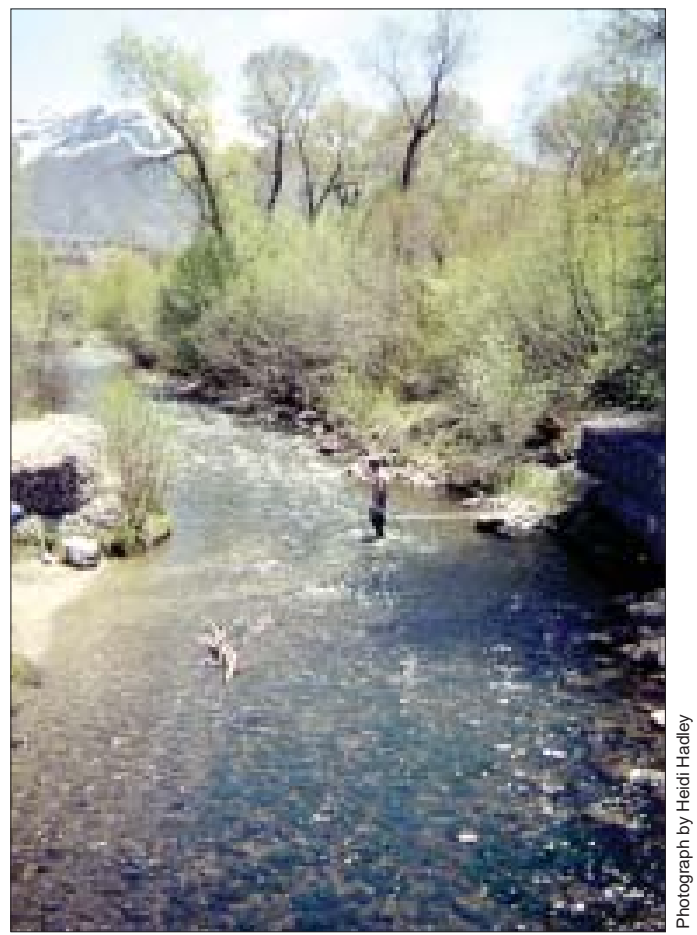

Little Cottonwood Creek, near site 1

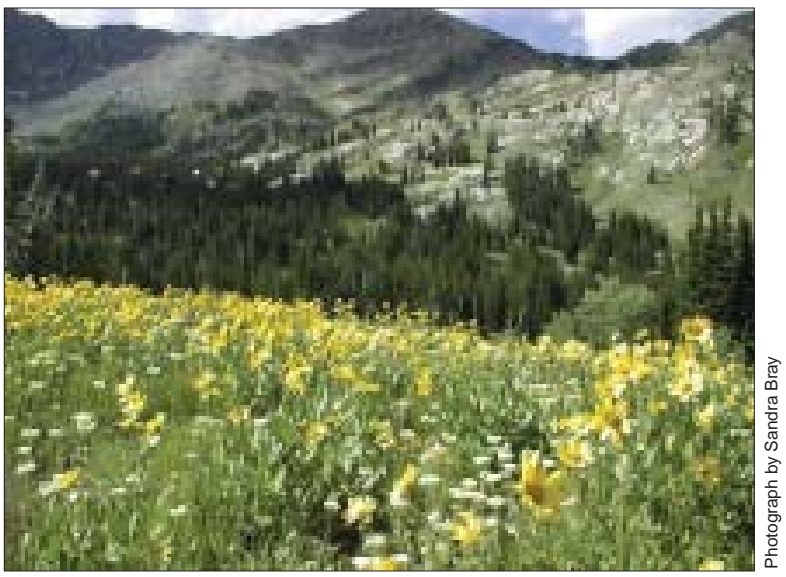

Albion Basin

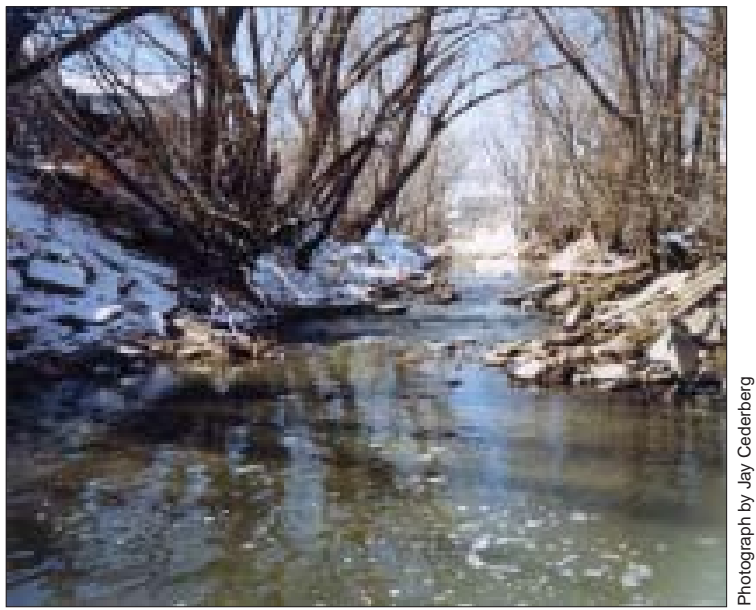

Little Cottonwood Creek, near site 2

Figure 1. Location of study area, fixed sites, historic smelter sites, and photographs showing area near fixed sites 1 and 2, and headwaters of Little Cottonwood Creek in Albion Basin, near Salt Lake City, Utah-Continued. 


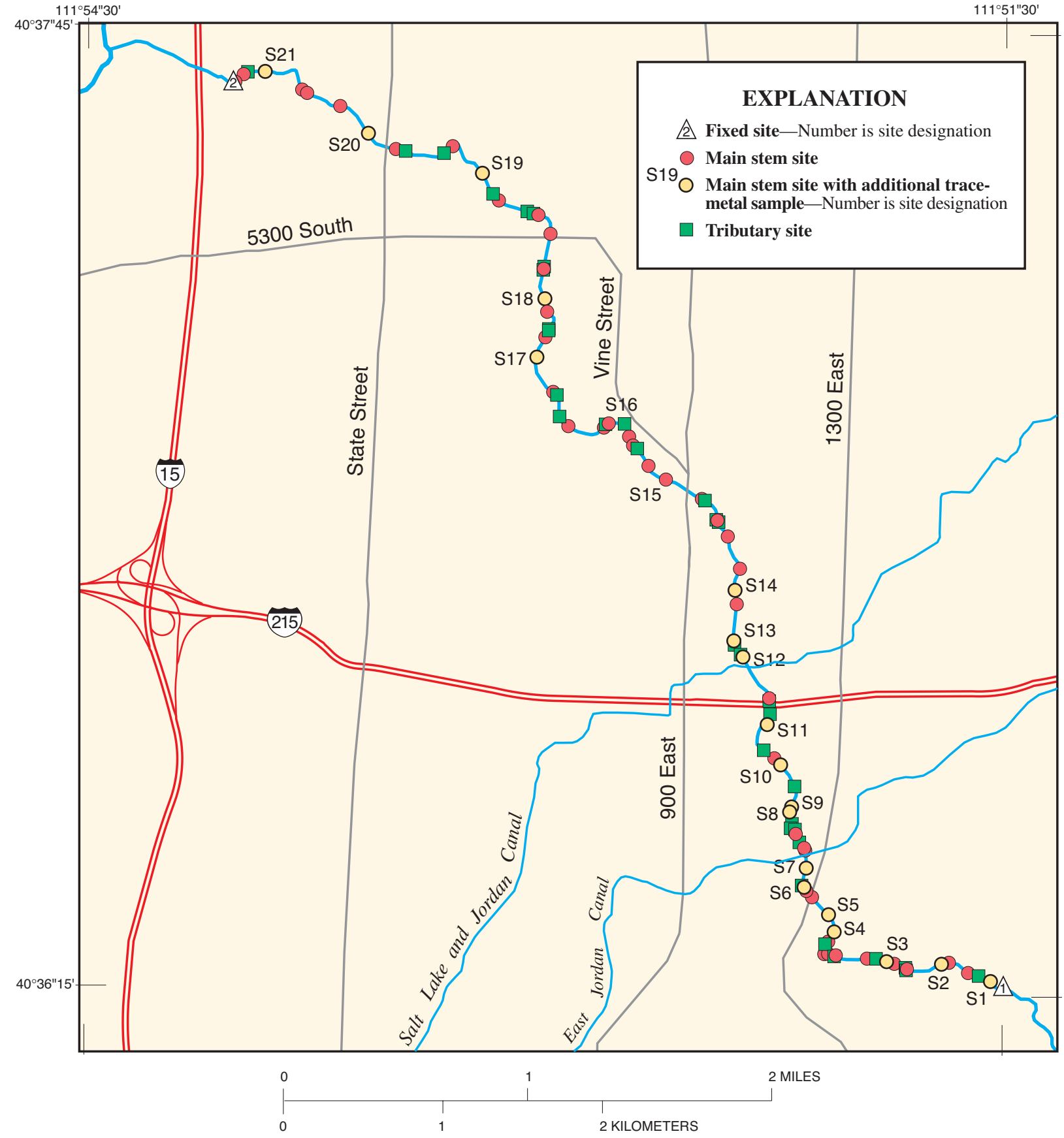

Figure 2. Location of sample sites, Little Cottonwood Creek, near Salt Lake City, Utah, August 31 and September 2, 1999. 


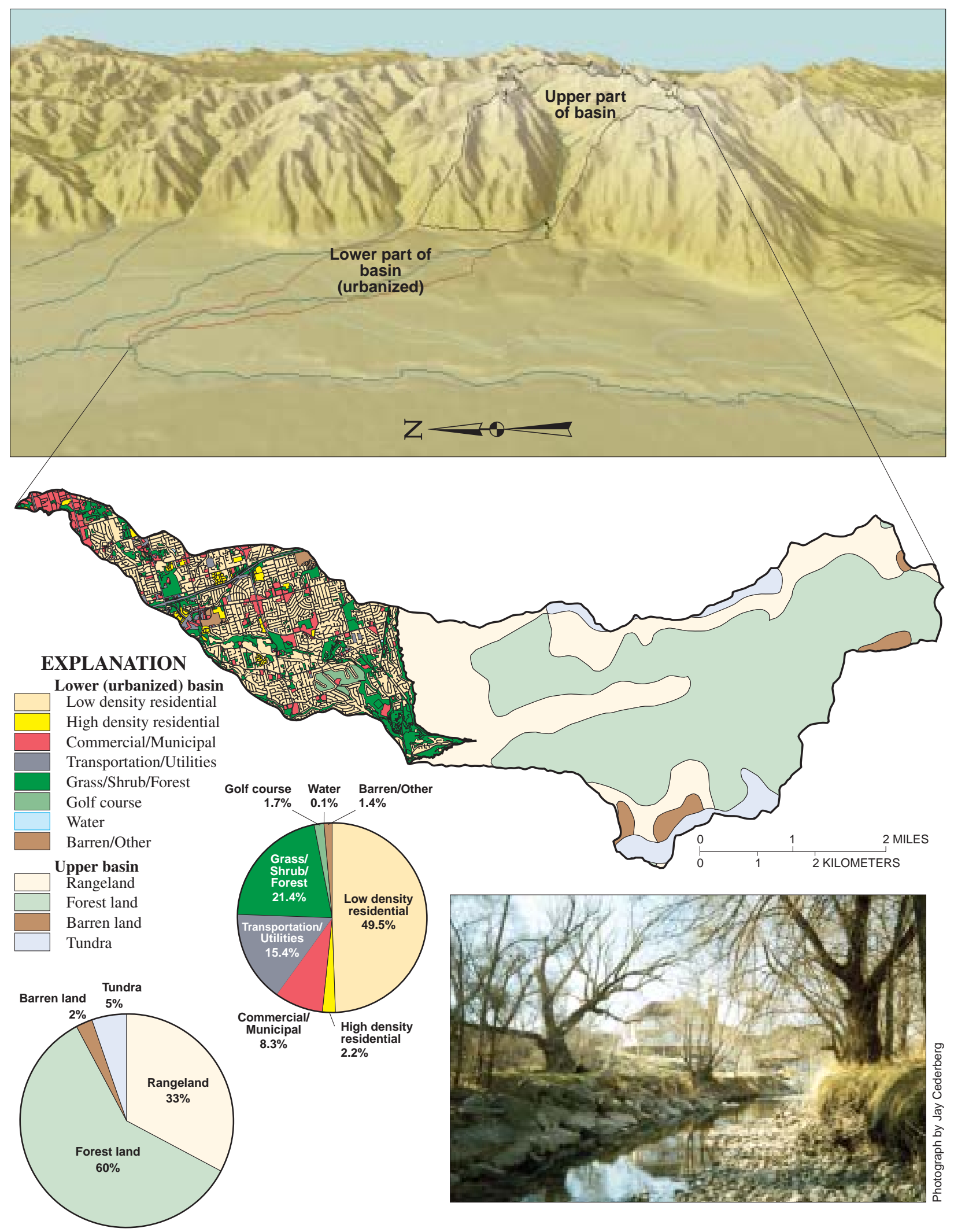

Figure 3. Land use/cover of Little Cottonwood Creek drainage basin, near Salt Lake City, Utah. 
Past mining activities and ore-smelting operations continue to influence the water chemistry of the stream. Mine and smelter tailings in the Little Cottonwood Creek drainage basin can contribute trace metals to the stream. Metals from tailings can be transported by surface runoff and ground-water infiltration to the stream. Metals from fluvial tailings deposits in the stream can be resuspended and dissolved in the stream.

\section{Stream Classification}

The Utah Division of Water Quality classifies water bodies in Utah as to type of water use to protect against controllable pollution (Utah Department of Environmental Quality, 1997). From the headwaters in Albion Basin to the Metropolitan Water Treatment Plant (fig. 1) near the mouth of the canyon, Little Cottonwood Creek is designated for the beneficial uses of treated drinking water (Class 1C), secondary contact recreation (Class 2B), and cold water aquatic-life support (Class 3A). Below the Metropolitan Water Treatment Plant to the confluence with the Jordan River, including the urban land-use study reach, Little Cottonwood Creek is designated for the beneficial uses of secondary contact recreation (Class $2 \mathrm{~B}$ ), cold water aquatic-life support (Class $3 \mathrm{~A}$ ), and agricultural uses (Class 4).

\section{METHODS OF SAMPLE COLLECTION AND DATA ANALYSIS}

Monthly samples were collected at sites 1 and 2 during the 1999 and 2000 water years. Weekly to biweekly samples were collected at site 2 from March 1999 to August 1999. Additional samples were collected at these sites during extreme flow and during synoptic studies. During each site visit, field measurements of specific conductance, water temperature, $\mathrm{pH}$, dissolved oxygen, and alkalinity were made. Samples were analyzed at the USGS National Water Quality Laboratory in Denver, Colorado.

Discrete fixed-interval and most high-flow water samples were obtained for analysis of most constituents by collecting and compositing depthintegrated subsamples at equal-width increments or equal-discharge increments across the stream channel by using either a US DH-81 or a US D-95 sampler (Edwards and Glysson, 1988; Shelton, 1994).
Conditions of low velocity and/or shallow depths required that some samples be collected with a weighted open bottle. Organic carbon samples were collected separately in a baked amber glass bottle by using a weighted sampler at a single midstream vertical (Shelton, 1994). Volatile organic compound (VOC) samples were collected with a specially designed Wildco sampler, into which 40-milliliter (ml) vials were placed directly to collect a sample at a single point in the stream (Shelton, 1997).

Samples were composited and split into equal subsamples with a Teflon cone splitter, except for those samples analyzed for organic carbon and VOCs, which were collected separately. Samples were processed in the field immediately after collection to reduce the chance of chemical or biological alteration. Major cation and anion, dissolved nutrient, and dissolved trace-element samples were filtered through a Gelman capsule filter with 0.45 -micrometer $(\mu \mathrm{m})$ pore size, and pesticide samples were filtered through a baked glass fiber filter with $0.70-\mu \mathrm{m}$ pore size. Suspended and dissolved organic carbon samples were filtered through a silver filter with $0.45-\mu \mathrm{m}$ pore size (Shelton, 1994). Major cation samples were preserved with nitric acid $\left(\mathrm{HNO}_{3}\right)$, whole water nutrient samples were chilled or preserved with sulfuric acid $\left(\mathrm{H}_{2} \mathrm{SO}_{4}\right)$, VOC samples were preserved with concentrated hydrochloric acid. The equipment was cleaned between sites as described in Shelton $(1994,1997)$.

The minimum reporting level (MRL) is the smallest measured concentration of a constituent that may be reliably reported when using a given analytical method. Concentrations are reported as less than the MRL for samples in which the analyte either was not detected or was detected at a concentration less than the MRL. Analytes that are detected at concentrations between the long-term method detection level and MRL are estimated. Estimated concentrations are noted with a remark code of "e." These data should be used with the understanding that their uncertainty is greater than that of data reported without the "e" remark code.

Nine water samples from site 1 and 42 water samples from site 2 were analyzed for pesticides by using gas chromatography/mass spectrometry (GC/MS). Four water samples from site 1 and 24 water samples from site 2 were analyzed for pesticides by using high-performance liquid chromatography/mass spectrometry (HPLC/MS). The HPLC/MS method was a custom method being validated at the USGS National Water-Quality Laboratory concurrently with analysis 
of water samples collected for this study. The HPLC/MS method was still being proven at the time of sample analysis and data from these analyses will remain provisional. Pesticides detected in water samples analyzed by HPLC/MS are reported; however, no concentrations or descriptive statistics associated with detected analytes are reported. Most of the samples analyzed by HPLC/MS were held for an extended period beyond the normal limit of 4 days. This may have resulted in degradation of some compounds initially present in the water samples to a concentration below the method reporting level.

The MRL of an analyte can be the largest influence on the detection frequency of that analyte. A common reporting limit of $0.01 \mu \mathrm{g} / \mathrm{L}$ was used to compare the detection frequencies of pesticides with different MRLs. Pesticide frequency analysis censored detections less than $0.01 \mu \mathrm{g} / \mathrm{L}$, resulting in a slight loss of detection information; however, with a common reporting limit, a more uniform comparison of detection frequencies is possible. Pesticide data, at the original MRL, were used in other statistical analyses.

The same method was applied to VOC data by using a common reporting limit of $0.05 \mu \mathrm{g} / \mathrm{L}$. Estimated values were included in all data analysis.

Constituent loads and concentrations in the study reach, associated with a storm on April 14, 2000, were estimated by using discharge calculated from stage records and constituent concentrations from storm samples. Load calculations were based on the midinterval method described in Techniques of WaterResources Investigations of the United States Geological Survey, Book 3, Chapter C3 (Porterfield, 1972). Concentrations associated with the beginning and ending point of the storm hydrograph were estimated from adjacent samples and used for calculating loads associated with the first and last interval of the storm hydrograph.

\section{HYDROLOGY}

The hydrology of Little Cottonwood Creek is typical of that of many urban streams along the Wasatch Front and in the Intermountain West. A system of diversions for withdrawal of irrigation water began to be developed on many Wasatch Front streams soon after settlers arrived in Salt Lake Valley in 1847. As the population of the Wasatch Front increased, more of the water in valley streams was needed for drinking and domestic purposes. To meet domestic needs, water is withdrawn from several Wasatch Front streams, including Little Cottonwood Creek, as they emerge from headwater canyons and enter Salt Lake Valley. The water needs of irrigators downstream from the canyon mouths are satisfied with water diverted out of the Jordan River and transported across the valley in a system of canals. Some of the water from the Jordan River is imported to the urbanized reach of Little Cottonwood Creek. This water-distribution system continues to be monitored and updated, and the resulting hydrologic system is highly variable and complex.

\section{Stream Characteristics}

In the vicinity of site 1 on Little Cottonwood Creek, the stream gradient is fairly steep, about 2 percent. Cobbles and boulders are the dominant substrates with riffles and runs the dominant features. The stream gradient is gentler in the vicinity of site 2 , less than 0.2 percent. Gravel and sand are the dominant substrates and pools are the dominant feature. Because of the nature of the substrates, an extensive hyporheic zone exists in much of the urban reach of Little Cottonwood Creek. The stream can be further characterized by extensive channelization and modification by structures such as diversion dams and head gates. Many sections of the stream are channeled in concrete or rip-rap to facilitate rapid downstream movement of snowmelt and storm flow.

\section{Streamflow Components}

Because of diversions of water out of Little Cottonwood Creek above the urban reach and imports to and diversions from the urban reach, natural streamflow conditions seldom occur in the urban reach between sites 1 and 2. A small hydroelectric plant (fig. 1) withdraws water from Little Cottonwood Creek through a 52-in.-diameter aqueduct about $2 \mathrm{mi}$ upstream from the mouth of Little Cottonwood Canyon. The water is then diverted to the Metropolitan Water Treatment Plant for drinking water supplies. During low- to moderate-flow conditions, this diversion results in withdrawal of all the water originating in the canyon before it reaches the valley 
and the urbanized reach. Snowmelt runoff and runoff from some larger storms exceed the water needs of upstream users, and excess water from the upper part of the basin reaches the valley and urbanized reach of the stream during these events. For several months during the spring and early summer, snowmelt runoff from Little Cottonwood Canyon makes up most of the flow in the valley and urbanized reach of the stream that includes sites 1 and 2 .

During times when most of the water is diverted from the canyon, the sources of water for Little Cottonwood Creek at site 1 are localized ground-water inflow or sub-surface drainage and surface runoff from the urban area. Because of withdrawals, sections of Little Cottonwood Creek immediately upstream from site 1 and some sections downstream from site 1 are completely dewatered for extended periods each year. These sections are shown as intermittent in figure 1 . During storms, storm drains throughout the urban study reach between sites 1 and 2 provide the major source of water to the stream.

Streamflow at site 2 may contain imported water from the Jordan River through the East Jordan Canal during about April 15 to September 15. Water is imported through this route to many parts of Salt Lake Valley. During storms or periods of low water use, water from the East Jordan Canal may spill and enter Little Cottonwood Creek at the Tower diversion (fig. 1) between sites 1 and 2 . The water imported from the Jordan River has its source in a complex mix of landuse types.

Substantial ground-water inflow contributions to streamflow between sites 1 and 2 were identified by using a synoptic approach and lithium-bromide tracer. The tracer-injection study was done by using methods and calculations described in Broshears and others (1993). The tracer was injected in the lower $4.5 \mathrm{mi}$ of the reach between sites 1 and 2 on August 31, 1999. The tracer was injected in the upper $1.2 \mathrm{mi}$ of the reach between sites 1 and 2 on September 2, 1999. Discharge in the gaining stream was determined by measuring the dilution of the lithium-bromide tracer as it moved downstream from the point of injection. Dilution of the tracer may be attributed to ground-water inflow to the stream if no surface inflows are evident. Samples were collected at 97 locations between sites 1 and 2. Fiftyeight sites were along Little Cottonwood Creek and 39 were at surface-water inflows to the creek. Streamflow for Little Cottonwood Creek between sites 1 and 2 is shown in figure 4. Estimated ground-water inflow accounted for about 10 to 49 percent of total streamflow at the time of the synoptic study. The ground-water component of total streamflow varied little in the 4.4-mi reach below site 1 and then approximately doubled, from about $5 \mathrm{ft}^{3} / \mathrm{s}$ to about 10 $\mathrm{ft}^{3} / \mathrm{s}$ in the $1.3-\mathrm{mi}$ reach above site 2 .

Peak runoff is associated with either spring snowmelt from April through June, or rain occurring during July through October. Both types of runoff can result in large diurnal variations in streamflow.

Rainstorms in late spring through fall are often of short duration and are associated with rapid increases and subsequent decreases in streamflow.

Average annual snowfall was 516 in. during 1948-2000 in Little Cottonwood Canyon and 94 in. in the urban area of the Little Cottonwood Creek drainage (measured at the Cottonwood Weir). Mild temperatures in the urban area often result in snowmelt runoff to Little Cottonwood Creek during or shortly after a winter storm; however, runoff associated with winter storms typically occurs throughout a longer period and with much lower peak flows than spring and summer storms.

Daily mean streamflow for water years 19992000 ranged from 0.03 to $359 \mathrm{ft}^{3} / \mathrm{s}$ at site 1 and from 1.3 to $357 \mathrm{ft}^{3} / \mathrm{s}$ at site 2 (fig. 5). Annual runoff at site 1 was 24,750 acre-ft during 1999 and 10,640 acre-ft during 2000. About 95 percent of the runoff resulted from snowmelt during April to July. Annual runoff at site 2 was 32,730 acre-ft during 1999 and 15,310 acre$\mathrm{ft}$ during 2000, and about 85 percent of the runoff was from snowmelt during April to July (fig. 6). Total annual runoff at both sites during the 2000 water year was less than half of total annual runoff for the 1999 water year, with the runoff peak occurring a month earlier in 2000 than in 1999.

\section{WATER QUALITY}

Composition of water in a stream results from chemical reactions in the water, from processes that transfer constituents between the water and other parts of the biogeochemical system, and from fluxes into and out of the system (Stumm and Morgan, 1996).

Temporal variations in the chemistry of Little Cottonwood Creek may occur as water is diverted into and out of the hydrologic system, chemical constituents enter the system from the urban environment, or 


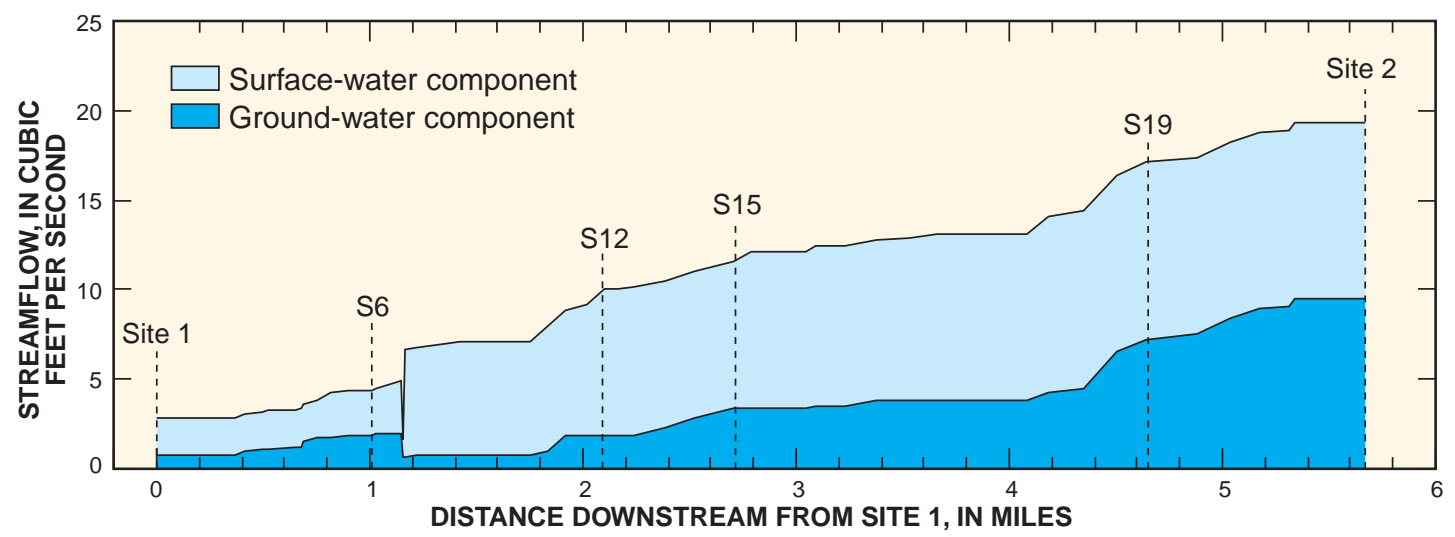

Figure 4. Streamflow between sites 1 and 2, Little Cottonwood Creek, near Salt Lake City, Utah, August 31 and September 2, 1999.

biological and physical processes alter solute concentrations. Data obtained from the chemical analysis of water samples collected at site 1 near the canyon mouth and site 2 near the confluence with the Jordan River were used to evaluate the effects of urbanization on stream chemistry.

\section{Properties}

Physical and chemical properties including specific conductance, $\mathrm{pH}$, water temperature, dissolved oxygen (DO), and alkalinity were measured in the field with each sample (table 1). Continuous specificconductance and water-temperature measurements were made at sites 1 and 2. Daily values for specific conductance and water temperature were calculated from values measured at 15-minute intervals.

Daily mean specific-conductance values at site 1 ranged from 99 to $5,290 \mu \mathrm{S} / \mathrm{cm}$ (fig. 7), and instantaneous specific-conductance values ranged from 72 to $9,360 \mu \mathrm{S} / \mathrm{cm}$. daily mean specific-conductance values at site 2 ranged from 72 to $7,300 \mu \mathrm{S} / \mathrm{cm}$ (fig. 6), and instantaneous specific-conductance values ranged from 141 to $15,100 \mu \mathrm{S} / \mathrm{cm}$. Most winter storms resulted in specific-conductance values exceeding $2,000 \mu \mathrm{S} / \mathrm{cm}$. Spring snowmelt and summer storms generally lowered specific-conductance values to below $250 \mu \mathrm{S} / \mathrm{cm}$ at site 1 and below $700 \mu \mathrm{S} / \mathrm{cm}$ at site 2.

Well-defined relations among specificconductance values and dissolved-solids concentrations characterize most surface water (Hem, 1992). Evaluation of data collected at sites 1 and 2 indicates that specific conductance can be used to calculate concentrations of some other constituents, such as chloride and sodium, which correlate well with specific conductance at sites 1 and 2 (fig. 8).

The $\mathrm{pH}$ at site 1 ranged from 7.5 to 8.6 with a median value of 8.2 (fig. 9). At site $2, \mathrm{pH}$ ranged from 7.6 to 8.4 with a median value of 8.1. Larger amounts of aquatic vegetation and lower turbidity were observed at site 1 than at site 2 . Because water samples at site 1 were generally less buffered than at site 2 , a higher level of photosynthetic activity of the aquatic vegetation, removing and releasing $\mathrm{CO}_{2}$ and hydrogen ions, may, in part, account for the larger $\mathrm{pH}$ range at site 1 . The range of $\mathrm{pH}$ values measured at both sites falls within established national and Utah criteria $(\mathrm{pH}$ range of 6.5 - 9.0) for aquatic organisms.

Because DO measurements most often were taken at site 1 during the early afternoon and at site 2 during mid- to late morning, diurnal changes in DO were not picked up by measurements at the fixed sites. Dissolved-oxygen concentrations ranged from 8.4 to $14.1 \mathrm{mg} / \mathrm{L}$ at site 1 and from 7.3 to $11.4 \mathrm{mg} / \mathrm{L}$ at site 2 . Dissolved-oxygen measurements were most often near or above saturation at site 1 (fig. 9), probably as a result of photosynthesis of aquatic vegetation. Sags in nighttime DO concentrations at sites 1 and 2 may have occurred during the study as a result of plant respiration. More data collection through diel (24-hour) oxygen studies is needed to determine whether low DO concentrations occur and if they are harmful to the environment in Little Cottonwood Creek. Dissolvedoxygen measurements were mostly near or below saturation at site 2, possibly as a result of the time of day that samples were collected or because of increased loads of oxygen-demanding substances and organic carbon. In a 1981 study of DO in the 


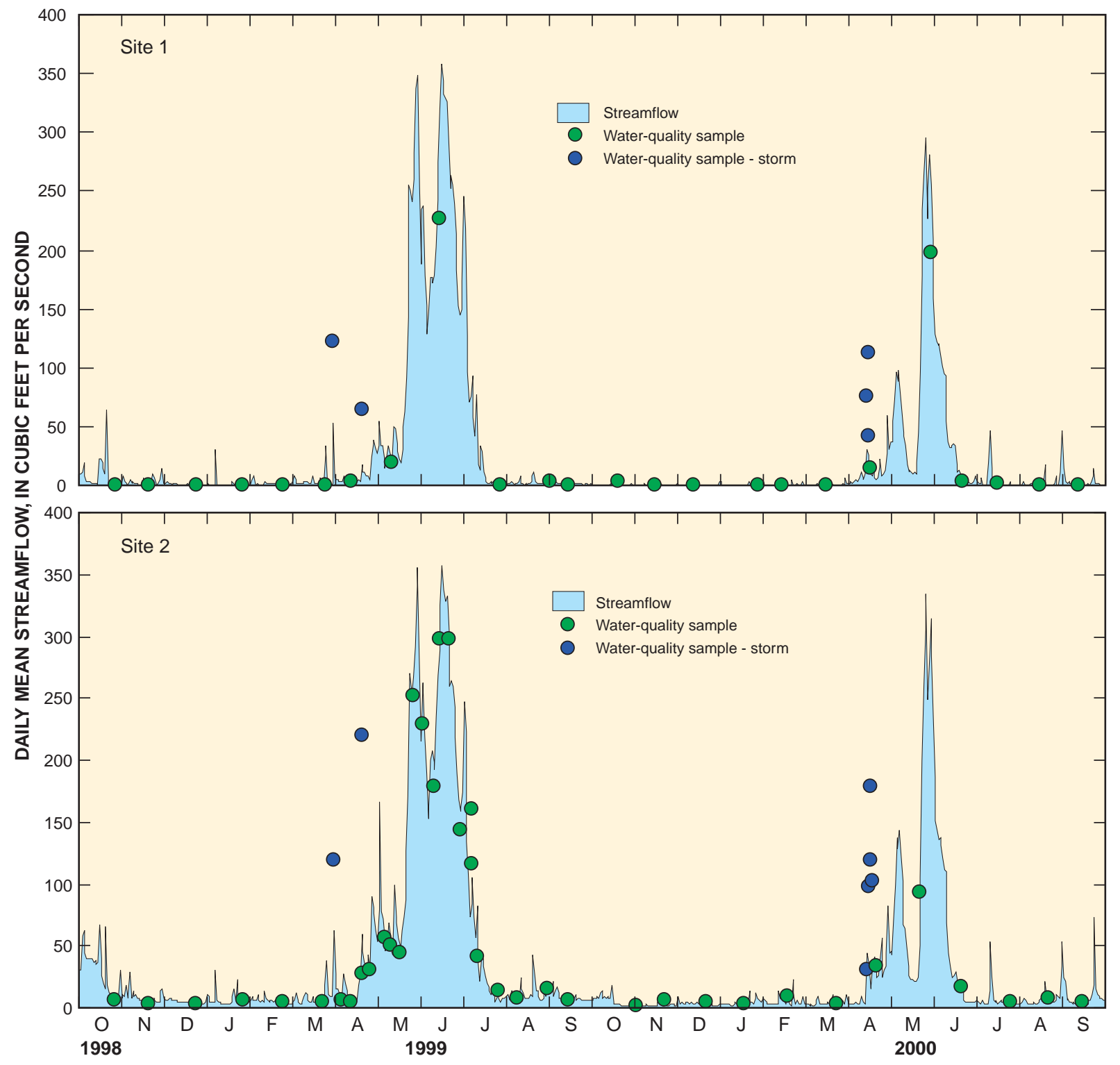

Figure 5. Daily mean streamflow and temporal distribution of water-quality samples at sites 1 and 2 on Little Cottonwood Creek, near Salt Lake City, Utah. 


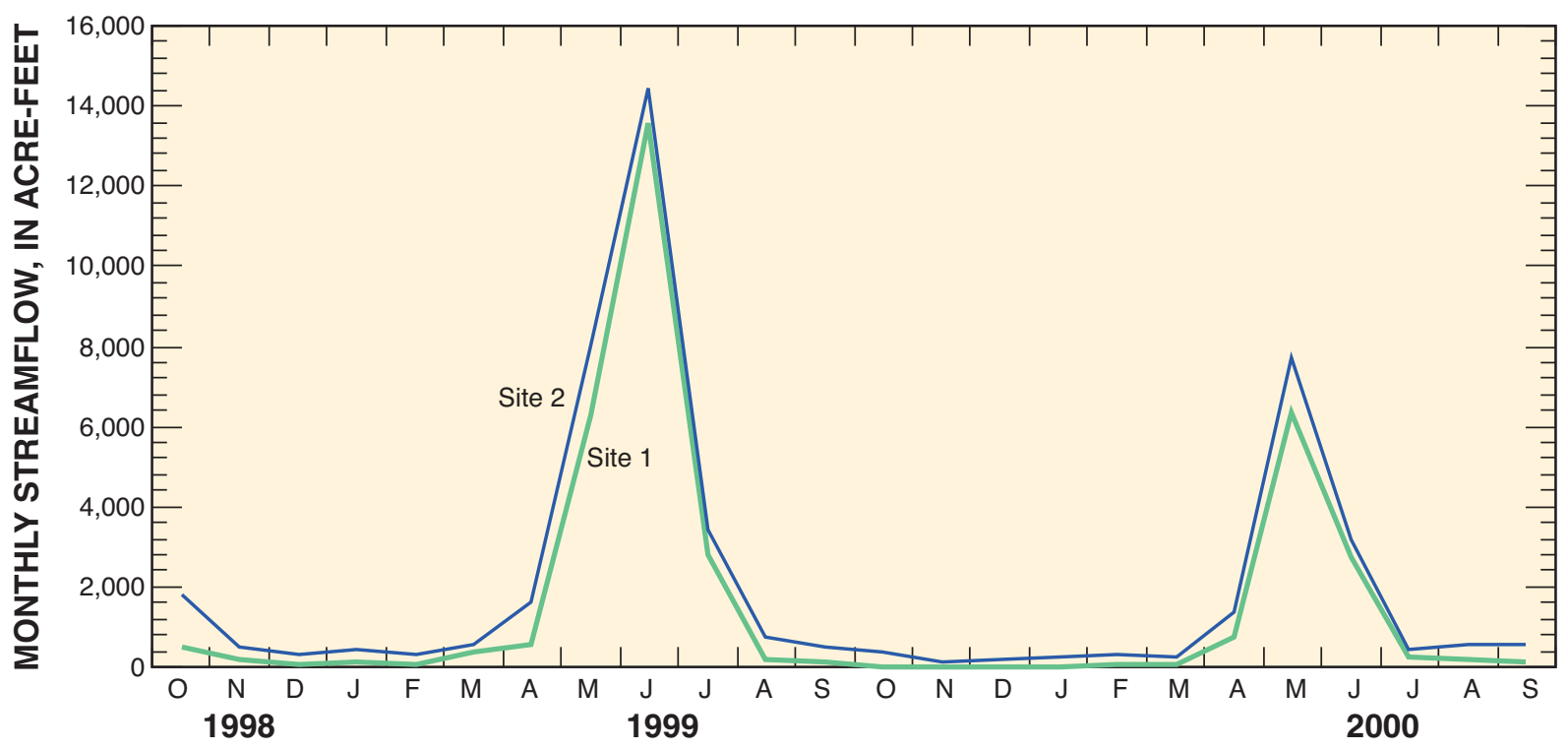

Figure 6. Monthly streamflow at sites 1 and 2 on Little Cottonwood Creek, near Salt Lake City, Utah.

Jordan River, Little Cottonwood Creek was determined to be a major contributor of oxygen-demanding substances during non-storm periods (Stephens, 1984).

Cumulative frequency curves of daily mean water temperature were developed for sites 1 and 2 by using daily mean values calculated from fixed interval (15-minute) samples (fig. 10). Because of short periods of missing data at both sites, these graphs represent cumulative distribution and not probability. The 50percent frequency point represents the median daily water temperature. The median daily water temperature for the study period was $7.6^{\circ} \mathrm{C}$ at site 1 and $10.2^{\circ} \mathrm{C}$ at site 2 . Higher flows and cooler air temperatures resulted in a smaller annual range and slightly lower median value for daily mean water temperature at both sites in water year 1999 than in 2000. Water temperature ranged from 0 to $29.6^{\circ} \mathrm{C}$ at site 1 and from 0.1 to $26.2^{\circ} \mathrm{C}$ at site 2 during this study. Winter water temperatures at site 1 are often low enough to result in ice formation. Urban and ground-water inflows between sites 1 and 2 generally prevent ice formation at site 2.

Water temperature for a typical spring and summer day (fig. 10) illustrate the diurnal water temperature change at sites 1 and 2 . The range of the diurnal variation can be greater at site 1 than at site 2 . This may be because of the ground-water inflow between sites 1 and 2, more canopy cover and less solar heating in the reach near site 2, and lower streamflow with shallower depths at site 1 . The Utah Aquatic Criterion for maximum water temperature in Class 3A streams is $20^{\circ} \mathrm{C}$ (Utah Department of Environmental Quality, 1997). This criterion was exceeded on many days at both sites.

\section{Major lons}

Variations of dissolved-solids concentration and major inorganic chemical composition of water at sites 1 and 2 on Little Cottonwood Creek generally are associated with seasonal snowmelt runoff, winter storm runoff, spring storms, and diversions and imports of irrigation water. During October to April, when diversions and imports are minimal or non-existent, the water quality of the base flow at site 1 is characteristic of that of ground water entering the reach above the site. At site 1 most of the ground-water inflow is from the perched shallow aquifer that is hydraulically connected to the stream. Base flow at site 2 is generally composed of surface runoff from the urban area and ground-water discharge from the shallow unconfined aquifer. 
Table 1. Minimum reporting level of parameters and constituents measured at fixed sites on Little Cottonwood Creek, near Salt Lake City, Utah [mg/L, milligrams per liter; $\mu \mathrm{g} / \mathrm{L}$, micrograms per liter]

\begin{tabular}{|c|c|c|c|}
\hline Activity & Parameter or constituent & $\begin{array}{c}\text { Minimum reporting } \\
\text { level }\end{array}$ & Unit \\
\hline
\end{tabular}

Field measurement

Physical properties
Discharge

Specific conductance

$\mathrm{pH}$

Water temperature

Dissolved oxygen

Alkalinity
.01

1

.1

.1

.1

1
Cubic foot per second

Microsiemen per centimeter at 25 degrees Celsius

Standard unit

Degree Celsius

$\mathrm{mg} / \mathrm{L}$

$\mathrm{mg} / \mathrm{L}$

Laboratory analyses

Calcium, dissolved

Chloride, dissolved

Dissolved solids, residue on evaporation

Fluoride, dissolved

Magnesium, dissolved

Manganese, dissolved

Potassium, dissolved

Silica, dissolved

Sodium, dissolved

Sulfate, dissolved

Nitrogen, ammonia, dissolved

Nitrogen, nitrite, dissolved

Nitrogen, nitrite plus nitrate, dissolved

Nitrogen, organic plus ammonia, dissolved

Nitrogen, organic plus ammonia, total

Phosphorus, orthophosphate, dissolved

Phosphorus, dissolved

Phosphorus, total

Dissolved

Suspended

Aluminum, dissolved

Antimony, dissolved

Arsenic, dissolved

Barium, dissolved

Beryllium, dissolved

Boron, dissolved

Cadmium, dissolved

Chromium, dissolved

Cobalt, dissolved

Copper, dissolved

Iron, dissolved

Lead, dissolved

Lithium, dissolved

Molybdenum, dissolved

Nickel, dissolved

Selenium, dissolved

Silver, dissolved
Major ions

$\begin{array}{cc}.02 & \mathrm{mg} / \mathrm{L} \\ .1 \text { and } .29 & \mathrm{mg} / \mathrm{L} \\ 10 & \mathrm{mg} / \mathrm{L} \\ .1 & \mathrm{mg} / \mathrm{L} \\ .004 \text { and } .014 & \mathrm{mg} / \mathrm{L} \\ 3.0 \text { and } 2.2 & \mu \mathrm{g} / \mathrm{L} \\ .1 \text { and } .24 & \mathrm{mg} / \mathrm{L} \\ .05 \text { and } .09 & \mathrm{mg} / \mathrm{L} \\ .06 \text { and } .09 & \mathrm{mg} / \mathrm{L} \\ .1 \text { and } .31 & \mathrm{mg} / \mathrm{L}\end{array}$

Nutrients

$\begin{array}{cc}.02 & \mathrm{mg} / \mathrm{L} \\ .01 & \mathrm{mg} / \mathrm{L} \\ .05 & \mathrm{mg} / \mathrm{L} \\ .1 & \mathrm{mg} / \mathrm{L} \\ .1 & \mathrm{mg} / \mathrm{L} \\ .01 & \mathrm{mg} / \mathrm{L} \\ .004 \text { and } .008 & \mathrm{mg} / \mathrm{L} \\ .004 \text { and } .006 & \mathrm{mg} / \mathrm{L}\end{array}$

Organic carbon

.1 and $.33 \quad \mathrm{mg} / \mathrm{L}$

.1 and $.2 \quad \mathrm{mg} / \mathrm{L}$

Trace elements

$\begin{array}{ll}1 & \mu \mathrm{g} / \mathrm{L} \\ 1 & \mu \mathrm{g} / \mathrm{L} \\ 1 \text { and } 2 & \mu \mathrm{g} / \mathrm{L} \\ 1 & \mu \mathrm{g} / \mathrm{L} \\ 1 & \mu \mathrm{g} / \mathrm{L} \\ 16 & \mu \mathrm{g} / \mathrm{L} \\ 1 & \mu \mathrm{g} / \mathrm{L} \\ 1 \text { and } .8 & \mu \mathrm{g} / \mathrm{L} \\ 1 & \mu \mathrm{g} / \mathrm{L} \\ 1 & \mu \mathrm{g} / \mathrm{L} \\ 10 & \mu \mathrm{g} / \mathrm{L} \\ 1 & \mu \mathrm{g} / \mathrm{L} \\ 1 & \mu \mathrm{g} / \mathrm{L} \\ 1 & \mu \mathrm{g} / \mathrm{L} \\ 1 & \mu \mathrm{g} / \mathrm{L} \\ 1 \text { and } 2.4 & \mu \mathrm{g} / \mathrm{L} \\ 1 & \mu \mathrm{g} / \mathrm{L}\end{array}$


Table 1. Minimum reporting level of parameters and constituents measured at fixed sites on Little Cottonwood Creek, near Salt Lake City, UtahContinued

\begin{tabular}{|c|c|c|c|}
\hline Activity & Parameter or constituent & $\begin{array}{c}\text { Minimum reporting } \\
\text { level }\end{array}$ & Unit \\
\hline \multicolumn{4}{|c|}{ Trace elements-Continued } \\
\hline & Strontium, dissolved & 1 & $\mu \mathrm{g} / \mathrm{L}$ \\
\hline & Thallium, dissolved & .9 & $\mu \mathrm{g} / \mathrm{L}$ \\
\hline & Uranium, dissolved & 1 & $\mu \mathrm{g} / \mathrm{L}$ \\
\hline & Vanadium, dissolved & 1 & $\mu \mathrm{g} / \mathrm{L}$ \\
\hline & Zinc, dissolved & 1 & $\mu \mathrm{g} / \mathrm{L}$ \\
\hline \multicolumn{4}{|c|}{ Sediment } \\
\hline & Suspended & 1 & $\mathrm{mg} / \mathrm{L}$ \\
\hline \multicolumn{4}{|l|}{ Datalogger } \\
\hline & Streamflow, 15-minute interval & .01 & Cubic foot per second \\
\hline & Specific conductance, 15-minute interval & 1 & Microsiemen per centimeter at 25 degrees Celsius \\
\hline & Water temperature, 15 -minute interval & .1 & Degree Celsius \\
\hline
\end{tabular}

Water samples typical of low flow conditions were collected on November 19, 1999, at sites 1 and 2 (fig. 11). The dissolved-solids concentration at site 1 was $293 \mathrm{mg} / \mathrm{L}$, with calcium and bicarbonate as the predominant ions. At site 2 the dissolved-solids concentration was $708 \mathrm{mg} / \mathrm{L}$ and the predominant ions were calcium, sodium, chloride, and bicarbonate. In the reach between sites 1 and 2, water from surface drains and the shallow unconfined aquifer is a higher percentage of the flow. Water from surface drains and the shallow unconfined aquifer typically contains higher concentrations of dissolved solids than does ground water from the upgradient perched aquifers.

During winter low-flow conditions, storm runoff often affects the water quality in the canyon and the valley reaches because of sodium chloride used for road salting. Samples collected on January 25, 1999, at sites 1 and 2 represent the effects of road salting after a winter snowstorm (fig. 11). At site 1 the dissolvedsolids concentration was $1,280 \mathrm{mg} / \mathrm{L}$ and the predominant ions were sodium and chloride. At site 2 the concentration was $882 \mathrm{mg} / \mathrm{L}$ and the predominant ions also were sodium and chloride. The higher concentration occurred at site 1 because the storm runoff made up a greater percentage of the total flow there than at site 2 , where there are larger contributions of relatively dilute ground water.

On April 20, 1999, samples were collected at sites 1 and 2 during a rainstorm. The dissolved-solids concentration was $118 \mathrm{mg} / \mathrm{L}$ at site 1 and $262 \mathrm{mg} / \mathrm{L}$ at site 2. Sodium and chloride were the dominant ions even though the concentrations were quite low relative to concentrations measured during winter storms. The high concentration of sodium and chloride ions is most likely residual from winter road salting.

On June 15, 1999, samples were collected during snowmelt runoff. The dissolved-solids concentration was $80 \mathrm{mg} / \mathrm{L}$ at site 1 and $171 \mathrm{mg} / \mathrm{L}$ at site 2 . At site 1 the dominant ions were calcium and bicarbonate, and at site 2 the dominant ions were mixed and included sodium, calcium, chloride, and bicarbonate ions.

During the irrigation season and periods of low flow, intermittent inflow from the Jordan and Salt Lake Canal and East Jordan Canal (fig. 1) can affect the flow and chemical composition of Little Cottonwood Creek below the inflow. The canals are operated from about April 15 to October 15. During storms, or when there is excess water that is not being used for irrigation, some water from the canals may also enter the stream. Not all of the water that enters Little Cottonwood Creek from the canals will reach site 2 because of diversions between the point of inflow and site 2. Samples collected at site 1 on September 2, 1999, and at site 2 on August 31, 1999, represent a period when flow from the East Jordan Canal was entering the stream. The dissolved-solids concentration was $140 \mathrm{mg} / \mathrm{L}$ at site 1 and $472 \mathrm{mg} / \mathrm{L}$ at site 2 . Calcium and bicarbonate were the dominant ions at site 1 and sodium and chloride were dominant at site 2 during the period of inflow from the canal. During this period a substantial amount of streamflow in the East Jordan Canal was probably storm runoff. The concentration of dissolved solids normally measured at site 2 during base-flow conditions was reduced through dilution by inflow from the canal, but the canal flow contains other constituents that deteriorate the water quality at site 2 . 


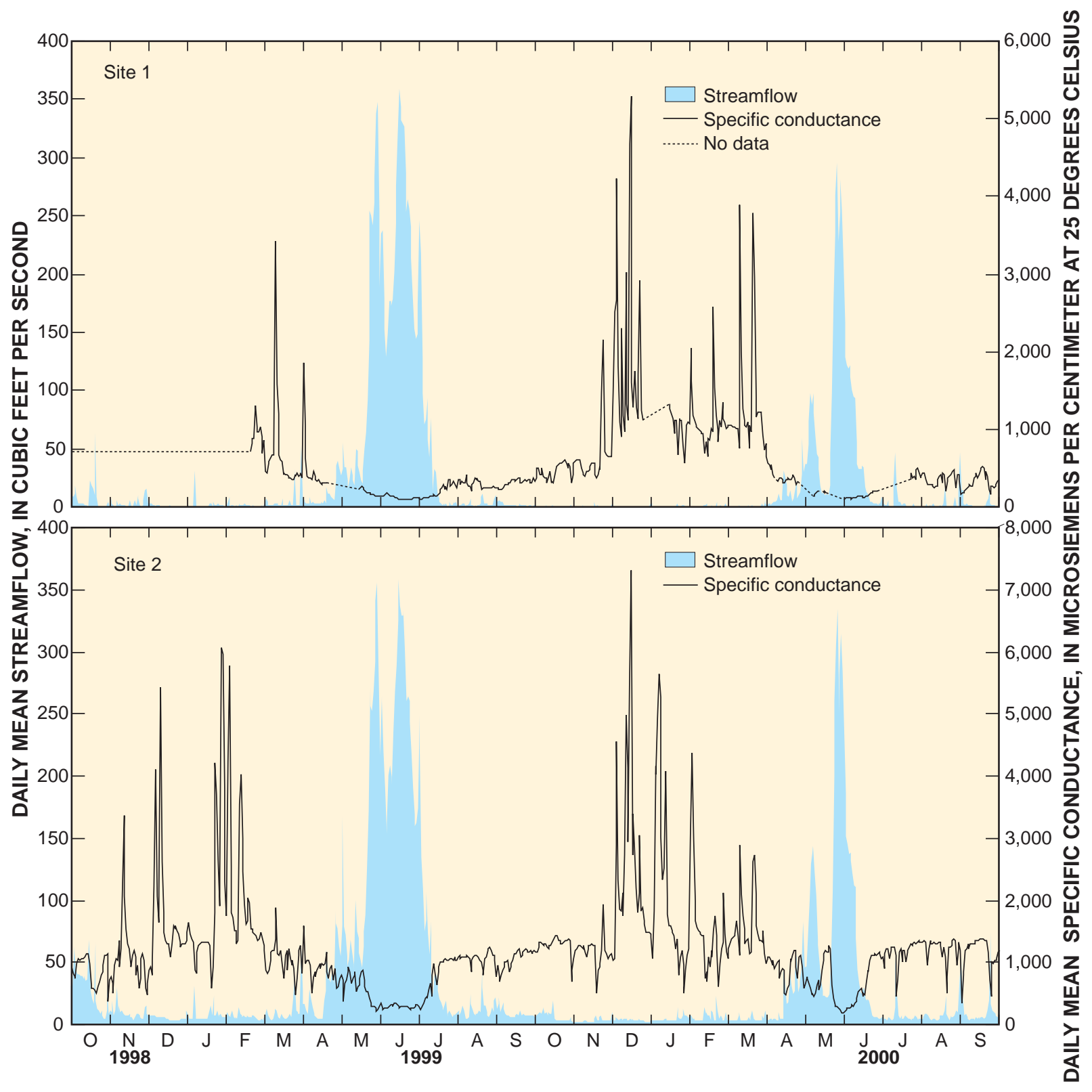

Figure 7. Daily mean streamflow and specific conductance at sites 1 and 2 on Little Cottonwood Creek, near Salt Lake City, Utah. 

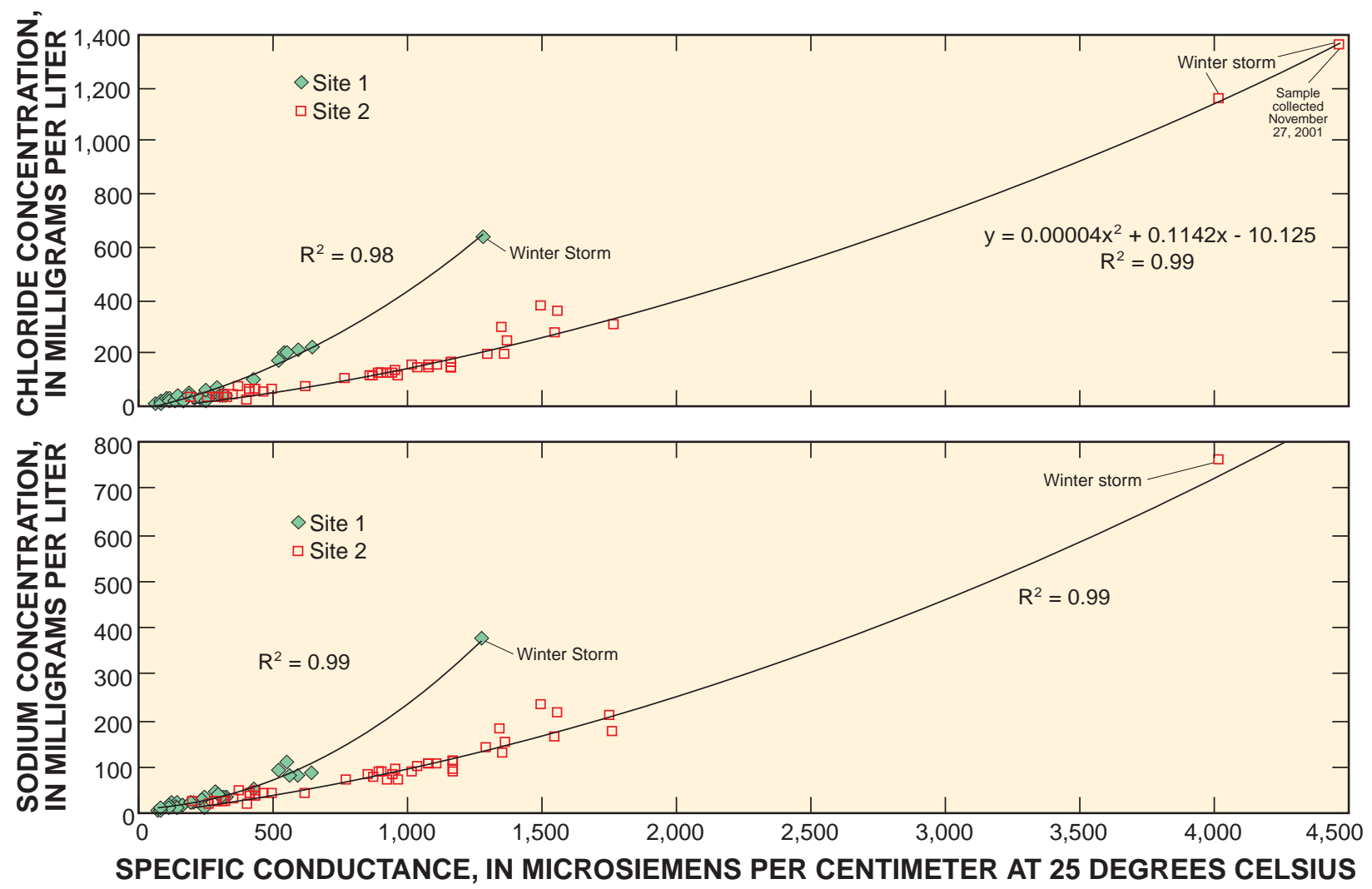

Figure 8. Relation of chloride and sodium concentration to specific conductance at sites 1 and 2 on Little Cottonwood Creek, near Salt Lake City, Utah.
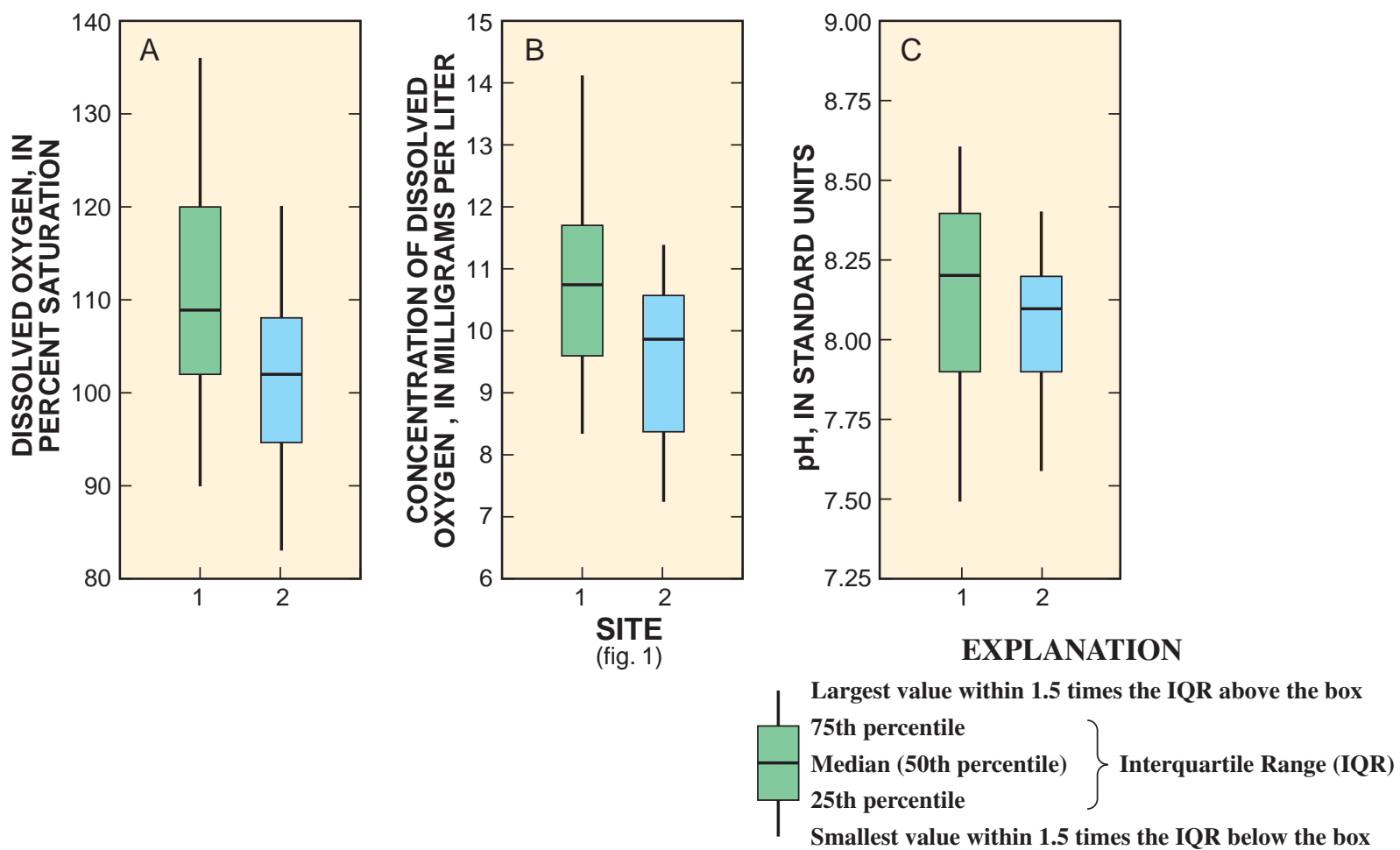

Figure 9. Boxplots showing $(A)$ dissolved oxygen, in percent saturation, (B) dissolved-oxygen concentration, and (C) pH at sites 1 and 2 on Little Cottonwood Creek, near Salt Lake City, Utah, 1999-2000 water years. 

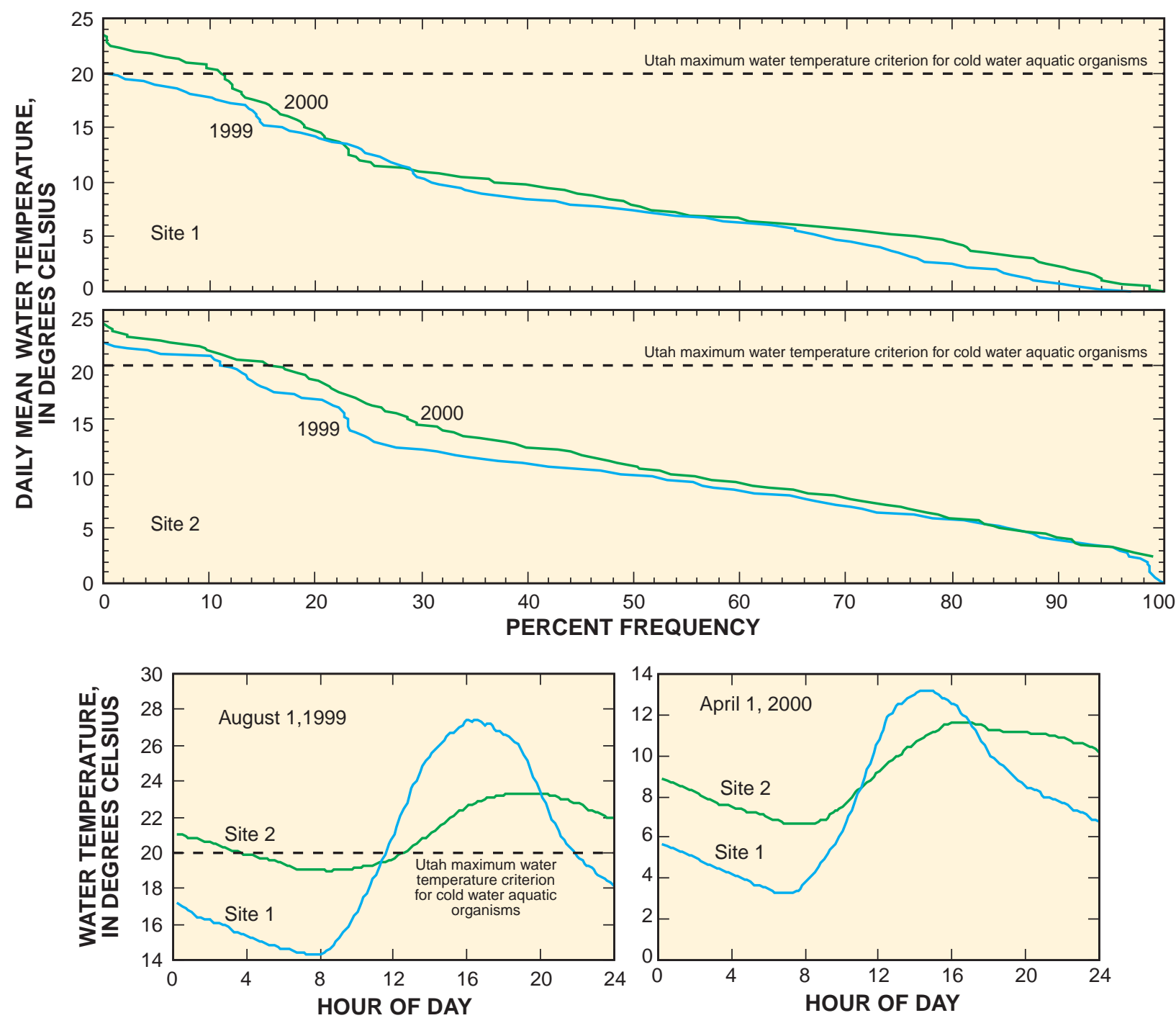

Figure 10. Cumulative frequency curves of daily mean water temperature for sites 1 and 2 on Little Cottonwood Creek, near Salt Lake City, Utah, 1999-2000 water years, and water temperature on August 1, 1999, and April 1, 2000, at sites 1 and 2.

Synoptic sampling conducted on August 31 and September 2, 1999, identified some of the changes in major-ion chemistry in the reach between sites 1 and 2 . At the time of this synoptic sampling, three substantial sources of water to the reach between sites 1 and 2 were identified. Water originating in Little Cottonwood Canyon was the dominant influence on the water chemistry from site 1 downstream to the East Jordan Canal (fig. 1). The dominant ions at sites 1 and S6 in this upper reach were calcium and bicarbonate (fig. 12). Water imported from the Jordan River and entering Little Cottonwood Creek from the East Jordan Canal through the Tower diversion was the dominant influence on water chemistry from the Tower diversion downstream to near State Street. The influence of ground-water inflow from near State Street downstream to site 2 was substantial enough to cause a change in water chemistry. The concentration of sodium, chloride, magnesium, and sulfate was higher at site 2 than it was in water imported from the Jordan River that was sampled at site S8. The dominant ions at sites S8 and 2 in this lower reach were mixed. Sodium and calcium were the dominant cations and chloride, bicarbonate, and sulfate were the dominant anions. During this synoptic study, samples were collected from most of the observed inflows in the study reach. 

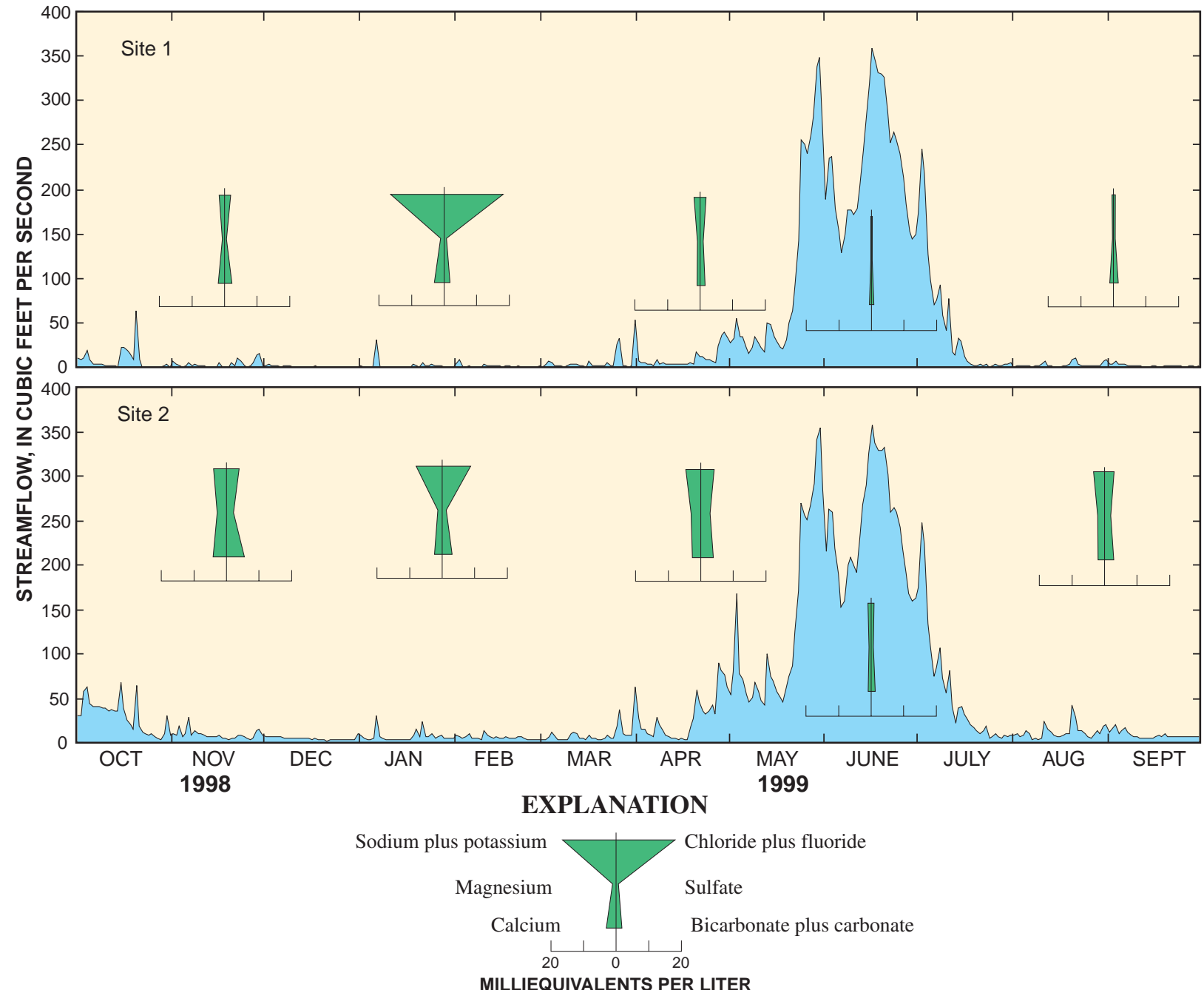

Figure 11. Chemical composition of streamflow at sites 1 and 2 on Little Cottonwood Creek, near Salt Lake City, Utah, 1999 water year.

Water collected from many of these inflows did not chemically resemble the stream water and had a greater concentration range for most solutes (Briant A. Kimball, U.S. Geological Survey, written commun., 2002).

\section{Nutrients}

Nutrients are essential to the health and function of natural ecosystems. Insufficient nutrients can result in less than optimal growth of primary producers such as aquatic vegetation and limit the diversity and productivity of the ecosystem. Excessive nutrient loading, however, can result in accelerated growth of macrophytes, oxygen declines, imbalance of predator and prey species, public health concerns, and a general decline of the aquatic ecosystem (U.S. Environmental Protection Agency, 1998b).

Nutrient transport depends on the mobility of each individual nutrient. Nitrate is readily dissolved and moves with water, whereas some forms of phosphorus attach to soil particles rather than dissolve and are transported during periods of high runoff. Nutrient sources in Little Cottonwood Creek are generally non-point. There are no permitted point discharges, such as waste-water treatment plants, which discharge into the stream. Sources of nutrients in Little Cottonwood Creek include fertilizer, plant decay, animal waste, and atmospheric deposition. 


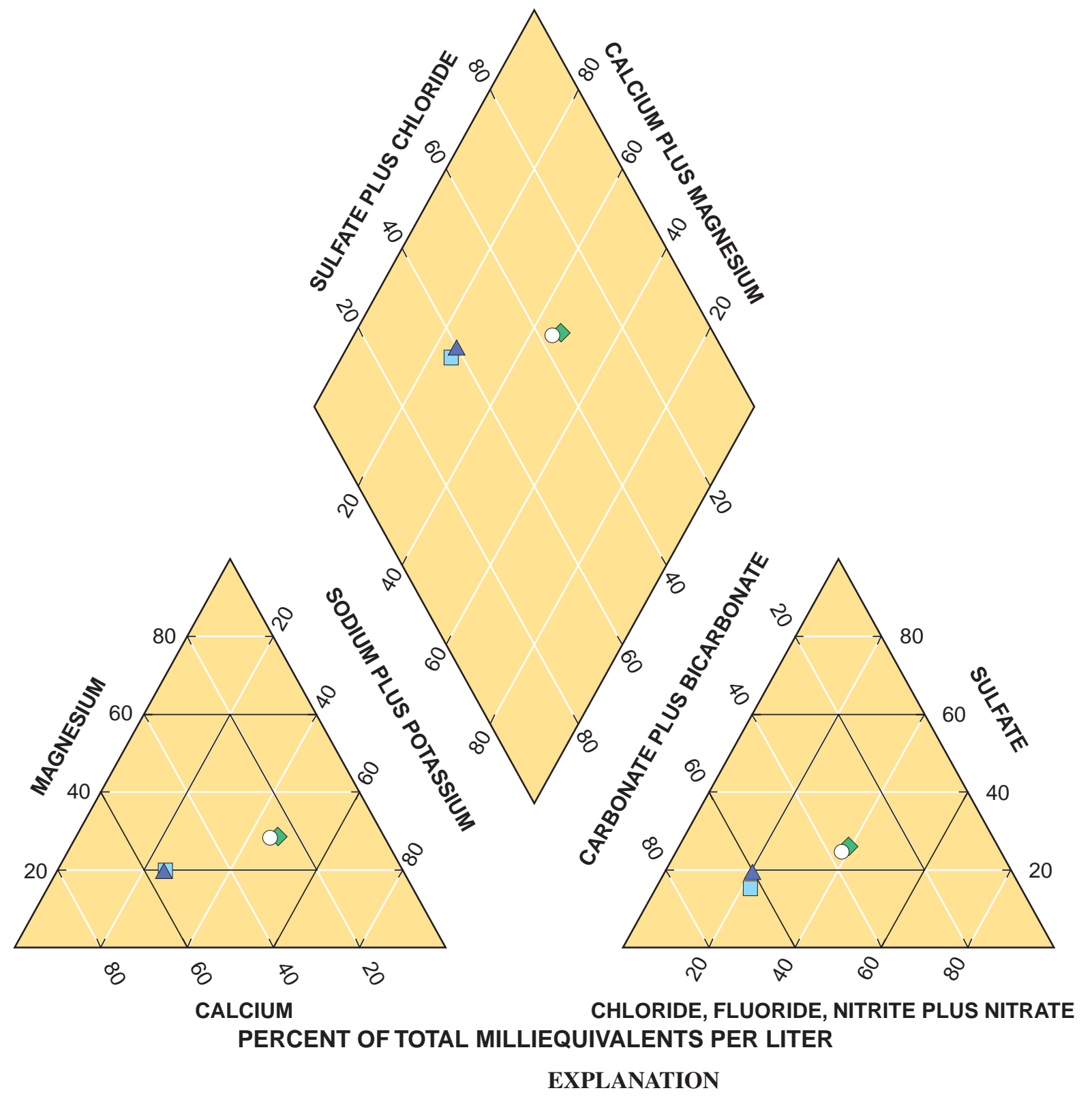

Site 1-September 2, 1999. Dissolved-solids concentration, 140 milligrams per liter Site S6-September 2, 1999. Dissolved-solids concentration, 212 milligrams per liter Site S8-August 31, 1999. Dissolved-solids concentration, 444 milligrams per liter Site 2-August 31, 1999. Dissolved-solids concentration, 472 milligrams per liter

Figure 12. Composition of water samples collected from sites 1, S6, S8, and 2 on Little Cottonwood Creek, near Salt Lake City, Utah. 
Dissolved nitrite plus nitrate (as nitrogen) concentration ranged from 0.166 to $2.62 \mathrm{mg} / \mathrm{L}$ at site 1 and from 0.241 to $1.83 \mathrm{mg} / \mathrm{L}$ at site 2 (table 2). The concentration of dissolved nitrite plus nitrate decreased at both sites with increased discharge (fig. 13) and was lowest during snowmelt runoff. The median concentration of nitrite plus nitrate at site $1(0.593$ $\mathrm{mg} / \mathrm{L})$ and site $2(0.508 \mathrm{mg} / \mathrm{L})$ was near the estimated baseline concentration of $0.6 \mathrm{mg} / \mathrm{L}$ nitrate for undeveloped areas reported by Mueller and others (1995). This is an indication that nitrite plus nitrate concentrations in the urbanized reach of Little Cottonwood Creek are generally low. National aquaticlife criteria have not been established for nitrite plus nitrate or total nitrogen in streams. The Utah Department of Environmental Quality uses concentration exceedances of $4.0 \mathrm{mg} / \mathrm{L}$ as an indicant of nitrate pollution. All nitrite plus nitrate concentrations at sites 1 and 2 were less than this pollution indicant level.

Phosphorus is entering Little Cottonwood Creek between sites 1 and 2 attached to sediment particles in surface runoff. Total phosphorus concentration at sites 1 and 2 generally increased with increased concentration of suspended sediment (fig. 14).
Phosphorus, in the suspended phase, was generally the largest component of total phosphorus at sites 1 and 2 (fig. 15). Total phosphorus concentration is greatest during spring and summer, particularly during storms or other runoff events when sediment is washed into the stream and higher streamflow velocities maintain more sediment in suspension.

During the 1999-2000 water years, the concentration of total phosphorus at site 1 ranged from 0.004 (estimated) $\mathrm{mg} / \mathrm{L}$ to $0.827 \mathrm{mg} / \mathrm{L}$ (table 2). The U.S. Environmental Protection Agency recommends a limit of $0.10 \mathrm{mg} / \mathrm{L}$ total phosphorus to control excessive growth of algae and other nuisance plants in streams (U.S. Environmental Protection Agency, 1986). The State of Utah uses $0.05 \mathrm{mg} / \mathrm{L}$ phosphate as a pollution indicator in all streams protected for the benefit of cold- and warm-water game fish and the aquatic organisms necessary for their food chain. At site 1 the concentration of total phosphorus exceeded $0.10 \mathrm{mg} / \mathrm{L}$ in 5 of 29 samples (fig. 13). At site 2, total phosphorus concentration ranged from 0.029 to 2.39 $\mathrm{mg} / \mathrm{L}$ (table 2) and exceeded $0.10 \mathrm{mg} / \mathrm{L}$ in 15 of the 45 samples.

Table 2. Summary of nutrient concentration in water samples collected from sites 1 and 2 on Little Cottonwood Creek, near Salt Lake City, Utah

[Concentration reported in milligrams per liter; <, less than; e, estimated value]

\begin{tabular}{|c|c|c|c|c|c|c|}
\hline \multirow{2}{*}{ Nutrient } & \multirow{2}{*}{$\begin{array}{c}\text { Number of } \\
\text { samples }\end{array}$} & \multicolumn{5}{|c|}{ Concentration } \\
\hline & & Minimum & 25th percentile & Median & 75th percentile & Maximum \\
\hline \multicolumn{7}{|c|}{ Site 1 (Little Cottonwood Creek at Crestwood Park) } \\
\hline Nitrogen, ammonia, dissolved & 29 & $<0.02$ & $<0.02$ & $<0.02$ & 0.026 & 0.327 \\
\hline Nitrogen, nitrite, dissolved & 29 & $<.01$ & $<.01$ & $<.01$ & $<.01$ & .028 \\
\hline Nitrogen, nitrite plus nitrate, dissolved & 29 & .166 & .270 & .593 & 1.670 & 2.62 \\
\hline Nitrogen, organic, plus ammonia, dissolved & 29 & $.07 \mathrm{e}$ & $.1 \mathrm{e}$ & .140 & .210 & .920 \\
\hline Nitrogen, organic, plus ammonia, total & 28 & .100 & .145 & .160 & .265 & 4.10 \\
\hline Phosphorus orthophosphate, dissolved & 29 & $<.01$ & $<.01$ & $<.01$ & .012 & .048 \\
\hline Phosphorus, dissolved & 29 & $.003 \mathrm{e}$ & $<.004$ & .006 & .040 & .070 \\
\hline Phosphorus, total & 29 & $.004 \mathrm{e}$ & .007 & .008 & .018 & .827 \\
\hline \multicolumn{7}{|c|}{ Site 2 (Little Cottonwood Creek at Jordan River) } \\
\hline Nitrogen, ammonia, dissolved & 45 & $<0.02$ & $<0.02$ & 0.033 & 0.104 & 0.491 \\
\hline Nitrogen, nitrite, dissolved & 45 & $<.01$ & $<.01$ & .015 & .023 & .084 \\
\hline Nitrogen, nitrite plus nitrate, dissolved & 45 & .241 & .392 & .508 & .821 & 1.83 \\
\hline Nitrogen, organic, plus ammonia, dissolved & 45 & $.1 \mathrm{e}$ & .210 & .310 & .470 & 1.50 \\
\hline Nitrogen, organic, plus ammonia, total & 44 & .200 & .320 & .535 & 1.15 & 11.0 \\
\hline Phosphorus, orthophosphate, dissolved & 45 & $<.01$ & .016 & .023 & .033 & .108 \\
\hline Phosphorus, dissolved & 45 & .005 & .012 & .021 & .043 & .156 \\
\hline Phosphorus, total & 45 & .029 & .050 & .081 & .125 & 2.39 \\
\hline
\end{tabular}



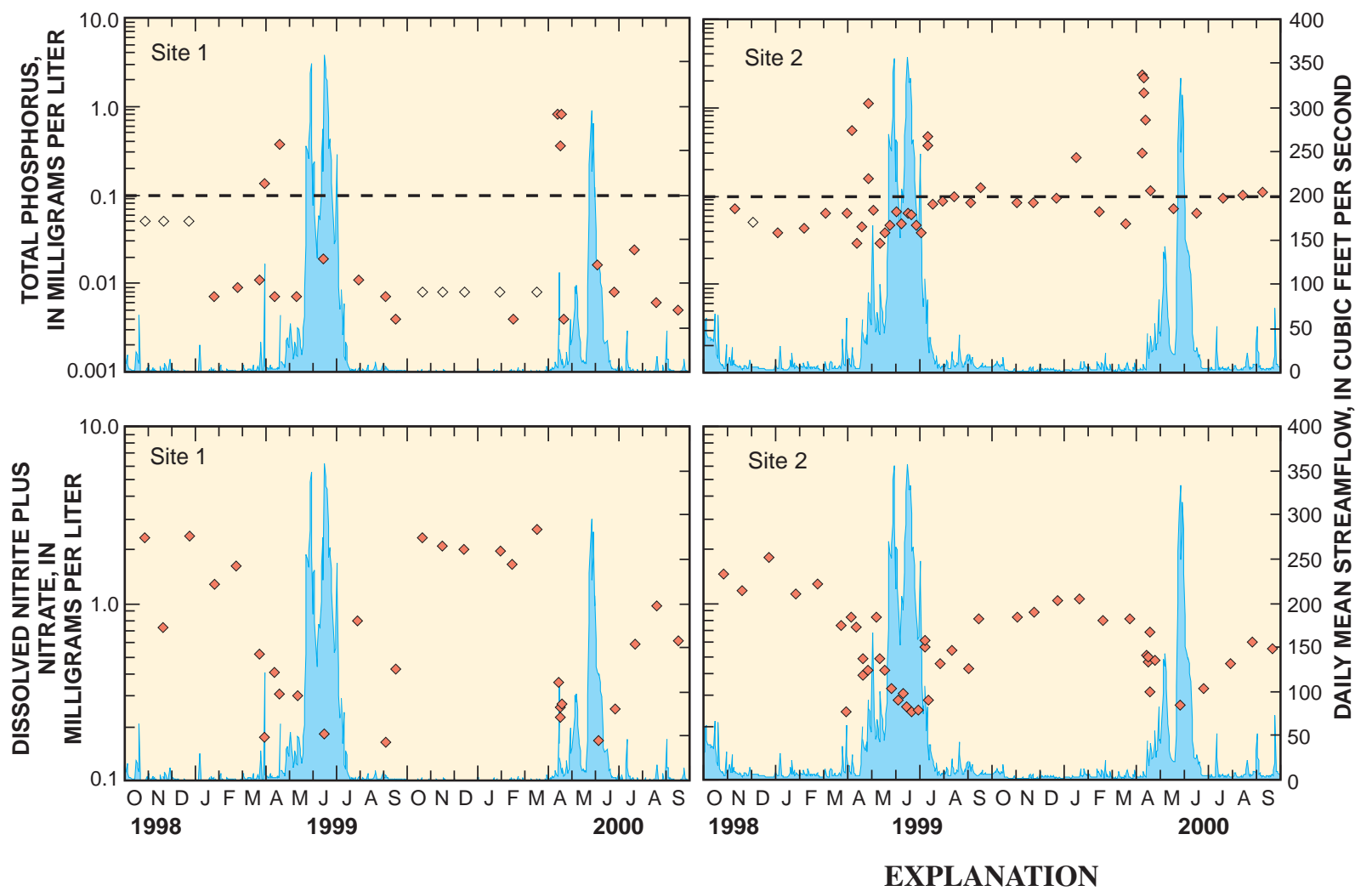

Streamflow

- - - - U.S. Environmental Protection Agency recommended maximum concentration to control aquatic plants in streams

$\diamond \quad$ Sample

$\diamond \quad$ Sample-Nondetection

Figure 13. Relation of concentration of total phosphorus and dissolved nitrite plus nitrate to streamflow at sites 1 and 2, Little Cottonwood Creek, near Salt Lake City, Utah.

\section{Trace Elements}

Samples from site 1 and 2 on Little Cottonwood Creek were analyzed for 22 trace elements (table 1). The most likely sources of trace elements in the canyon include drainage from tunnels in previously mined ore bodies, unmined ore bodies, and mine tailings. The most likely sources in the valley include mill tailings, historic smelter sites, fluvial tailings, and slag lining the creek channel for bank stabilization.

Quartile concentration values are those values that represent the 25th and 75th percentiles of a frequency distribution. Maximum and quartile concentrations of copper, zinc, and uranium were higher at site 1 than at site 2, indicating a source of these solutes in the canyon. Maximum and quartile concentrations of arsenic, boron, chromium, lithium, molybdenum, nickel, selenium, strontium, and vanadium were higher at site 2 , indicating a source in the valley and urbanized reach of Little Cottonwood Creek (table 3).

Flood plains downstream from mining districts can contain abundant deposits of fluvial tailings, particularly in areas adjacent to or downstream from older mining districts, such as the Little Cottonwood Mining District, which pre-date environmental regulations requiring containment of mine-waste materials. Resuspension and dissolution of fluvial tailings is a potential non-point source of metals in the Little Cottonwood Creek study reach. 


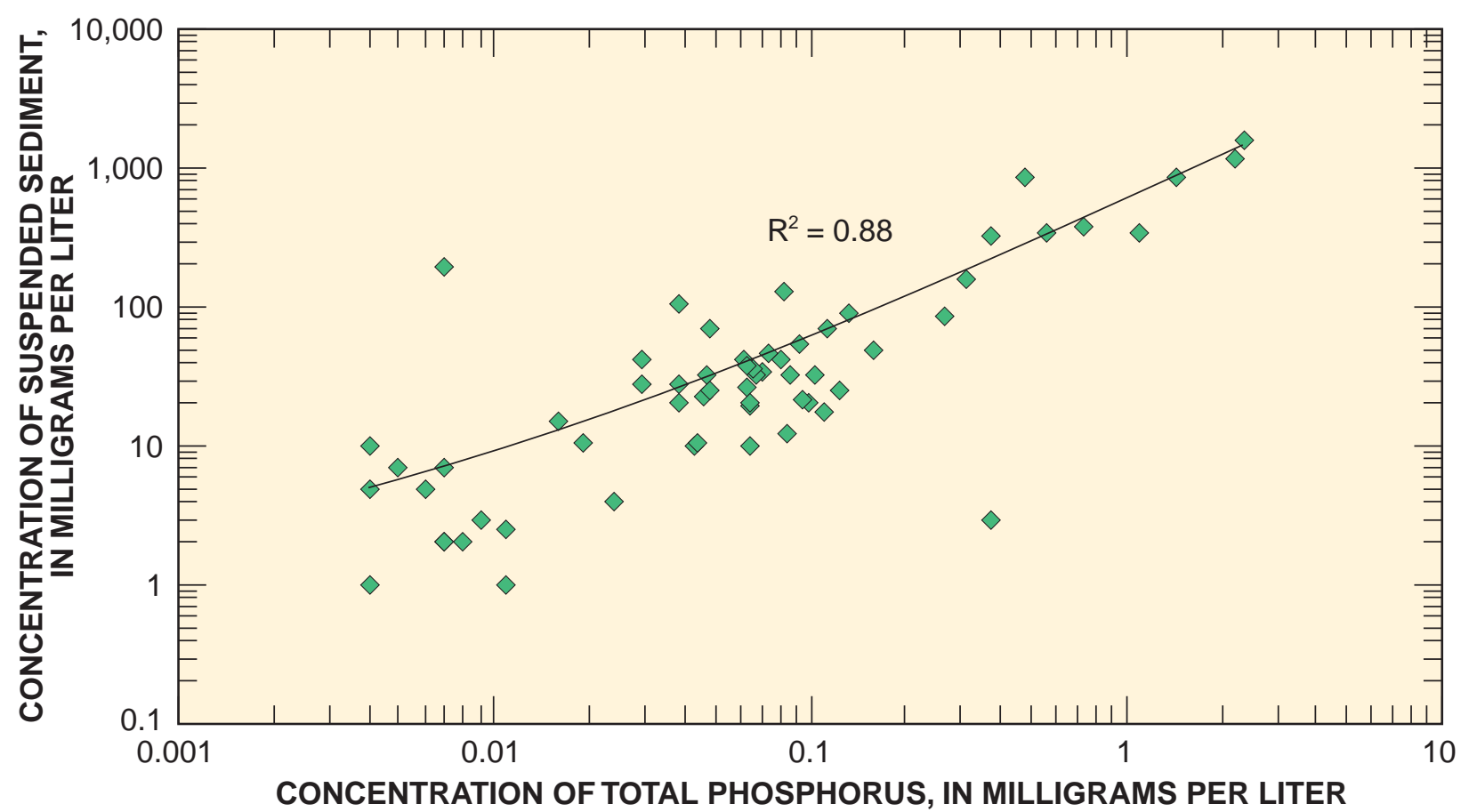

Figure 14. Relation of concentration of suspended sediment to total phosphorus in samples from sites 1 and 2, Little Cottonwood Creek, near Salt Lake City, Utah.

A summary of trace-element concentrations for sites 1 and 2 during the 1999-2000 water years, drinking-water standards, and aquatic-life criteria are presented in table 3. Drinking-water standards are provided for comparison even though none of the water in the study reach is used for drinking water. Aquaticlife criteria for cadmium, copper, lead, nickel, and zinc are hardness dependent. As the hardness of stream water increases, the aquatic-life criterion concentration of these trace metals increases. In table 3, values of hardness-dependent trace metal aquatic-life criteria are based on a hardness of $100 \mathrm{mg} / \mathrm{L}$ calcium carbonate. The average hardness at the fixed sites was $143 \mathrm{mg} / \mathrm{L}$ as calcium carbonate at site 1 and $226 \mathrm{mg} / \mathrm{L}$ at site 2 .

Arsenic was detected in 16 of 25 samples at site 1 in concentrations ranging from 0.7 to $7.5 \mu \mathrm{g} / \mathrm{L}$ (table 3). Arsenic was detected in all 49 samples collected at site 2 with concentrations ranging from 4.7 to 284 $\mu \mathrm{g} / \mathrm{L}$. Synoptic sampling during August 1999 in the urban reach between sites 1 and 2 on Little Cottonwood Creek indicated surface runoff and sub- surface drainage in the vicinity of site $\mathrm{S} 20$ (fig. 2) near the Murray smelter tailings as the likely source of arsenic solutes. Arsenic concentrations were less than the U.S. Environmental Protection Agency (USEPA) aquatic-life criterion of $150 \mu \mathrm{g} / \mathrm{L}$ and the Utah aquaticlife criterion of $190 \mathrm{mg} / \mathrm{L}$ at site 1 ; at site 2 the USEPA criterion was exceeded in 8 of 49 samples (fig. 16) and the Utah criterion was exceeded in 4 of 49 samples.

Copper concentration at sites 1 and 2 was elevated during snowmelt runoff relative to base flow during water year 1999, with a maximum concentration of $5.7 \mu \mathrm{g} / \mathrm{L}$ occurring at site 2 during May (fig. 16). Copper concentration measured during snowmelt runoff in water year 2000 was lower, probably because of decreased runoff from Little Cottonwood Canyon. A synoptic study in September 1998 (Gerner and others, 2001) determined that copper concentration ranged from less than 1 to $144 \mu \mathrm{g} / \mathrm{L}$ at 91 sites in Little Cottonwood Canyon. During snowmelt, some copper is probably transported into the valley in the reach that includes sites 1 and 2. 


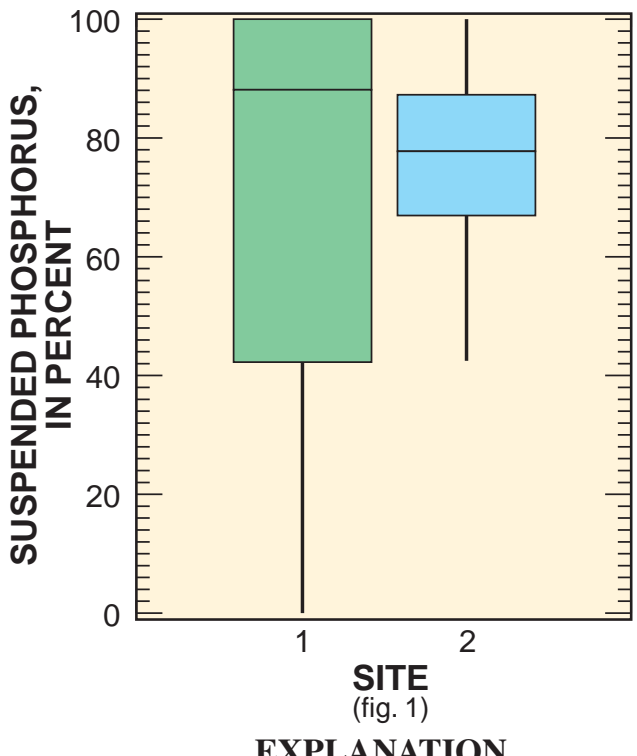

EXPLANATION

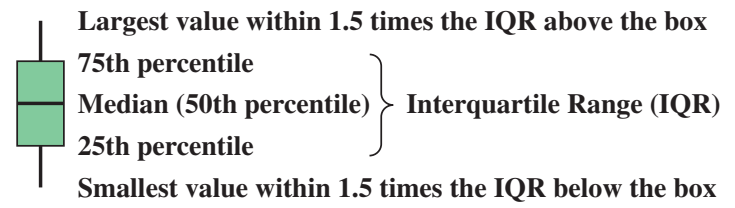

Figure 15. Percentage of phosphorus in the suspended phase in samples from sites 1 and 2, Little Cottonwood Creek, near Salt Lake City, Utah.

Synoptic sampling conducted on August 31 and September 2, 1999, showed the distribution and possible sources of arsenic, copper, and zinc. Samples were collected at a subset of 23 synoptic sites including fixed sites 1 and 2 and were analyzed for trace elements (fig. 2). The water originating from the East Jordan Canal and other sources downstream from the Tower diversion appears to contribute additional constituents to Little Cottonwood Creek that are not present above the Tower diversion. No arsenic was detected between sites 1 and S7 (fig. 17). Most of the water in the stream was being withdrawn between sites S7 and S8. Water from the Salt Lake and East Jordan Canal (at the Tower diversion, fig. 1) entered the stream immediately upstream of site S8. The sample from site S8 indicated that some arsenic was present in water from this canal. Arsenic concentration measured in samples from sites S8 downstream to site $\mathrm{S} 19$ ranged from 4.7 to $8.4 \mu \mathrm{g} / \mathrm{L}$. Arsenic concentration measured at sites S20, S21, and 2 was considerably higher and ranged from $42 \mu \mathrm{g} / \mathrm{L}$ to
$46 \mu \mathrm{g} / \mathrm{L}$. Sites S20 and S21 were downstream from State Street in the vicinity of the Murray smelter site (fig. 1).

Zinc concentration was highest in samples from site 1 downstream to site $\mathrm{S} 7$ and ranged from 7 to 16 $\mu \mathrm{g} / \mathrm{L}$. Zinc concentration was lower in samples collected below the Tower diversion, with concentration ranging from 3 to $7 \mu \mathrm{g} / \mathrm{L}$. Copper concentration in synoptic samples ranged from 2 to 3 $\mu \mathrm{g} / \mathrm{L}$ at all sites.

\section{Pesticides}

Pesticides applied in the urban environment have a higher probability of being transported to surfacewater bodies than pesticides applied in a nonurban environment because of extensive impermeable surfaces present in urban areas (Larson and others, 1997). Pesticides can reach the impermeable surfaces from direct application, spray drift, atmospheric deposition, or runoff from lawns and gardens. Application of pesticides to yards, gardens, golf courses, and public space in the urban areas of the Little Cottonwood Creek drainage basin is greatest during March through September.

Samples collected for pesticide analysis targeted those periods and events most likely to result in pesticide detection. Detection frequencies are likely biased because periods with minimal pesticide application were sampled at a lower intensity than periods when pesticides were often applied. The pesticide compounds analyzed for in samples collected from Little Cottonwood Creek are shown in table 4. Eighteen pesticides were detected at site 1, and 32 were detected at site 2 . The detected pesticides include 23 herbicides, 4 herbicide metabolites, 5 insecticides, and 1 fungicide.

Eighteen pesticides were detected in water samples from sites 1 and 2 by using gas chromatography/mass spectrometry (GC/MS) analysis (table 5). The following pesticides were detected in water samples from sites 1 and 2 by using highperformance liquid chromatography/mass spectrometry (HPLC/MS) analysis:

Site 1 (Little Cottonwood Creek at Crestwood Park) $2,4 \mathrm{D}$

Clopyralid

Dicamba 
Table 3. Summary of trace-element concentration in water samples collected from sites 1 and 2 on Little Cottonwood Creek, near Salt Lake City, Utah

[Concentration reported in micrograms per liter; v, analyte was detected in both environmental and blank samples; <, less than; —, not established; e, estimated value; concentration in bold italics exceeds aquatic-life criterion]

\begin{tabular}{|c|c|c|c|c|c|c|c|c|}
\hline \multirow{2}{*}{ Constituent } & \multirow{2}{*}{$\begin{array}{l}\text { Number of } \\
\text { samples }\end{array}$} & \multirow{2}{*}{$\begin{array}{l}\text { Percent } \\
\text { detects }\end{array}$} & \multicolumn{3}{|c|}{ Concentration } & \multirow{2}{*}{$\begin{array}{l}\text { Drinking water } \\
\text { standard }^{1}\end{array}$} & \multirow{2}{*}{$\begin{array}{c}\text { Aquatic- } \\
\text { life criterion }\end{array}$} & \multirow{2}{*}{$\begin{array}{l}\text { Utah aquatic-life } \\
\text { criterion }^{3}\end{array}$} \\
\hline & & & Maximum & 75th percentile & 25th percentile & & & \\
\hline \multicolumn{9}{|c|}{$\begin{array}{c}\text { Site 1 } \\
\text { (Little Cottonwood Creek at Crestwood Park) }\end{array}$} \\
\hline Aluminum & 25 & 96 & $33.1 \mathrm{v}$ & $<14.9$ & $4.8 \mathrm{v}$ & $50-{ }^{4} 200$ & - & 587 \\
\hline Antimony & 25 & 56 & 1.9 & 1.6 & $<1$ & 6 & 30 & - \\
\hline Arsenic & 25 & 64 & 7.5 & $1.6 \mathrm{e}$ & $<1$ & 10 & 150 & 5,6190 \\
\hline Barium & 25 & 100 & 241 & 126 & 42.0 & 2,000 & - & - \\
\hline Beryllium & 25 & 0 & $<1$ & $<1$ & $<1$ & 4 & 5.3 & - \\
\hline Boron & 7 & 100 & 23.7 & 19.2 & 9.5 & - & - & - \\
\hline Cadmium & 25 & 0 & $<1$ & $<1$ & $<1$ & 5 & ${ }^{7} 2.2$ & $5,71.1$ \\
\hline Chromium & 25 & 20 & 1.3 & $<1$ & $<.8$ & 100 & 811 & - \\
\hline Cobalt & 25 & 0 & $<1$ & $<1$ & $<1$ & - & - & - \\
\hline Copper & 25 & 100 & 5.3 & 4.0 & 2.8 & ${ }^{9} 1,300$ & ${ }^{7} 9.0$ & 5,712 \\
\hline Lead & 25 & 0 & $<1$ & $<1$ & $<1$ & ${ }^{9} 15$ & ${ }^{7} 2.5$ & $5,73.2$ \\
\hline Lithium & 7 & 100 & 4.7 & 3.6 & 1.5 & - & - & - \\
\hline Molybdenum & 25 & 100 & 9.0 & 5.9 & 3.1 & ${ }^{10} 40$ & - & - \\
\hline Nickel & 25 & 44 & 1.9 & 1.2 & $<1$ & ${ }^{10} 100$ & ${ }^{7} 52$ & ${ }^{5,7} 160$ \\
\hline Selenium & 25 & 32 & 2.4 & 1.4 & $<1$ & 50 & 5 & $5_{5}$ \\
\hline Silver & 25 & 0 & $<1$ & $<1$ & $<1$ & ${ }^{10} 100$ & - & ${ }^{5} 10$ \\
\hline Strontium & 7 & 100 & 468 & 214 & 140 & ${ }^{10} 4,000$ & - & - \\
\hline Thallium & 7 & 0 & $<.9$ & $<.9$ & $<.9$ & 2 & 40 & - \\
\hline Vanadium & 7 & 0 & $<1$ & $<1$ & $<1$ & - & - & - \\
\hline Zinc & 25 & 96 & $58.3 \mathrm{v}$ & $27.0 \mathrm{v}$ & $13.7 \mathrm{v}$ & ${ }^{10} 2,000$ & ${ }^{7} 120$ & ${ }^{5,7} 110$ \\
\hline Uranium, natural & 25 & 88 & 72.8 & 24.8 & 1.6 & 30 & - & - \\
\hline
\end{tabular}

(Little Cottonwood Creek at Jordan River)

\begin{tabular}{|c|c|c|c|c|c|c|c|c|}
\hline Aluminum & 45 & 87 & $23.0 \mathrm{v}$ & $11.8 \mathrm{v}$ & $3.1 \mathrm{v}$ & $50-{ }^{4} 200$ & - & 587 \\
\hline Antimony & 45 & 53 & 5.1 & 1.4 & $<1$ & 6 & 30 & - \\
\hline Arsenic & 49 & 100 & 284 & 87.3 & 11.7 & 10 & 150 & 5,6190 \\
\hline Barium & 45 & 100 & 161 & 112 & 44.0 & 2,000 & - & - \\
\hline Beryllium & 45 & 0 & $<2$ & $<1$ & $<1$ & 4 & 5.3 & - \\
\hline Boron & 8 & 100 & 264 & 240 & 130 & - & - & - \\
\hline Cadmium & 45 & 0 & $<2$ & $<1$ & $<1$ & 5 & ${ }^{7} 2.2$ & $5,71.1$ \\
\hline Chromium & 45 & 24 & 3.0 & $<1$ & $<.8$ & 100 & ${ }^{8} 11$ & - \\
\hline Cobalt & 45 & 0 & $<2$ & $<1$ & $<1$ & - & - & - \\
\hline Copper & 45 & 100 & 5.7 & 3.0 & 2.0 & ${ }^{9} 1,300$ & ${ }^{7} 9.0$ & 5,712 \\
\hline Lead & 45 & 12 & 1.3 & $<1$ & $<1$ & ${ }^{9} 15$ & ${ }^{7} 2.5$ & $5,73.2$ \\
\hline Lithium & 8 & 100 & 109 & 98.5 & 36.6 & - & - & - \\
\hline Molybdenum & 45 & 100 & 13.5 & 8.5 & 3.9 & 1040 & - & - \\
\hline Nickel & 45 & 76 & 3.7 & 2.0 & 1.1 & ${ }^{10} 100$ & ${ }^{7} 52$ & 5,7160 \\
\hline Selenium & 45 & 62 & 6.0 & 2.3 & $<1$ & 50 & 5 & 55 \\
\hline Silver & 45 & 0 & $<2$ & $<1$ & $<1$ & ${ }^{10} 100$ & - & ${ }^{5} 10$ \\
\hline Strontium & 8 & 100 & 934 & 826 & 502 & ${ }^{10} 4,000$ & - & - \\
\hline Thallium & 8 & 0 & $<.9$ & $<.9$ & $<.9$ & 2 & 40 & - \\
\hline Vanadium & 8 & 75 & 3.5 & 2.9 & $<1$ & - & - & - \\
\hline Zinc & 45 & 87 & $40.2 \mathrm{v}$ & $20.9 \mathrm{v}$ & $9.8 \mathrm{v}$ & $10_{2,000}$ & ${ }^{7} 120$ & 5,7110 \\
\hline Uranium, natural & 45 & 100 & 21.6 & 10.2 & 3.3 & 30 & - & - \\
\hline $\begin{array}{r}{ }^{1} \text { U.S. Envirc } \\
{ }^{2} \text { Criteria Co } \\
\text { Environmental Pro } \\
{ }^{3} \text { Utah Depa } \\
{ }^{4} \text { Secondary } \\
{ }^{5} \text { Values are }\end{array}$ & $\begin{array}{l}\text { Prote } \\
\text { Conc } \\
\text { genc } \\
\text { Envir } \\
\text { vater }\end{array}$ & $\begin{array}{l}\text { (syncy, } \\
\text { l Qua } \\
\text { on. } \\
\text { for b }\end{array}$ & $\begin{array}{l}2 . \\
\text { nous with } \\
1997 . \\
\text { icial use }\end{array}$ & ic'), U.S. & $\begin{array}{l}{ }^{6} \text { Arse } \\
{ }^{7} \text { Harc } \\
{ }^{8} \mathrm{Chrc} \\
{ }^{9} \mathrm{Acti} \\
{ }^{10} \mathrm{Lif}\end{array}$ & $\begin{array}{l}\text { value bas } \\
\text { ng treatm } \\
\text { lvisory. }\end{array}$ & $100 \mathrm{mg}$ & $\mathrm{CO}_{3}$ \\
\hline
\end{tabular}




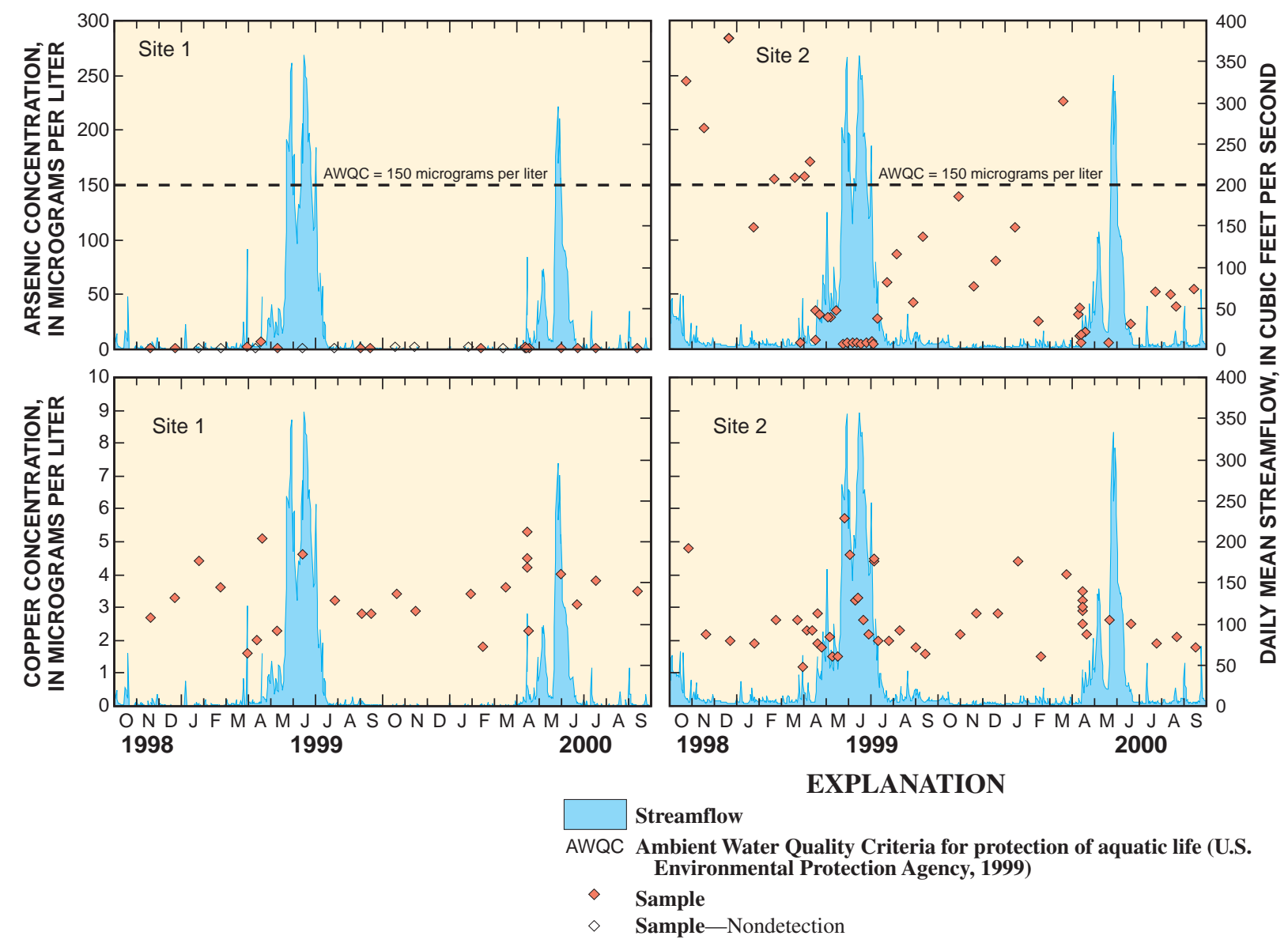

Figure 16. Relation of concentration of arsenic and copper to streamflow at sites 1 and 2 on Little Cottonwood Creek, near Salt Lake City, Utah.

Diuron

MCPA

Site 2 (Little Cottonwood Creek at Jordan River)

$2,4 \mathrm{D}$

$2,4 \mathrm{DB}$

2,4 D Methyl ester

2-Hydroxyatrazine

Benomyl

Bromacil

Deethyldeisopropylatrazine

Deisopropylatrazine

Dicamba

Diuron

Flumetsulam

Imazaquin

MCPA

Triclopyr
Prometon is a broad-spectrum herbicide used on non-crop areas including rights-of-way. At the common reporting limit of $0.01 \mu \mathrm{g} / \mathrm{L}$, prometon was the most frequently detected pesticide at both sites. It was detected in 78 percent of the samples for which it was analyzed from site 1 and 79 percent of the samples for which it was analyzed from site 2 (table 5). Prometon concentration was the highest measured among all detected pesticides, as high as $0.978 \mu \mathrm{g} / \mathrm{L}$ at site 1 and $5.61 \mu \mathrm{g} / \mathrm{L}$ at site 2 . There is no established aquatic-life criterion for prometon; however, a median $\mathrm{LC}^{50}$ value, the concentration at which 50-percent mortality occurs, of $19,600 \mu \mathrm{g} / \mathrm{L}$ for freshwater fish was reported in Munn and Gilliom (2001) in a summary table of data from the USEPA Pesticide Ecotoxicity Database. An EC ${ }^{50}$ value, the concentration at which 50 percent of test organisms exhibit nonlethal responses, of $25,800 \mu \mathrm{g} / \mathrm{L}$ for water 


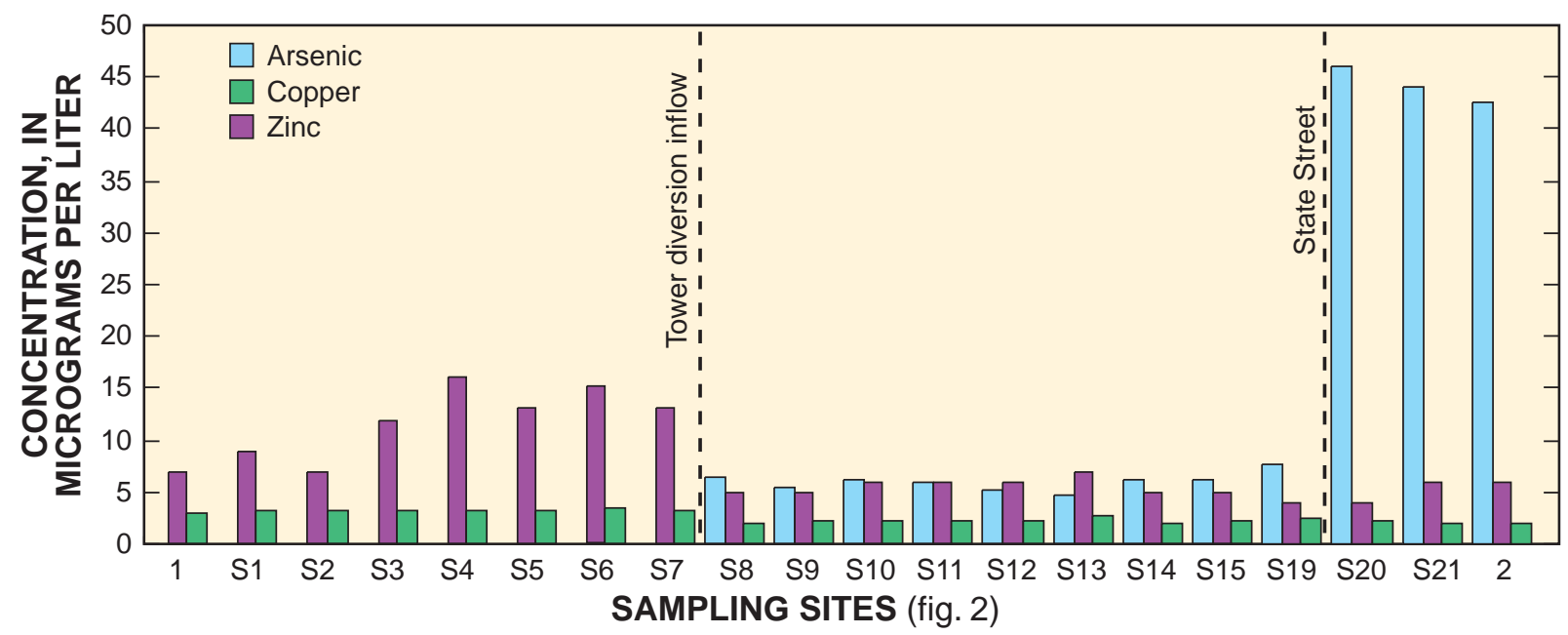

Figure 17. Concentration of arsenic, copper, and zinc in water collected from Little Cottonwood Creek, near Salt Lake City, Utah, August 31 and September 2, 1999.

fleas and $98 \mu \mathrm{g} / \mathrm{L}$ for green algae was reported in a summary table in Capel and others (1999). On the basis of comparisons of the concentration of prometon in Little Cottonwood Creek to the few $\mathrm{LC}^{50}$ and $\mathrm{EC}^{50}$ values determined for aquatic organisms, there seems to be little threat of acute toxicity from prometon to aquatic organisms in the study reach.

The second most frequently detected pesticide at both sites was diazinon, which is an organophosphate insecticide. It is currently (2002) one of the most widely used insecticides in the United States, especially for household lawn and garden pest control. The concentration of diazinon exceeded the aquatic-life criterion of $0.08 \mu \mathrm{g} / \mathrm{L}$ (International Joint Commission United States and Canada, 1989) in 4 of 9 samples collected at site 1 and 8 of 42 samples collected at site 2 (table 5). The highest concentration of diazinon measured was $0.343 \mu \mathrm{g} / \mathrm{L}$ at site 2 .

Carbaryl was detected in more than 40 percent of the samples at the common reporting limit of 0.01 $\mu \mathrm{g} / \mathrm{L}$. The aquatic-life criterion for carbaryl had no exceedances in samples from site 1 ; in samples from site 2 the concentration of carbaryl exceeded the aquatic-life criterion of $0.2 \mu \mathrm{g} / \mathrm{L}$ (Canadian Council of Ministers of the Environment, 2001) in 4 of 42 samples. The concentration of the insecticide malathion exceeded the aquatic-life criterion of 0.1 $\mu \mathrm{g} / \mathrm{L}$ (U.S. Environmental Protection Agency, 1999) in 2 of 9 samples from site 1 and 1 of 42 samples from site 2 .

At site 2, where more frequent sampling occurred than at site 1 , seasonal patterns in pesticide concentration were noted for several pesticides. Prometon, atrazine, diazinon, and carbaryl concentrations were highest during low or base-flow periods, which occur during late fall to early spring (fig. 18). Prometon and diazinon had secondary peaks during late summer. Application of prometon and diazinon begins in spring; however, samples collected during spring runoff had lower concentrations as a result of dilution from snowmelt in the upper canyon. Secondary peaks in concentration of these pesticides may be the result of additional summer application on lawns, orchards, and gardens in the case of diazinon, and rights-of-way in the case of prometon. The highest concentrations of prometon, diazinon, and carbaryl occurred during spring or summer storms. The highest concentration of atrazine occurred during late fall to early winter when most of the flow in Little Cottonwood Creek is from ground-water inflow and surface runoff from residential and commercial land uses. 
Table 4. Minimum reporting level of pesticides analyzed for in water samples collected at fixed sites on Little Cottonwood Creek, near Salt Lake City, Utah

[MRL, minimum reporting level; $\mu \mathrm{g} / \mathrm{L}$, micrograms per liter; GC/MS, gas chromatography/mass spectrometry; HPLC/MS, high-performance liquid chromatography/mass spectrometry; H, herbicide; HM, herbicide metabolite; I, insecticide; IM, insecticide metabolite; F, fungicide]

\begin{tabular}{|c|c|c|}
\hline Pesticide & Type & $\begin{array}{c}\text { MRL } \\
(\mu \mathrm{g} / \mathrm{L})\end{array}$ \\
\hline \multicolumn{3}{|c|}{ Pesticides analyzed by GC/MS ${ }^{1}$} \\
\hline Acetochlor & $\mathrm{H}$ & 0.002 \\
\hline Alachlor & $\mathrm{H}$ & .002 \\
\hline Aniline, 2,6-diethyl & HM & .003 \\
\hline Atrazine & $\mathrm{H}$ & .001 \\
\hline Atrazine, Desethyl & HM & .002 \\
\hline Azinphos-methyl & I & .001 \\
\hline Benefin & $\mathrm{H}$ & .002 \\
\hline Butylate & $\mathrm{H}$ & .002 \\
\hline Carbaryl & I & .003 \\
\hline Carbofuran & I & .003 \\
\hline Chlorpyrifos & I & .004 \\
\hline Cyanazine & $\mathrm{H}$ & .004 \\
\hline Dacthal & $\mathrm{H}$ & .002 \\
\hline Deethylatrazine & $\mathrm{H}$ & .006 \\
\hline$p, p^{\prime}-\mathrm{DDE}$ & $\mathrm{IM}$ & .006 \\
\hline Diazinon & I & .002 \\
\hline Dieldrin & I & .001 \\
\hline Disulfoton & I & .017 \\
\hline EPTC & $\mathrm{H}$ & .002 \\
\hline Ethalfluralin & $\mathrm{H}$ & .004 \\
\hline Ethoprop & I & .003 \\
\hline Ethyl Parathion & I & .004 \\
\hline Fonofos & I & .003 \\
\hline $\mathrm{HCH}$, -alpha & $\mathrm{IM}$ & .002 \\
\hline Lindane (Gamma-hch) & I & .004 \\
\hline Linuron & $\mathrm{H}$ & .002 \\
\hline Malathion & I & .005 \\
\hline Methyl Parathion & I & .006 \\
\hline Metolachlor & $\mathrm{H}$ & .002 \\
\hline Metribuzin & $\mathrm{H}$ & .004 \\
\hline Molinate & $\mathrm{H}$ & .004 \\
\hline Napropamide & $\mathrm{H}$ & .003 \\
\hline Pebulate & $\mathrm{H}$ & .004 \\
\hline Pendimethalin & $\mathrm{H}$ & .004 \\
\hline Permethrin & I & .005 \\
\hline Phorate & I & .002 \\
\hline Prometon & $\mathrm{H}$ & .018 \\
\hline Pronamide (Propyzamide) & $\mathrm{H}$ & .003 \\
\hline Propachlor & $\mathrm{H}$ & .007 \\
\hline Propanil & $\mathrm{H}$ & .004 \\
\hline Propargite & I & .013 \\
\hline Simazine & $\mathrm{H}$ & .005 \\
\hline Tebuthiuron & $\mathrm{H}$ & .01 \\
\hline Terbacil & $\mathrm{H}$ & .007 \\
\hline Terbufos & I & .013 \\
\hline Thiobencarb & $\mathrm{H}$ & .002 \\
\hline Triallate & $\mathrm{H}$ & .001 \\
\hline Trifluralin & $\mathrm{H}$ & .002 \\
\hline \multicolumn{3}{|c|}{ Pesticides analyzed by HPLC/MS ${ }^{2}$} \\
\hline $2,4-\mathrm{D}$ & $\mathrm{H}$ & 0.0774 \\
\hline 2,4-D methyl ester & $\mathrm{H}$ & .0865 \\
\hline $2,4-\mathrm{DB}$ & $\mathrm{H}$ & ${ }^{3} .0538$ \\
\hline 2-Hydroxyatrazine & HM & ${ }^{3} .1927$ \\
\hline 3(4-Chlorophenyl)-1-methyl urea & $\mathrm{HM}$ & .0915 \\
\hline 3-Hydroxycarbofuran & $\mathrm{IM}$ & .0623 \\
\hline 3-Ketocarbofuran & $\mathrm{IM}$ & ${ }^{3} .0723$ \\
\hline Acifluorfen & $\mathrm{H}$ & .0622 \\
\hline Aldicarb & I & ${ }^{3} .0815$ \\
\hline Aldicarb sulfone & IM & ${ }^{3} .1599$ \\
\hline Aldicarb sulfoxide & $\mathrm{IM}$ & .0271 \\
\hline Bendiocarb & I & .0612 \\
\hline
\end{tabular}

\begin{tabular}{|c|c|c|}
\hline Pesticide & Type & $\begin{array}{c}\text { MRL } \\
(\mu \mathrm{g} / \mathrm{L})\end{array}$ \\
\hline \multicolumn{3}{|c|}{ Pesticides analyzed by HPLC/MS ${ }^{2}$ - Continued } \\
\hline Benomyl & $\mathrm{F}$ & .0219 \\
\hline Bensulfuron-methyl & $\mathrm{H}$ & .0482 \\
\hline Bentazon & $\mathrm{H}$ & ${ }^{3} .0193$ \\
\hline Bromacil & $\mathrm{H}$ & ${ }^{3} .0807$ \\
\hline Bromoxynil & $\mathrm{H}$ & ${ }^{3} .0572$ \\
\hline Carbaryl & $\mathrm{H}$ & .0628 \\
\hline Carbofuran & $\mathrm{H}$ & .566 \\
\hline Chloramben methyl ester & $\mathrm{H}$ & 3.1139 \\
\hline Chlorimuron-ethyl & $\mathrm{H}$ & .0367 \\
\hline Chlorothalonil & $\mathrm{H}$ & ${ }^{3} .0485$ \\
\hline Clopyralid & $\mathrm{H}$ & .0411 \\
\hline Cycloate & $\mathrm{H}$ & ${ }^{3} .0543$ \\
\hline Dacthal monoacid & HM & .0722 \\
\hline Deethylatrazine & HM & ${ }^{3} .0868$ \\
\hline Deethyldeisopropylatrazine & HM & ${ }^{3} .0599$ \\
\hline Deisopropylatrazine & HM & ${ }^{3} .0737$ \\
\hline Dicamba & $\mathrm{H}$ & .096 \\
\hline Dichlorprop & $\mathrm{H}$ & .05 \\
\hline Dinoseb & $\mathrm{H}$ & .0429 \\
\hline Diphenamid & $\mathrm{H}$ & .0581 \\
\hline Diuron & $\mathrm{H}$ & .0793 \\
\hline Fenuron & $\mathrm{H}$ & .0735 \\
\hline Flumetsulam & $\mathrm{H}$ & ${ }^{3} .0866$ \\
\hline Fluometuron & $\mathrm{H}$ & .0617 \\
\hline Imazaquin & $\mathrm{H}$ & 3.103 \\
\hline Imazethapyr & $\mathrm{H}$ & ${ }^{3} .0879$ \\
\hline Imidacloprid & I & .106 \\
\hline Linuron & $\mathrm{H}$ & .0695 \\
\hline MCPA & $\mathrm{H}$ & .0585 \\
\hline МСРB & $\mathrm{H}$ & ${ }^{3} .0625$ \\
\hline Metalaxyl & $\mathrm{H}$ & .0571 \\
\hline Methiocarb & $\mathrm{I}$ & ${ }^{3} .0795$ \\
\hline Methomyl & I & ${ }^{3} .0768$ \\
\hline Methomyl oxime & IM & ${ }^{3} .0102$ \\
\hline Metsulfuron methyl & $\mathrm{H}$ & 3.1138 \\
\hline Neburon & $\mathrm{H}$ & .0747 \\
\hline Nicosulfuron & $\mathrm{H}$ & .0653 \\
\hline Norflurazon & $\mathrm{H}$ & ${ }^{3} .0774$ \\
\hline Oryzalin & $\mathrm{H}$ & .0711 \\
\hline Oxamyl & I & .016 \\
\hline Oxamyl oxime & IM & ${ }^{3} .0644$ \\
\hline Picloram & $\mathrm{H}$ & .0712 \\
\hline Propham & $\mathrm{H}$ & .0717 \\
\hline Propiconazole & $\mathrm{F}$ & .0643 \\
\hline Propoxur & I & .0594 \\
\hline Siduron & $\mathrm{H}$ & .0933 \\
\hline Sulfometuron-methyl & $\mathrm{H}$ & .0388 \\
\hline Terbacil & $\mathrm{H}$ & ${ }^{3} .0954$ \\
\hline Tribenuron-methyl & $\mathrm{H}$ & ${ }^{3} .0678$ \\
\hline Triclopyr & $\mathrm{H}$ & .1008 \\
\hline
\end{tabular}

${ }^{1}$ GC/MS, U.S. Geological Survey National Water-Quality

Laboratory schedule 2001, 2010.

${ }^{2}$ HPLC/MS, U.S. Geological Survey National Water-Quality Laboratory schedule LC9060.

${ }^{3}$ Concentration is always reported as "estimated" because of variability of recovery. 
Synoptic sampling conducted on August 31 and September 2, 1999, showed the distribution and possible sources of pesticides. Water samples collected from sites 1 and S6 had fewer pesticides detected than samples collected from sites S8 and 2 (fig. 19). Concentrations of diazinon and prometon were highest in samples from the two upstream sites (sites 1 and S6). Carbaryl also was detected in samples from the upstream sites but in lower concentrations than at the downstream sites. Malathion and atrazine also were detected at one or both downstream sites, S8 and 2.

\section{Volatile Organic Compounds}

Volatile organic compounds (VOCs) are a class of compounds present in large quantities and used in many ways. They are present in fuels, exhaust, paint, adhesives, solvents, refrigerants, pesticides, and fumigants. Likely pathways for VOCs to enter a watershed include: (1) direct discharge into a stream from accidental spills and industrial or wastewater discharge, and (2) industrial and vehicle emissions, scavenged from the air by precipitation, deposited directly into a stream, or transported there in runoff.

Samples collected for VOC analysis at sites 1 and 2 on Little Cottonwood Creek were analyzed for 86 compounds (table 6). Two samples were collected from site 1 and 32 samples were collected from site 2 . Benzene, chloroform, and toluene were detected in the two samples collected from site 1 . A common reporting limit of $0.05 \mu \mathrm{g} / \mathrm{L}$ was used to compare the detection frequencies of VOCs that have different MRLs. Chloroform was the only compound detected at site 1 above the $0.05 \mu \mathrm{g} / \mathrm{L}$ common reporting limit (table 7). At site 2, 28 compounds were detected, 23 of which were detected above the $0.05 \mu \mathrm{g} / \mathrm{L}$ common reporting limit. Toluene was detected in 94 percent of the samples and was the most frequently detected VOC. Acetone was the VOC detected in the highest concentration, at a maximum of $20 \mu \mathrm{g} / \mathrm{L}$ (estimated value). Toluene was detected at a maximum concentration of $3.15 \mu \mathrm{g} / \mathrm{L}$ in water from site 2 , exceeding the aquatic-life criterion of $2 \mu \mathrm{g} / \mathrm{L}$ (Canadian Council of Ministers of the Environment, 2001). It was the only VOC that exceeded established aquatic-life criteria in samples from sites 1 and 2 .

Fuel-related BTEX compounds (benzene, toluene, ethyl benzene, and the xylenes) were the most frequently detected group of VOCs at site 2 , followed closely by solvents. Other VOCs detected are used in organic synthesis, fumigation, and plastics manufacturing. VOC detections increased slightly with increased dissolved organic carbon concentration and decreased slightly with increasing water temperature (fig. 20). The coefficients of determination $\left(\mathrm{R}^{2}\right)$ for the trends shown are small, 0.28 for graph $\mathrm{A}$ and 0.15 for graph B. The number of VOC detections in samples from site 2 was greatest in samples collected during base-flow periods in the late fall to spring and during storms.

\section{Effect of Storms}

Nutrients and pesticides may accumulate on impermeable surfaces in an urban area either through runoff from lawns and gardens or by direct application. Runoff during storms provides a path for these constituents to reach Little Cottonwood Creek and the Jordan River. Because of the importance of storm runoff to the water quality of Little Cottonwood Creek and the small chance of storms being sampled during fixed-interval sampling, several additional samples were collected at the fixed sites during storms (fig. 5).

At sites 1 and 2, maximum concentrations of many constituents including chloride, sodium, total phosphorus, total nitrogen, and the pesticides prometon, carbaryl, and diazinon were detected in samples collected during storms. Elevated concentrations during storms, often coupled with streamflow that is one to two orders of magnitude higher than base flow, resulted in substantial loads of these constituents in the urban reach of Little Cottonwood Creek.

\section{Spring and Summer}

Spring and summer storms are relatively short in duration, typically less than 4 to 6 hours. The hydrograph associated with a typical spring or summer storm in the Little Cottonwood Creek basin is characterized by a steep, rising limb, a peak of short duration, and a gradually declining, recession limb.

Elevated concentrations of nutrients and pesticides in samples collected during spring and summer storms at sites 1 and 2 indicate that accumulations of these constituents in the urban area are being transported to the stream in storm runoff. 
Table 5. Summary of pesticides analyzed for by gas chromatography/mass spectrometry and detected in water samples collected from sites 1 and 2 on Little Cottonwood Creek, near Salt Lake City, Utah

[Concentration reported in $\mu \mathrm{g} / \mathrm{L}$, micrograms per liter; e, estimated value; -, not established; concentrations in bold italics exceed aquatic-life criterion]

\begin{tabular}{|c|c|c|c|c|c|c|c|c|}
\hline \multirow{3}{*}{ Pesticide } & \multirow[b]{2}{*}{$\begin{array}{c}\text { Number of } \\
\text { samples }\end{array}$} & \multicolumn{2}{|c|}{ Concentration } & \multicolumn{4}{|c|}{ Detections } & \multirow{3}{*}{$\begin{array}{l}\text { Aquatic-life } \\
\text { criterion }\end{array}$} \\
\hline & & Maximum & Median & $\begin{array}{c}\text { Total } \\
\text { (including } \\
\text { estimated } \\
\text { values) }\end{array}$ & $\begin{array}{l}\text { Frequency } \\
\text { (percent) }\end{array}$ & $\begin{array}{c}\text { Above common } \\
\text { reporting limit of } \\
0.01 \mu \mathrm{g} / \mathrm{L}\end{array}$ & $\begin{array}{l}\text { Frequency } \\
\text { (percent) }\end{array}$ & \\
\hline & \multicolumn{7}{|c|}{$\begin{array}{c}\text { Site } 1 \\
\text { (Little Cottonwood Creek at Crestwood Park) }\end{array}$} & \\
\hline Atrazine & 9 & 0.004 & 0.003 & 4 & 44 & 0 & 0 & ${ }^{1} 1.8$ \\
\hline Benefin & 9 & .010 & .003 & 4 & 44 & 0 & 0 & - \\
\hline Carbaryl & 9 & .122 & .050 & 4 & 44 & 4 & 44 & ${ }^{1} .2$ \\
\hline Chlorpyrifos & 9 & .010 & .007 & 4 & 44 & 0 & 0 & 2,3.041 \\
\hline Dacthal & 9 & .004 & .004 & 4 & 44 & 0 & 0 & - \\
\hline Deethylatrazine & 9 & $.006 \mathrm{e}$ & $.006 \mathrm{e}$ & 1 & 11 & 0 & 0 & \\
\hline Diazinon & 9 & .196 & .086 & 7 & 78 & 6 & 67 & ${ }^{3} .08$ \\
\hline EPTC & 9 & .104 & .104 & 1 & 11 & 1 & 11 & ${ }^{1} 10$ \\
\hline Malathion & 9 & .245 & .204 & 3 & 33 & 3 & 33 & ${ }^{3} .1$ \\
\hline Pendimethalin & 9 & .108 & .101 & 4 & 44 & 3 & 33 & - \\
\hline Prometon & 9 & .978 & .125 & 7 & 78 & 7 & 78 & - \\
\hline Tebuthiuron & 9 & $.008 \mathrm{e}$ & $.008 \mathrm{e}$ & 1 & 11 & 0 & 0 & ${ }^{1} 1.6$ \\
\hline Trifluralin & 9 & .004 & .003 & 3 & 33 & 0 & 0 & ${ }^{1} .2$ \\
\hline \multicolumn{9}{|c|}{$\begin{array}{c}\text { Site 2 } \\
\text { (Little Cottonwood Creek at Jordan River) }\end{array}$} \\
\hline Alachlor & 42 & .024 & .024 & 1 & 2 & 1 & 2 & - \\
\hline Atrazine & 42 & .130 & .010 & 32 & 76 & 16 & 38 & ${ }^{1} 1.8$ \\
\hline Benefin & 42 & $.002 \mathrm{e}$ & $.002 \mathrm{e}$ & 1 & 2 & 0 & 0 & - \\
\hline Carbaryl & 42 & .411 & .021 & 28 & 67 & 21 & 50 & ${ }^{1} .2$ \\
\hline Chlorpyrifos & 42 & .007 & $.005 \mathrm{e}$ & 3 & 7 & 0 & 0 & ${ }^{2,3} .041$ \\
\hline Dacthal & 42 & .027 & .005 & 19 & 45 & 3 & 7 & - \\
\hline Deethylatrazine & 42 & .022 & $.005 \mathrm{e}$ & 19 & 45 & 4 & 10 & - \\
\hline Diazinon & 42 & .343 & .024 & 38 & 90 & 27 & 64 & ${ }^{3} .08$ \\
\hline EPTC & 42 & .033 & $.003 \mathrm{e}$ & 6 & 14 & 1 & 2 & ${ }^{1} 10$ \\
\hline Fonofos & 42 & .015 & .015 & 1 & 2 & 1 & 2 & - \\
\hline Malathion & 42 & .144 & .014 & 14 & 33 & 9 & 21 & ${ }^{3} .1$ \\
\hline Metolachlor & 42 & $.004 \mathrm{e}$ & $.004 \mathrm{e}$ & 1 & 2 & 0 & 0 & ${ }^{1} 7.8$ \\
\hline Napropamide & 42 & .048 & .038 & 6 & 14 & 5 & 12 & - \\
\hline Pendimethalin & 42 & .174 & .026 & 15 & 36 & 15 & 36 & - \\
\hline Prometon & 42 & 5.61 & .034 & 40 & 95 & 33 & 79 & - \\
\hline Simazine & 42 & .419 & $.004 \mathrm{e}$ & 9 & 21 & 2 & 5 & ${ }^{1} 10$ \\
\hline Tebuthiuron & 42 & $.69 \mathrm{e}$ & $.016 \mathrm{e}$ & 15 & 36 & 11 & 26 & ${ }^{1} 1.6$ \\
\hline Trifluralin & 42 & $.004 \mathrm{e}$ & $.002 \mathrm{e}$ & 7 & 17 & 0 & 0 & ${ }^{1} .2$ \\
\hline
\end{tabular}

${ }^{1}$ Canadian Government aquatic-life guidelines (Canadian Council of Ministers of the Environment, 2001).

${ }^{2}$ U.S. Environmental Protection Agency chronic aquatic-life guidelines (1999).

${ }^{3}$ Great Lakes water-quality objectives (International Joint Commission, United States and Canada, 1989). 

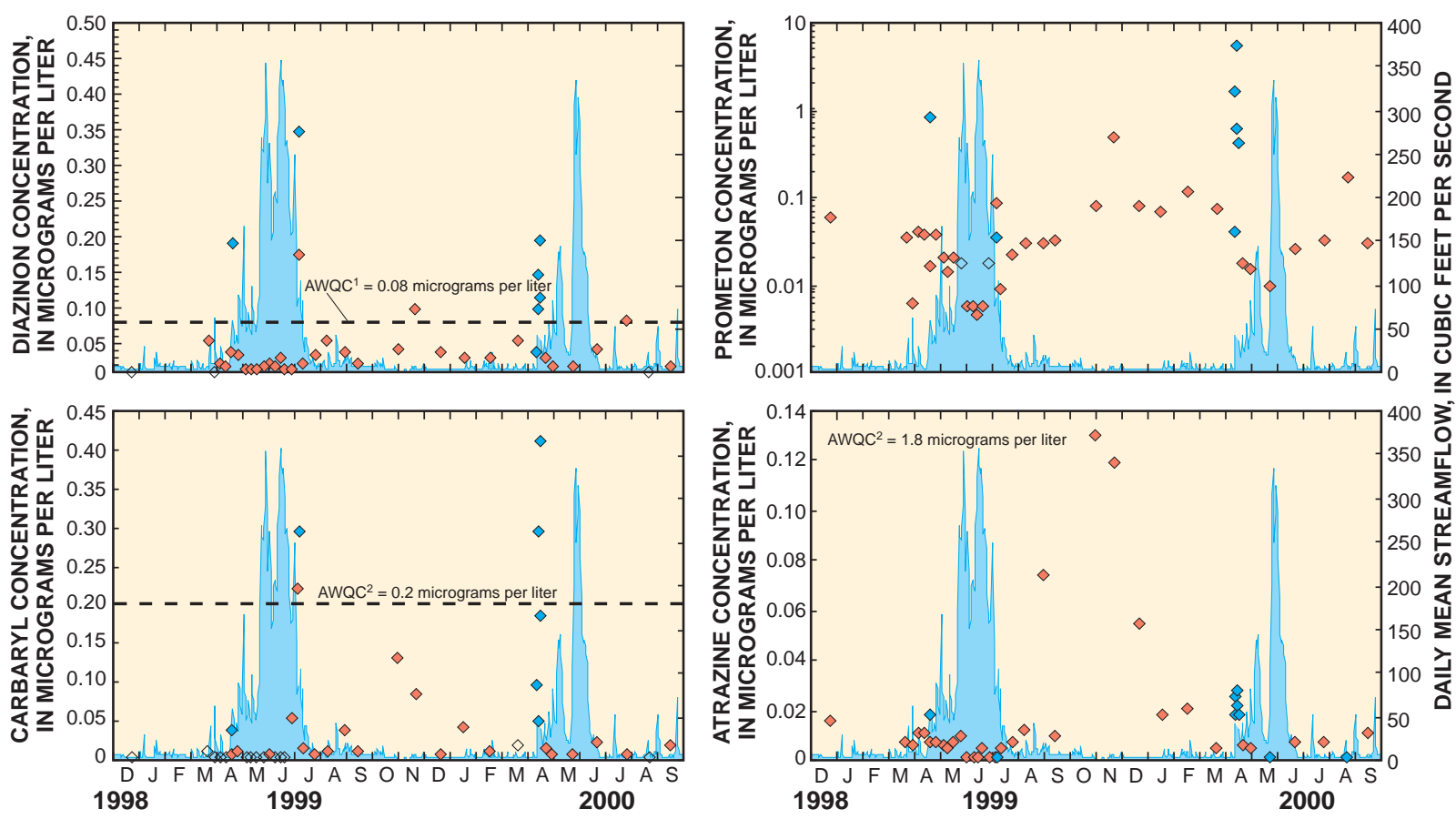

EXPLANATION

Streamflow

AWQC ${ }^{1}$ Ambient Water Quality Criteria for protection of aquatic life (International Joint Commission, United States and Canada, 1989) AWQC2 Ambient Water Quality Criteria (Canadian Council of Ministers of the Environment, 2001)

$\diamond \quad$ Sample-fixed-interval

$\diamond \quad$ Sample-storm

$\diamond \quad$ Sample-nondetection

Figure 18. Seasonal variability of selected pesticide concentrations at site 2 on Little Cottonwood Creek, near Salt Lake City, Utah.

A storm on April 14, 2000, deposited 0.50 in. of rain at the Cottonwood Weir, located at the mouth of Little Cottonwood Canyon (fig. 1). The storm, as defined from the streamflow hydrograph, lasted about 6 hours, from about 0730 to 1330 . Streamflow at site 2 increased for about 3 hours from a base flow of $13 \mathrm{ft}^{3} / \mathrm{s}$ to a peak flow of $187 \mathrm{ft}^{3} / \mathrm{s}$ (fig. 21). Three samples were collected during the storm at site 1 and five samples were collected at site 2. Samples were collected during the storm on the streamflow rise, peak, and recession.

Constituent load and mean concentration calculations for sites 1 and 2, and in runoff between sites 1 and 2, during a storm on April 14, 2000, are shown in table 8 . Land use in the drainage basin that contributes water to the reach of Little Cottonwood Creek between sites 1 and 2 is 54 percent residential and 46 percent other urban land uses. The effects of storm runoff from the urban area between sites 1 and 2 on stream quality are shown by the increase in concentration and load of solutes at site 2 .

Mean concentrations for selected nutrients and pesticides in (1) non-storm samples collected at sites 1 and 2, (2) samples collected during the storm of April 14, 2000, at sites 1 and 2, and (3) calculated for runoff between sites 1 and 2 during this storm are shown in figure 22. Nutrients and pesticides are present in much greater concentrations in samples with storm runoff than in non-storm samples. Runoff from urban land cover is a substantial source of nutrients and pesticides to Little Cottonwood Creek. Mean concentrations of total ammonia plus organic nitrogen, total nitrogen (total ammonia + organic nitrogen + nitrite + nitrate), and total phosphorus calculated for runoff between sites 1 and 2 for the April 14, 2000, storm were much 


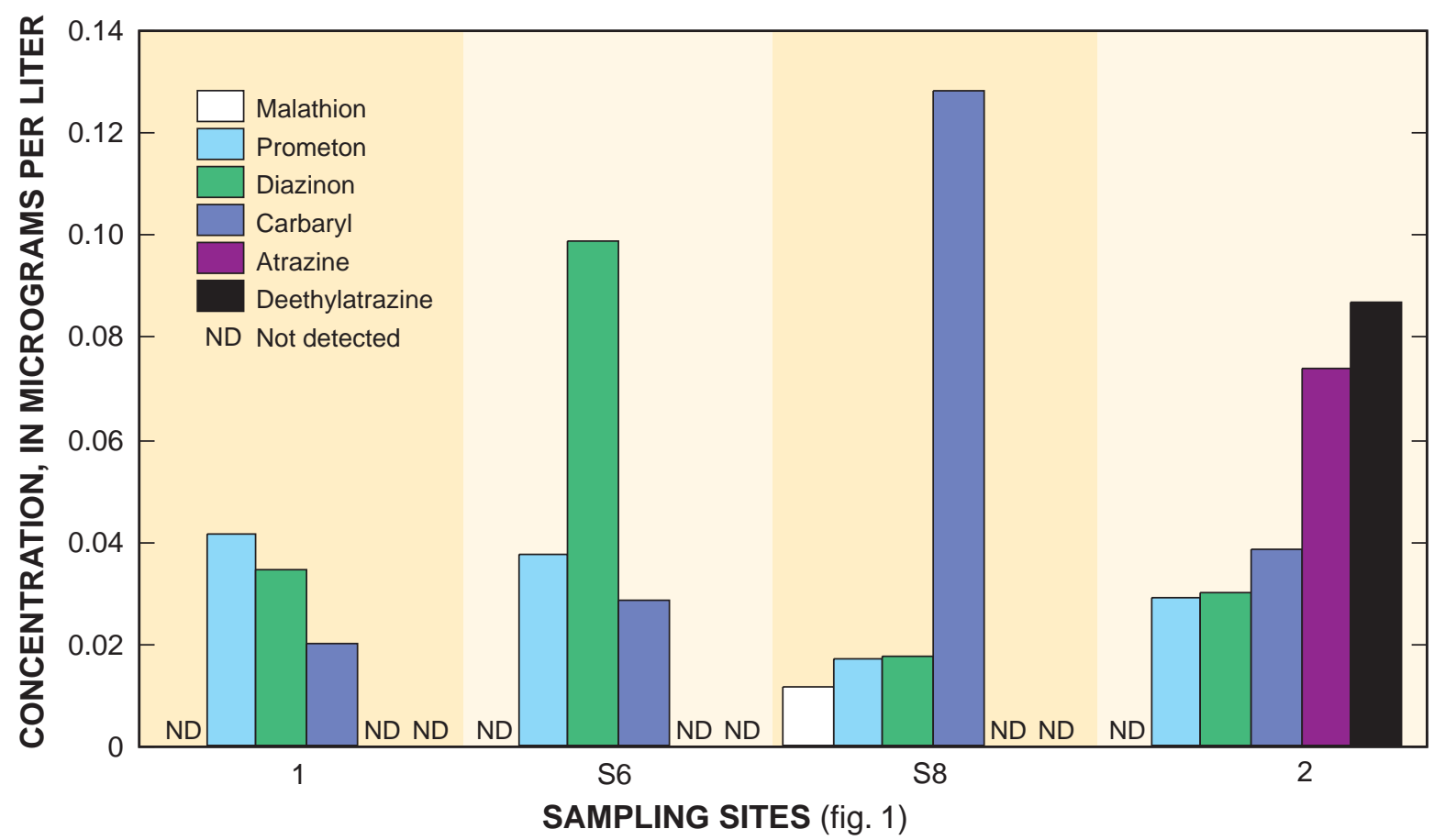

Figure 19. Concentration of selected pesticides at sites 1 and S6 on Little Cottonwood Creek, September 2, 1999 , and sites S8 and 2 on Little Cottonwood Creek, near Salt Lake City, Utah, August 31, 1999.

higher than those measured in non-storm samples from the fixed sites. Similarly, mean concentrations of atrazine, carbaryl, diazinon, and prometon in the runoff from the April 14, 2000, storm were much higher than what was measured in non-storm samples.

Nutrient and pesticide concentrations calculated for runoff to the stream between sites 1 and 2 during the April 14, 2000, storm were generally much higher than mean concentrations calculated for the storm at either site 1 or 2 (table 8). Atrazine, carbaryl, dacthal, and prometon concentrations calculated in runoff between sites 1 and 2 during the April 14, 2000, storm were more than twice the mean concentration calculated for the storm at site 1 and more than 30 percent higher than mean concentrations at site 2 . The calculated concentration of chlorpyrifos, diazinon, and malathion was higher at site 1 and 2 than in the runoff between sites 1 and 2. Concentration of these insecticides was highest at site 1, indicating that for this storm, a significant source of these insecticides was upstream of this site.

\section{Winter}

Parts of the Little Cottonwood Creek drainage basin have a dense network of roads that are salted during winter. Much of this salt runs off into the stream and greatly enhances the sodium and chloride concentration in the stream. Chloride ions are conservative, moving with water without being retarded or lost. Accordingly, almost all chloride ions that enter the soil and ground water in the Little Cottonwood Creek drainage basin have the potential to reach surface water. Specific-conductance values and chloride concentration increased in the urbanized reach of Little Cottonwood Creek during and following most winter storms. The USEPA recommends that a chloride concentration of $860 \mathrm{mg} / \mathrm{L}$ should not be exceeded for more than 1 hour every 3 years, and that a 4-day average chloride concentration of $230 \mathrm{mg} / \mathrm{L}$ should not be exceeded more than once every 3 years (U.S. Environmental Protection Agency, 1988). The second order polynomial regression equation for chloride (fig. 8) provided an estimate of chloride concentration at 
Table 6. Minimum reporting level of volatile organic compounds analyzed for in water samples collected at fixed sites on Little Cottonwood Creek, near Salt Lake City, Utah

[CAS number, Chemical Abstract Service number; MRL, minimum reporting level; $\mu \mathrm{g} / \mathrm{L}$, micrograms per liter]

\begin{tabular}{|c|c|c|c|c|}
\hline Parameter code name & $\begin{array}{l}\text { Parameter } \\
\text { code }\end{array}$ & $\begin{array}{l}\text { Preferred compound } \\
\text { name }\end{array}$ & $\begin{array}{c}\text { CAS } \\
\text { number }\end{array}$ & $\underset{(\mu g / L)}{M R L}$ \\
\hline DIISOPROPYL ETHER & 81577 & Diisopropyl ether & $108-20-3$ & 0.098 \\
\hline 1,1,1-TRICHLOROETHANE & 34506 & 1,1,1-Trichloroethane & $71-55-6$ & .032 \\
\hline 1,1,2-TRICHLOROETHANE & 34511 & 1,1,2-Trichloroethane & $79-00-5$ & .064 \\
\hline 1,1-DICHLOROETHANE & 34496 & 1,1-Dichloroethane & $75-34-3$ & .066 \\
\hline 1,1-DICHLOROETHYLENE & 34501 & 1,1-Dichloroethene & $75-35-4$ & .044 \\
\hline 1,1-DICHLOROPROPENE & 77168 & 1,1-Dichloropropene & $563-58-6$ & .026 \\
\hline 1,2,3-TRICHLOROPROPANE & 77443 & 1,2,3-Trichloropropane & $96-18-4$ & .16 \\
\hline 1,2-DIBROMOETHANE & 77651 & 1,2-Dibromoethane & $106-93-4$ & .036 \\
\hline 1,2-DICHLOROETHANE & 32103 & 1,2-Dichloroethane & $107-06-2$ & .13 \\
\hline 1,2-DICHLOROPROPANE & 34541 & 1,2-Dichloropropane & $78-87-5$ & .068 \\
\hline 1,2-TRANSDICHLOROETHENE & 34546 & trans-1,2-Dichloroethene & $156-60-5$ & .032 \\
\hline 2,2-DICHLOROPROPANE & 77170 & 2,2-Dichloropropane & $594-20-7$ & .078 \\
\hline 2-BUTENE, TRANS-1,4-DICHLORO- & 73547 & trans-1,4-Dichloro-2-butene & $110-57-6$ & .7 \\
\hline 2-HEXANONE & 77103 & 2-Hexanone & $591-78-6$ & .7 \\
\hline ACETONE & 81552 & Acetone & $67-64-1$ & 5 \\
\hline ACRYLONITRILE & 34215 & 2-Propenenitrile & $107-13-1$ & 1.2 \\
\hline BENZENE & 34030 & Benzene & $71-43-2$ & .1 \\
\hline BENZENE, 1,2,3-TRICHLORO- & 77613 & 1,2,3-Trichlorobenzene & $87-61-6$ & .27 \\
\hline BENZENE, 1,2,3-TRIMETHYL- & 77221 & 1,2,3-Trimethylbenzene & $526-73-8$ & .12 \\
\hline BENZENE, 1,2,4-TRICHLORO- & 34551 & 1,2,4-Trichlorobenzene & $120-82-1$ & .19 \\
\hline BENZENE, 1,2,4-TRIMETHYL- & 77222 & 1,2,4-Trimethylbenzene & $95-63-6$ & .056 \\
\hline BENZENE, 1,3,5-TRIMETHYL- & 77226 & 1,3,5-Trimethylbenzene & $108-67-8$ & .044 \\
\hline BENZENE, 1,3-DICHLORO- & 34566 & 1,3-Dichlorobenzene & $541-73-1$ & .054 \\
\hline BENZENE, 1,4-DICHLORO- & 34571 & 1,4-Dichlorobenzene & $106-46-7$ & .05 \\
\hline BENZENE, ISOPROPYL- & 77223 & (1-Methylethyl)benzene & $98-82-8$ & .032 \\
\hline BENZENE, N-BUTYL- & 77342 & n-Butylbenzene & $104-51-8$ & .19 \\
\hline BENZENE, N-PROPYL- & 77224 & n-Propylbenzene & $103-65-1$ & .042 \\
\hline BENZENE, O-DICHLORO- & 34536 & 1,2-Dichlorobenzene & $95-50-1$ & .048 \\
\hline BENZENE, SEC-BUTYL- & 77350 & (1-Methylpropyl)benzene & $135-98-8$ & .048 \\
\hline BENZENE, TERT-BUTYL- & 77353 & (1,1-Dimethylethyl)benzene & $98-06-6$ & .1 \\
\hline BROMOBENZENE & 81555 & Bromobenzene & $108-86-1$ & .036 \\
\hline BROMOETHENE & 50002 & Bromoethene & $593-60-2$ & .1 \\
\hline BROMOFORM & 32104 & Tribromomethane & $75-25-2$ & .1 \\
\hline CARBON DISULFIDE & 77041 & Carbon disulfide & $75-15-0$ & .37 \\
\hline CARBONTETRACHLORIDE & 32102 & Tetrachloromethane & $56-23-5$ & .088 \\
\hline CHLOROBENZENE & 34301 & Chlorobenzene & $108-90-7$ & .028 \\
\hline CHLORODIBROMOMETHANE & 32105 & Dibromochloromethane & $124-48-1$ & .18 \\
\hline CHLOROETHANE & 34311 & Chloroethane & $75-00-3$ & .12 \\
\hline CHLOROFORM & 32106 & Trichloromethane & $67-66-3$ & .052 \\
\hline CIS-1,2-DICHLOROETHENE & 77093 & cis-1,2-Dichloroethene & $156-59-2$ & .038 \\
\hline CIS-1,3-DICHLOROPROPENE & 34704 & cis-1,3-Dichloropropene & $10061-01-5$ & .09 \\
\hline DIBROMOCHLOROPROPANE & 82625 & 1,2-Dibromo-3-chloropropane & $96-12-8$ & .21 \\
\hline DIBROMOMETHANE & 30217 & Dibromomethane & $74-95-3$ & .05 \\
\hline DICHLOROBROMOMETHANE & 32101 & Bromodichloromethane & $75-27-4$ & .048 \\
\hline DICHLORODIFLUOROMETHANE & 34668 & Dichlorodifluoromethane & $75-71-8$ & .14 \\
\hline ETHANE, 1,1,1,2-TETRACHLORO- & 77562 & 1,1,1,2-Tetrachloroethane & $630-20-6$ & .044 \\
\hline ETHANE, $1,1,2,2$-TETRACHLORO- & 34516 & 1,1,2,2-Tetrachloroethane & $79-34-5$ & .13 \\
\hline ETHANE, HEXACHLORO- & 34396 & 1,1,1,2,2,2-Hexachloroethane & $67-72-1$ & .36 \\
\hline ETHER, ETHYL- & 81576 & Diethyl ether & $60-29-7$ & .17 \\
\hline ETHER, TERT-BUTYL ETHYL- & 50004 & Ethyl tert-butyl ether & $637-92-3$ & .054 \\
\hline ETHER, TERT-PENTYL METHYL- & 50005 & tert-Amyl methyl ether & $994-05-8$ & .11 \\
\hline ETHYLBENZENE & 34371 & Ethylbenzene & $100-41-4$ & .03 \\
\hline
\end{tabular}


Table 6. Minimum reporting level of volatile organic compounds analyzed for in water samples collected at fixed sites on Little Cottonwood Creek, near Salt Lake City, Utah—Continued

\begin{tabular}{|c|c|c|c|c|}
\hline Parameter code name & $\begin{array}{l}\text { Parameter } \\
\text { code }\end{array}$ & $\begin{array}{l}\text { Preferred compound } \\
\text { name }\end{array}$ & $\begin{array}{c}\text { CAS } \\
\text { number }\end{array}$ & $\begin{array}{l}\text { MRL } \\
(\mu \mathrm{g} / \mathrm{L})\end{array}$ \\
\hline FREON 113 & 77652 & 1,1,2-Trichloro-1,2,2-trifluoroethane & 76-13-1 & .032 \\
\hline FURAN, TETRAHYDRO- & 81607 & Tetrahydrofuran & $109-99-9$ & 9 \\
\hline HEXACHLOROBUTADIENE & 39702 & Hexachlorobutadiene & $87-68-3$ & .14 \\
\hline ISODURENE & 50000 & 1,2,3,5-Tetramethylbenzene & $527-53-7$ & .2 \\
\hline METHACRYLATE METHYL & 81597 & Methyl methacrylate & $80-26-6$ & .35 \\
\hline METHACRYLATE, ETHYL- & 73570 & Ethyl methacrylate & $97-63-2$ & .28 \\
\hline METHACRYLONITRILE & 81593 & Methyl acrylonitrile & $126-98-7$ & .57 \\
\hline METHANE, BROMOCHLORO- & 77297 & Bromochloromethane & $74-97-5$ & .044 \\
\hline METHYL ACRYLATE & 49991 & Methyl acrylate & $96-33-3$ & 1.4 \\
\hline METHYL IODIDE & 77424 & Iodomethane & $74-88-4$ & .21 \\
\hline METHYL TERTIARY-BUTYL ETHER (MTBE) & 78032 & Methyl tert-butyl ether & $1634-04-4$ & .17 \\
\hline METHYLBROMIDE & 34413 & Bromomethane & 74-83-9 & .15 \\
\hline METHYLCHLORIDE & 34418 & Chloromethane & $74-87-3$ & .25 \\
\hline METHYLENECHLORIDE & 34423 & Dichloromethane & $75-09-2$ & .38 \\
\hline METHYLETHYLKETONE & 81595 & 2-Butanone & 78-93-3 & 1.6 \\
\hline METHYLISOBUTYLKETONE & 78133 & 4-Methyl-2-pentanone & $108-10-1$ & .37 \\
\hline M-XYLENE/P-XYLENE & 85795 & $1,3 \&$ 1,4-Dimethylbenzene & $106-42-3: 108-38-3$ & .06 \\
\hline NAPHTHALENE & 34696 & Naphthalene & $91-20-3$ & .25 \\
\hline O-CHLOROTOLUENE & 77275 & 1-Chloro-2-methylbenzene & $95-49-8$ & .042 \\
\hline O-XYLENE & 77135 & 1,2-Dimethylbenzene & $95-47-6$ & .06 \\
\hline P-ISOPROPYLTOLUENE & 77356 & 1-Isopropyl-4-methylbenzene & $99-87-6$ & .11 \\
\hline PREHNITENE & 49999 & 1,2,3,4-Tetramethylbenzene & $488-23-3$ & .23 \\
\hline PROPANE, 1,3-DICHLORO- & 77173 & 1,3-Dichloropropane & $142-28-9$ & .12 \\
\hline PROPENE, 3-CHLORO- & 78109 & 3-Chloro-1-propene & $107-05-1$ & .2 \\
\hline STYRENE & 77128 & Ethenylbenzene & $100-42-5$ & .042 \\
\hline TETRACHLOROETHYLENE & 34475 & Tetrachloroethene & $127-18-4$ & .1 \\
\hline TOLUENE & 34010 & Methylbenzene & $108-88-3$ & .05 \\
\hline TOLUENE, O-ETHYL- & 77220 & 2-Ethyltoluene & $611-14-3$ & .1 \\
\hline TOLUENE, P-CHLORO- & 77277 & 1-Chloro-4-methylbenzene & $106-43-4$ & .056 \\
\hline TRANS-1,3-DICHLOROPROPENE & 34699 & trans-1,3-Dichloropropene & $10061-02-6$ & .13 \\
\hline TRICHLOROETHYLENE & 39180 & Trichloroethene & 79-01-6 & .038 \\
\hline TRICHLOROFLUOROMETHANE & 34488 & Trichlorofluoromethane & $75-69-4$ & .09 \\
\hline VINYLCHLORIDE & 39175 & Chloroethene & 75-01-4 & .11 \\
\hline 1,3, and 1,4-DIMETHYLBENZENE & 85795 & m/P-Xylene (Dimethyl benzene) & $108-38-3$ & .06 \\
\hline
\end{tabular}


Table 7. Summary of volatile organic compounds detected in water samples from sites 1 and 2 on Little Cottonwood Creek, near Salt Lake City, Utah [Concentration reported in $\mu \mathrm{g} / \mathrm{L}$, micrograms per liter; <, less than; e, estimated value; —, not established; concentrations in bold italics exceed aquatic-life criterion]

\begin{tabular}{|c|c|c|c|c|c|c|c|}
\hline \multirow[b]{2}{*}{ Constituent } & \multirow[b]{2}{*}{$\begin{array}{l}\text { Number of } \\
\text { samples }\end{array}$} & \multicolumn{2}{|c|}{ Concentration } & \multicolumn{3}{|c|}{ Detections } & \multirow[b]{2}{*}{$\begin{array}{l}\text { Aquatic- } \\
\text { life } \\
\text { criterion }\end{array}$} \\
\hline & & Maximum & Median & $\begin{array}{c}\text { Total } \\
\text { (including } \\
\text { estimated } \\
\text { values) }\end{array}$ & $\begin{array}{l}\text { Above common } \\
\text { reporting limit } \\
\text { of } 0.05 \mu \mathrm{g} / \mathrm{L}\end{array}$ & $\begin{array}{l}\text { Frequency } \\
\text { (percent) }\end{array}$ & \\
\hline \multicolumn{8}{|c|}{$\begin{array}{c}\text { Site } 1 \\
\text { (Little Cottonwood Creek at Crestwood Park) }\end{array}$} \\
\hline Benzene & 2 & $0.009 \mathrm{e}$ & 0.009 & 1 & 0 & 0 & 1370 \\
\hline Chloroform & 2 & $.055 \mathrm{e}$ & .034 & 2 & 1 & 50 & ${ }^{1} 1.8$ \\
\hline Toluene & 2 & $.011 \mathrm{e}$ & .011 & 1 & 0 & 0 & $1_{2}$ \\
\hline \multicolumn{8}{|c|}{$\begin{array}{c}\text { Site } 2 \\
\text { (Little Cottonwood Creek at Jordan River) }\end{array}$} \\
\hline 1,2,4-trimethyl-benzene & 32 & 0.662 & 0.025 & 19 & 3 & 9 & - \\
\hline 1,3,5-trimethyl-benzene & 32 & .172 & .148 & 3 & 3 & 9 & - \\
\hline 1,4-dichloro-benzene & 32 & $.046 \mathrm{e}$ & .027 & 2 & 0 & 0 & $1_{4}$ \\
\hline Acetone & 32 & $20.0 \mathrm{e}$ & 3.52 & 19 & 19 & 59 & - \\
\hline Benzene & 32 & .212 & .031 & 27 & 2 & 6 & ${ }^{1} 370$ \\
\hline 1,2,3-trimethyl-benzene & 32 & $.168 \mathrm{e}$ & .153 & 4 & 3 & 9 & - \\
\hline Dichlorobromomethane & 32 & $.016 \mathrm{e}$ & .014 & 2 & 0 & 0 & ${ }^{2} 11,000$ \\
\hline Bromoform & 32 & .156 & .144 & 2 & 2 & 6 & ${ }^{2} 11,000$ \\
\hline Carbon Disulfide & 32 & $.084 \mathrm{e}$ & .076 & 3 & 2 & 6 & ${ }^{3} 2$ \\
\hline Chloroform & 32 & .144 & .023 & 29 & 6 & 19 & ${ }^{1} 1.8$ \\
\hline Cis-1, 2-dichloroethene & 32 & $.037 \mathrm{e}$ & .021 & 9 & 0 & 0 & ${ }^{2} 11,600$ \\
\hline Ethylbenzene & 32 & $.132 \mathrm{e}$ & .012 & 20 & 3 & 9 & ${ }^{1} 90$ \\
\hline Isodurene & 32 & $.135 \mathrm{e}$ & .125 & 3 & 3 & 9 & - \\
\hline m/p-Xylene & 32 & .692 & .041 & 24 & 10 & 31 & - \\
\hline Methylethylketone & 32 & $3.03 \mathrm{e}$ & 1.04 & 11 & 11 & 34 & - \\
\hline Methylisobutylketone & 32 & $1.48 \mathrm{e}$ & .884 & 12 & 12 & 38 & - \\
\hline Methylchloride & 32 & $.061 \mathrm{e}$ & .055 & 3 & 3 & 9 & - \\
\hline Methylenechloride & 32 & $.038 \mathrm{e}$ & .021 & 12 & 0 & 0 & ${ }^{2} 11,000$ \\
\hline Methyl Tertiary-butyl Ether (MTBE) & 32 & $.075 \mathrm{e}$ & .043 & 13 & 3 & 9 & - \\
\hline N-butyl-benzene & 32 & $.014 \mathrm{e}$ & .014 & 3 & 0 & 0 & - \\
\hline N-propyl-benzene & 32 & $.052 \mathrm{e}$ & .049 & 3 & 1 & 3 & - \\
\hline P-isopropyltoluene & 32 & $.107 \mathrm{e}$ & .015 & 12 & 3 & 9 & - \\
\hline Styrene & 32 & .103 & .025 & 13 & 1 & 3 & 72 \\
\hline Tetrachloroethylene & 32 & $.082 \mathrm{e}$ & .012 & 15 & 1 & 3 & ${ }^{1} 111$ \\
\hline Toluene, O-ethyl- & 32 & $.100 \mathrm{e}$ & .091 & 3 & 3 & 9 & - \\
\hline Toluene & 32 & 3.15 & .115 & 32 & 30 & 94 & ${ }^{1} 2$ \\
\hline O-xylene & 32 & .355 & .022 & 19 & 3 & 9 & - \\
\hline Trichloroethylene & 32 & $.071 \mathrm{e}$ & .036 & 7 & 2 & 6 & ${ }^{1} 21$ \\
\hline
\end{tabular}

${ }^{1}$ Canadian Government aquatic-life guidelines (Canadian Council of Ministers of the Environment, 2001).

${ }^{2}$ U.S. Environmental Protection Agency freshwater aquatic-life acute criteria/guidelines (Rowe and others, 1997).

${ }^{3}$ U.S. Environmental Protection Agency freshwater aquatic-life chronic criteria/guidelines (Rowe and others, 1997). 


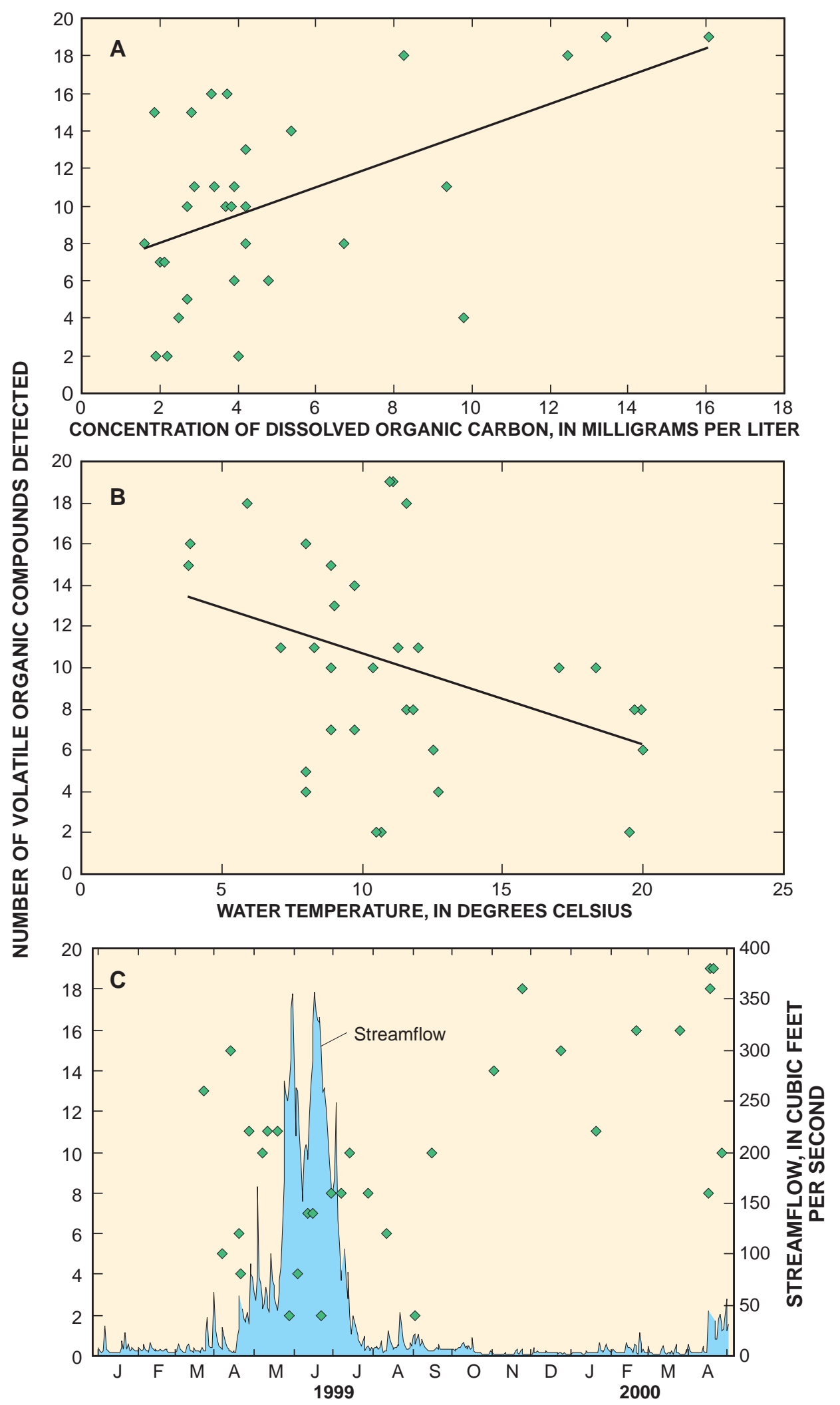

Figure 20. Relation of number of volatile organic compounds detected to (A) dissolved organic carbon, (B) water temperature, and (C) seasonal streamflow at site 2 on Little Cottonwood Creek, near Salt Lake City, Utah. 
Table 8. Load and mean concentration of selected constituents at sites 1 and 2, and in runoff between sites 1 and 2, on Little Cottonwood Creek, near Salt Lake City, Utah, calculated for a storm on April 14, 2000

[Values in table are rounded from calculated values for load and concentration; mg/L, milligrams per liter; $\mathrm{kg}$, kilograms; $\mu \mathrm{g} / \mathrm{L}$, micrograms per liter; g, grams]

\begin{tabular}{|c|c|c|c|c|c|c|c|c|}
\hline \multirow{2}{*}{ Constituent } & \multicolumn{2}{|c|}{ Mean concentration ${ }^{1,2}$} & \multicolumn{2}{|c|}{$\begin{array}{l}\text { Flow-weighted } \\
\text { storm load }\end{array}$} & \multicolumn{2}{|c|}{$\begin{array}{l}\text { Runoff between sites } \\
1 \text { and } 2\end{array}$} & \multicolumn{2}{|c|}{$\begin{array}{l}\text { Comparison of runoff } \\
\text { concentration to fixed sites } \\
\text { (percent) }\end{array}$} \\
\hline & Site 1 & Site 2 & Site 1 & Site 2 & Load $^{3}$ & $\begin{array}{c}\text { Mean } \\
\text { concen- } \\
\text { tration }\end{array}$ & Site 1 & Site 2 \\
\hline & (mg/L) & (mg/L) & (kg) & (kg) & (kg) & (mg/L) & & \\
\hline Dissolved organic carbon & 5.73 & 10.9 & 125 & 492 & 367 & 15.7 & 274 & 144 \\
\hline $\begin{array}{l}\text { Dissolved solids, residue on } \\
\text { evaporation }\end{array}$ & 107 & 185 & 2,340 & 8,380 & 6,040 & 258 & 241 & 139 \\
\hline \multicolumn{9}{|c|}{ Major Ions } \\
\hline & (mg/L) & (mg/L) & (kg) & (kg) & (kg) & $(\mathrm{mg} / \mathrm{L})$ & & \\
\hline Calcium & 13.2 & 20.5 & 290 & 927 & 637 & 27.2 & 206 & 133 \\
\hline Magnesium & 2.60 & 5.34 & 56.8 & 242 & 185 & 7.90 & 304 & 148 \\
\hline Potassium & 1.33 & 2.66 & 29.1 & 121 & 91.6 & 3.91 & 294 & 147 \\
\hline Sodium & 17.8 & 32.9 & 390 & 1,490 & 1,100 & 46.9 & 263 & 143 \\
\hline Bicarbonate & 41.5 & 68.7 & 909 & 3,110 & 2,200 & 94.1 & 227 & 137 \\
\hline Chloride & 30.0 & 51.3 & 657 & 2,330 & 1,670 & 71.2 & 237 & 139 \\
\hline Fluoride & .170 & .161 & 3.71 & 7.29 & 3.58 & .153 & 90 & 95 \\
\hline Silica & 3.33 & 3.01 & 72.9 & 136 & 63.6 & 2.71 & 81 & 90 \\
\hline Sulfate & 8.91 & 16.9 & 195 & 765 & 570 & 24.3 & 273 & 144 \\
\hline \multicolumn{9}{|c|}{ Nutrients } \\
\hline & (mg/L) & (mg/L) & (kg) & (kg) & (kg) & (mg/L) & & \\
\hline Nitrogen, ammonia, dissolved & .174 & .377 & 3.82 & 17.1 & 13.3 & .567 & 326 & 150 \\
\hline $\begin{array}{l}\text { Nitrogen, organic plus } \\
\text { ammonia, dissolved }\end{array}$ & .479 & 1.09 & 10.5 & 49.4 & 38.9 & 1.66 & 347 & 152 \\
\hline $\begin{array}{l}\text { Nitrogen, organic plus } \\
\quad \text { ammonia, total }\end{array}$ & 2.95 & 6.06 & 64.6 & 275 & 210 & 8.96 & 304 & 148 \\
\hline Nitrogen, nitrite, dissolved & .014 & .044 & .301 & 1.99 & 1.69 & .072 & 514 & 164 \\
\hline Nitrogen, nitrate, dissolved & .257 & .428 & 5.62 & 19.4 & 13.8 & .588 & 229 & 137 \\
\hline $\begin{array}{l}\text { Nitrogen, nitrite plus nitrate, } \\
\text { dissolved }\end{array}$ & .271 & .472 & 5.92 & 21.4 & 15.5 & .660 & 244 & 140 \\
\hline Nitrogen, total & 3.18 & 6.47 & 69.5 & 293 & 224 & 9.55 & 300 & 148 \\
\hline $\begin{array}{l}\text { Phosphorus, orthophosphate, } \\
\text { dissolved }\end{array}$ & .046 & .058 & 1.01 & 2.63 & 1.62 & .069 & 150 & 119 \\
\hline Phosphorus, dissolved & .066 & .084 & 1.44 & 3.80 & 2.36 & .101 & 153 & 120 \\
\hline Phosphorus, total & .615 & 1.25 & 13.5 & 56.5 & 43.0 & 1.84 & 299 & 147 \\
\hline \multicolumn{9}{|c|}{ Trace elements } \\
\hline & $(\mu \mathrm{g} / \mathrm{L})$ & $(\mu \mathrm{g} / \mathrm{L})$ & (g) & (g) & (g) & $(\mu \mathrm{g} / \mathrm{L})$ & & \\
\hline Aluminum & 12.4 & 14.1 & 272 & 639 & 367 & 15.6 & 126 & 111 \\
\hline Arsenic & 1.62 & 12.8 & 35.5 & 582 & 547 & 23.3 & 1,440 & 182 \\
\hline Barium & 27.8 & 35.1 & 609 & 1,590 & 983 & 41.9 & 151 & 119 \\
\hline Copper & 4.26 & 3.00 & 93.2 & 136 & 42.7 & 1.82 & 43 & 61 \\
\hline Iron & 17.0 & 68.3 & 371 & 3,100 & 2,730 & 116 & 682 & 170 \\
\hline Manganese & 8.74 & 51.6 & 191 & 2,340 & 2,150 & 91.7 & 1,050 & 178 \\
\hline Molybdenum & 1.56 & 3.17 & 34.2 & 144 & 109 & 4.66 & 299 & 147 \\
\hline Uranium, natural & 1.26 & 2.48 & 27.6 & 112 & 84.7 & 3.61 & 287 & 146 \\
\hline Zinc & 28.1 & 18.9 & 616 & 856 & 240 & 10.2 & 36 & 54 \\
\hline \multicolumn{9}{|c|}{ Pesticides } \\
\hline & $(\mu \mathbf{g} / \mathbf{L})$ & $(\mu \mathrm{g} / \mathrm{L})$ & (g) & (g) & (g) & $(\mu \mathrm{g} / \mathrm{L})$ & & \\
\hline Atrazine & .001 & .022 & .031 & .976 & .944 & .040 & 4,000 & 182 \\
\hline Carbaryl & .043 & .250 & .951 & 11.3 & 10.4 & .443 & 1,030 & 177 \\
\hline Chlorpyrifos & .007 & .003 & .163 & .129 & 0 & 0 & 0 & 0 \\
\hline Dacthal & .004 & .006 & .089 & .282 & .193 & .008 & 200 & 133 \\
\hline Diazinon & .159 & .140 & 3.48 & 6.36 & 2.88 & .123 & 77 & 88 \\
\hline Malathion & .165 & .064 & 3.61 & 2.89 & 0 & 0 & 0 & 0 \\
\hline Prometon & .471 & 1.18 & 10.3 & 53.3 & 43.0 & 1.84 & 391 & 156 \\
\hline
\end{tabular}

${ }^{1}$ Stream discharge for this storm was $2.19 \times 10^{7}$ liters at site 1 and $4.53 \times 10^{7}$ liters at site 2 .

${ }^{2}$ Calculated as ((load $\left.\times 10^{6}\right) /$ discharge $)$.

${ }^{3}$ Calculated as (site 2 load - sitel load). 


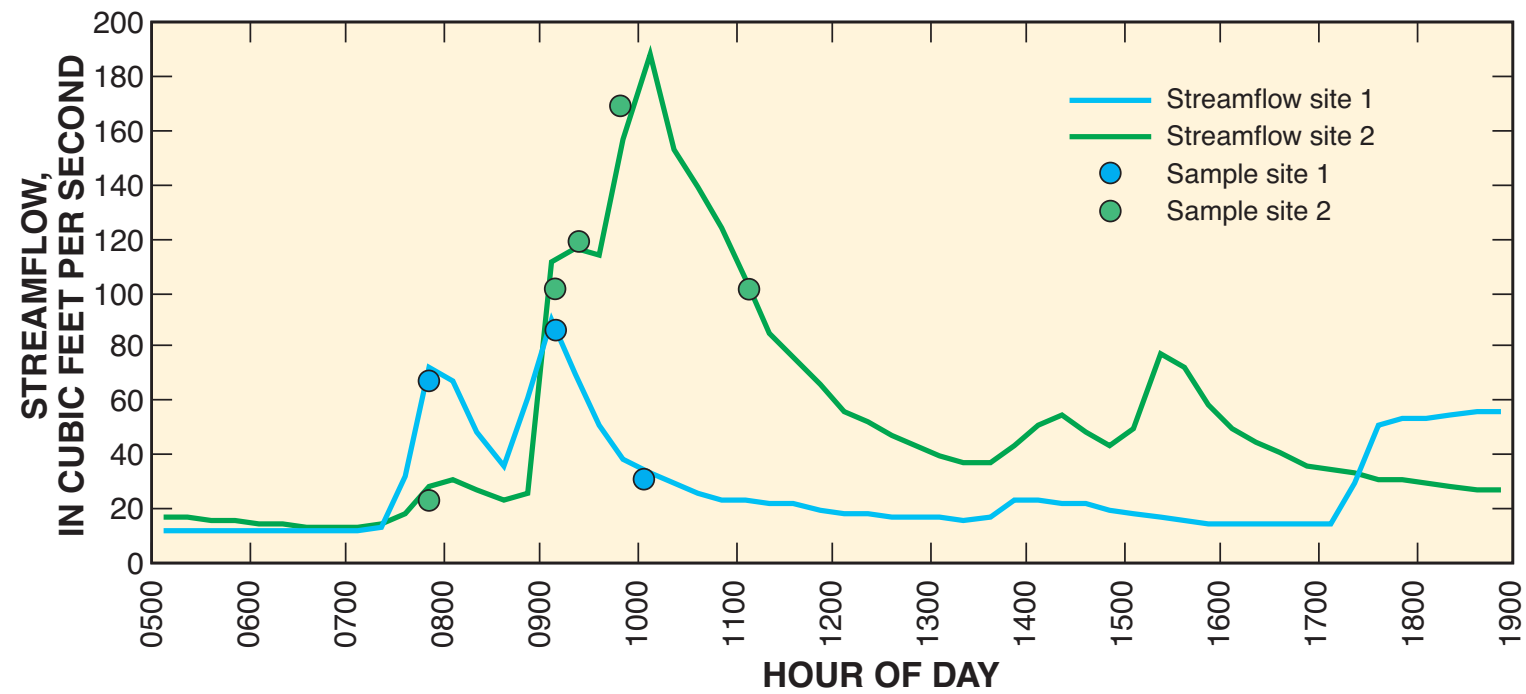

Figure 21. Streamflow and temporal distribution of water-quality samples at sites 1 and 2 on Little Cottonwood Creek, near Salt Lake City, Utah, during storm on April 14, 2000.

site 2 based on specific-conductance values. With this regression equation, a chloride concentration of 860 $\mathrm{mg} / \mathrm{L}$ corresponds to a specific-conductance value of $3,450 \mu \mathrm{S} / \mathrm{cm}$. Because daily mean specific-conductance values exceeded $3,450 \mu \mathrm{S} / \mathrm{cm}$ about 9 percent of the time during December through March in water years 1999 and 2000, the daily mean chloride concentration probably exceeded the USEPA acute criterion of 860 $\mathrm{mg} / \mathrm{L}$ about the same amount of time. On the basis of the regression equation (fig. 8), a chloride concentration of $230 \mathrm{mg} / \mathrm{L}$ corresponds to specific conductance of $1,410 \mu \mathrm{S} / \mathrm{cm}$. Because the 4-day average specific-conductance value exceeded 1,410 $\mu \mathrm{S} / \mathrm{cm}$ more than 30 times at site 2 during 1999-2000, the 4-day average chloride concentration probably exceeded the USEPA chronic criterion of $230 \mathrm{mg} / \mathrm{L}$ about the same amount of time.

Environment Canada (2001) concluded that very high concentrations of chloride may cause acute and chronic toxicity in aquatic organisms. Lower concentrations may affect community structure, diversity, and productivity. Periphyton samples were collected at sites 1 and 2 during summer 2000. About 5 percent of diatom taxa identified from the sample collected at site 1 was very tolerant of salinity. About 40 percent of diatom taxa identified from the sample collected at site 2 was very tolerant of salinity (Elise Giddings, U.S. Geological Survey, written commun.,
2002). The higher percentage of algae in taxa more tolerant of salinity at site 2 may be a result of sodium chloride, probably from road salts, entering the stream in ground-water discharge and surface runoff between sites 1 and 2.

\section{SUMMARY}

The Great Salt Lake Basins study unit of the USGS National Water-Quality Assessment program is 1 of 51 study units designed to describe the status of and trends in the quality of the Nation's ground-water and surface-water resources. The program is intended to develop an understanding of the natural and human factors that affect those resources. A fixed-site assessment is a component of the surface-water study design used to assess the spatial and temporal distribution of selected constituent groups. Two fixed sites were established on Little Cottonwood Creek in Utah to help determine the influence of urbanization on the water quality of the stream. The objectives of this study were to (1) describe the hydrology and water quality in an urban reach of Little Cottonwood Creek from October 1, 1998, to September 30, 2000, (2) relate changes in water quality to constituent sources, and (3) relate constituent concentrations to established aquatic-life criteria. 

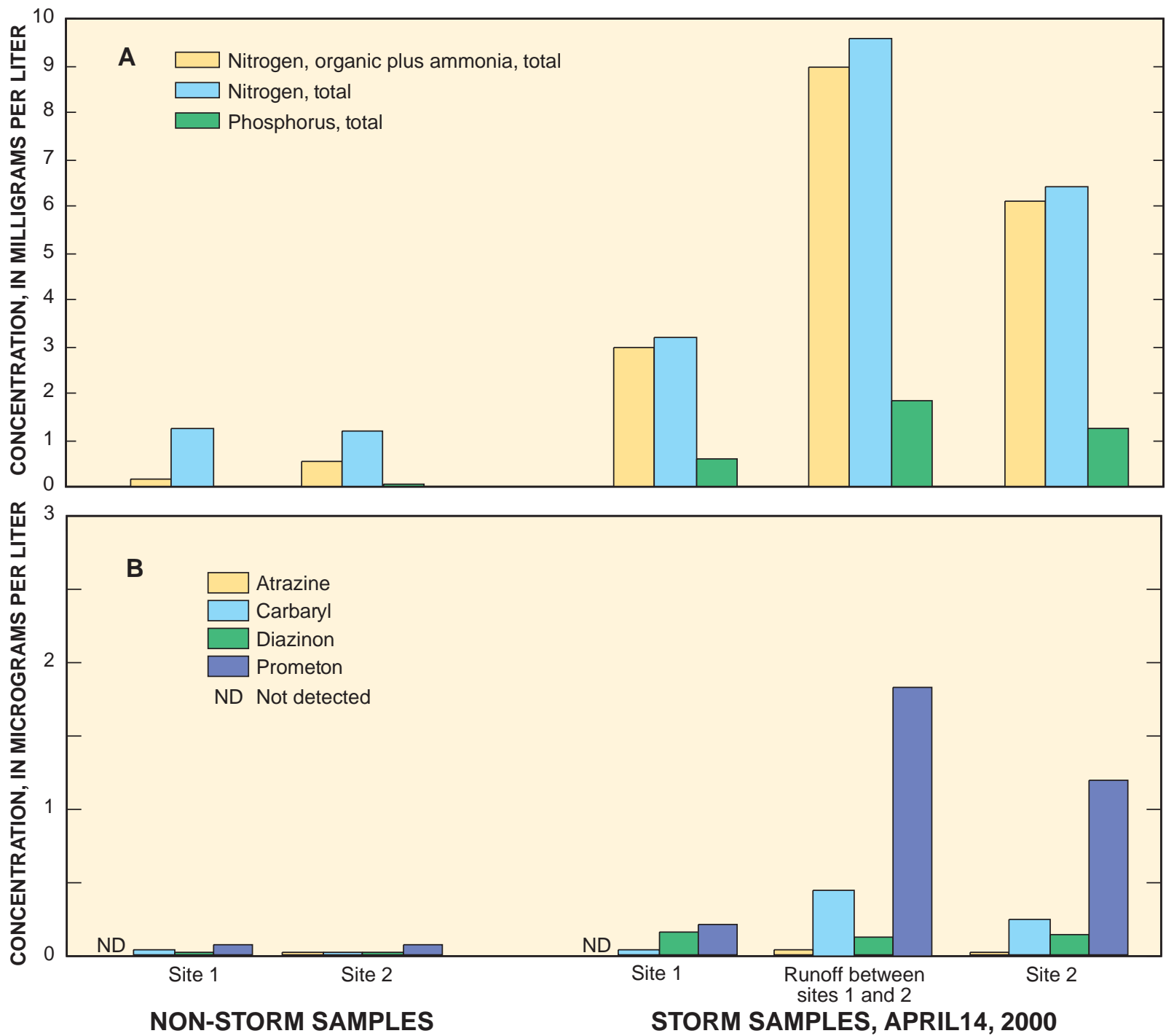

Figure 22. Relation of mean concentration of $(A)$ total ammonia plus organic nitrogen, total nitrogen, and total phosphorus, and (B) atrazine, carbaryl, diazinon, and prometon at sites 1 and 2, and in runoff between sites 1 and 2 in non-storm and storm samples, Little Cottonwood Creek, near Salt Lake City, Utah.

The hydrology of the urbanized reach of Little Cottonwood Creek is highly variable and complex because of the canals and diversion structures utilized by different water users. Source water for the urban reach of Little Cottonwood Creek varies spatially and seasonally. Sources include snowmelt, storm water, ground water, irrigation return, and water imported from the Jordan River. The effect that each of these sources has on stream quality varies seasonally and with streamflow. During this study, about 85 percent of the runoff at the mouth of Little Cottonwood Creek was from snowmelt. Ground-water inflow is a major source of water to the urbanized reach of Little Cottonwood Creek. A tracer injection and synoptic sampling during August 31 and September 2, 1999, showed that the ground-water component of streamflow was variable in the urbanized reach and accounted for 10 to 49 percent of total streamflow at the time of the synoptic study.

The Utah Division of Water Quality classifies water bodies in Utah according to type of water use to protect against controllable pollution. The urban reach of Little Cottonwood Creek, from the mouth of Little 
Cottonwood Canyon to the Jordan River, is designated for the beneficial uses of secondary contact recreation, cold water aquatic-life support, and agricultural uses.

Water temperature ranged from 0 to $29.6^{\circ} \mathrm{C}$ at site 1 and 0.1 to $26.2^{\circ} \mathrm{C}$ at site 2 . The maximum daily mean water temperature at both sites exceeded the Utah Class $3 \mathrm{~A}$ aquatic criterion for maximum temperature $\left(20^{\circ} \mathrm{C}\right)$ on many days. Daily mean specificconductance values at site 1 during water years 1999 and 2000 ranged from 99 to $5,290 \mu \mathrm{S} / \mathrm{cm}$. Daily mean specific-conductance values at site 2 during water years 1999 and 2000 ranged from 72 to $7,300 \mu \mathrm{S} / \mathrm{cm}$. The $\mathrm{pH}$ ranged from 7.5 to 8.6 at site 1 and 7.6 to 8.4 at site 2 and falls within National and Utah established criteria for aquatic organisms. Dissolved oxygen measurements were mostly near or above saturation at site 1 . Dissolved-oxygen measurements were mostly near or below saturation at site 2 .

Variations in the concentration of dissolved solids and major inorganic chemical composition of water at sites 1 and 2 generally are associated with seasonal snowmelt runoff, winter storm runoff, spring storms, and diversions and imports of irrigation water. The dissolved-solids concentration in samples collected at site 1 generally was lower than that in samples collected at site 2 . The exception was during winter low flow when higher concentrations of dissolved solids sometimes occurred at site 1 when storm runoff made up a higher percentage of total streamflow relative to site 2 . Calcium and bicarbonate were most often the dominant ions at site 1 . Sodium and chloride were most often the dominant ions at site 2 .

The median concentration of nitrite plus nitrate at sites 1 and 2 was near the estimated baseline concentration of $0.6 \mathrm{mg} / \mathrm{L}$ nitrate for undeveloped areas, which is an indication that nitrite plus nitrate concentrations in the urbanized reach of Little Cottonwood Creek are generally low. The USEPA recommends a limit of $0.10 \mathrm{mg} / \mathrm{L}$ total phosphorus to control excessive growth of algae and other nuisance plants in streams. At site 1 the total concentration of phosphorus ranged from 0.004 (estimated) $\mathrm{mg} / \mathrm{L}$ to $0.827 \mathrm{mg} / \mathrm{L}$ and exceeded $0.10 \mathrm{mg} / \mathrm{L}$ in 5 of 29 samples. At site 2, total phosphorus concentration ranged from 0.029 to $2.39 \mathrm{mg} / \mathrm{L}$ and exceeded 0.10 $\mathrm{mg} / \mathrm{L}$ in 15 of the 45 samples.

Past mining activities and ore smelting operations continue to influence the water chemistry of the stream. Arsenic was detected in all 49 samples collected at site 2 with concentrations ranging from 4.7 to $284 \mu \mathrm{g} / \mathrm{L}$. The concentration of arsenic in eight samples from site 2 exceeded the USEPA aquatic-life criterion of $150 \mu \mathrm{g} / \mathrm{L}$. Synoptic sampling during August 1999 in the urban reach between sites 1 and 2 on Little Cottonwood Creek indicated surface runoff and sub-surface drainage in the vicinity of site S20 near the Murray smelter tailings as likely sources of arsenic solutes.

Eighteen of the 107 pesticides analyzed for in this study were detected in at least 1 sample at site 1 , and 32 of the 107 pesticides sampled for in this study were detected in at least 1 sample at site 2 . The detected pesticides include 23 herbicides, 4 herbicide metabolites, 5 insecticides, and 1 fungicide. Prometon was the most frequently detected pesticide. Prometon concentration was the highest measured among all detected pesticides, as high as $0.978 \mu \mathrm{g} / \mathrm{L}$ at site 1 and $5.61 \mu \mathrm{g} / \mathrm{L}$ at site 2 . Diazinon was the second most frequently detected pesticide and exceeded the aquaticlife criterion of $0.08 \mu \mathrm{g} / \mathrm{L}$ in 12 of 51 samples. The highest concentration of diazinon was $0.343 \mu \mathrm{g} / \mathrm{L}$ at site 2. Concentrations of the insecticides malathion and carbaryl also exceeded the aquatic-life criteria.

Samples collected from sites 1 and 2 were analyzed for 86 volatile organic compounds. Three compounds were detected at site 1 and 28 compounds were detected at site 2 . Fuel-related BTEX compounds (benzene, toluene, ethyl benzene, and the xylenes) were the most frequently detected group of VOCs at site 2 , followed closely by solvents. Toluene was detected in 94 percent of the samples from site 2 and was the most frequently detected VOC. Acetone was the VOC detected in the highest concentration, at a maximum concentration of $20 \mu \mathrm{g} / \mathrm{L}$. Toluene was the only VOC that exceeded established aquatic-life criteria. It was detected at a maximum concentration of $3.15 \mu \mathrm{g} / \mathrm{L}$, exceeding the aquatic-life criterion of 2 $\mu \mathrm{g} / \mathrm{L}$.

Storm runoff from the urbanized area of the Little Cottonwood Creek drainage basin is a substantial source of nutrients and pesticides to Little Cottonwood Creek. Elevated concentrations of nutrients and pesticides in samples collected during spring and summer storms at sites 1 and 2 indicate that accumulations of these constituents in the urban area are being transported to the stream in storm runoff. Nutrients and pesticides can be present in a much higher concentration in samples with storm runoff than in non-storm samples. Mean concentration of total 
ammonia plus organic nitrogen, total nitrogen (total ammonia + organic nitrogen + nitrite + nitrate), and total phosphorus calculated for runoff between sites 1 and 2 for the April 14, 2000, storm were much higher than those measured in non-storm samples collected at the fixed sites. Similarly, mean concentrations of atrazine, carbaryl, diazinon, and prometon calculated in the runoff from the April 14, 2000, storm were much higher than those of non-storm samples.

Specific-conductance values and chloride concentration increased in the urbanized reach of Little Cottonwood Creek during and following most winter storms. These increases were likely the result of road salting. The USEPA has recommended that the concentration of chloride not exceed $860 \mathrm{mg} / \mathrm{L}$ for more than 1 hour every 3 years or a 4-day average concentration of $230 \mathrm{mg} / \mathrm{L}$ more than once every 3 years. Estimates of chloride concentration determined from specific-conductance values indicate that chloride concentrations at site 2 exceeded $860 \mathrm{mg} / \mathrm{L}$ about 9 percent of the time during December through March, and a 4-day average of $230 \mathrm{mg} / \mathrm{L}$ was exceeded more than 30 times during the study period. A higher percentage of algae were identified in taxa more tolerant of salinity in samples from site 2 than from site 1 , most likely because water with a higher salinity enters the stream between sites 1 and 2 .

\section{REFERENCES CITED}

Anderson, J.R., Hardy, E.E., Roach, J.T., and Witmer, R.E., 1976, A land use and land cover classification system for use with remote sensor data: U.S. Geological Survey Professional Paper 964, 28 p.

Baskin, R.L., Thiros, S.A., Giddings, E.M., Hadley, H.K., Gerner, S.J., Stephens, D.W., Waddell, K.M., 2002, Water-quality assessment of the Great Salt Lake Basins, Utah, Idaho, and Wyoming-Environmental setting and study design: U.S. Geological Survey Water-Resources Investigations Report 02-4115, 47 p.

Broshears, R.E., Bencala, K.E., Kimball, B.A., and McKnight, D.M., 1993, Tracer-dilution experiments and solute-transport simulations for a mountain stream, Saint Kevin Gulch, Colorado: U.S. Geological Survey Water-Resources Investigations Report 92-4081, 18 p.

Calkins, F.C., and Butler, B.S., 1943, Geology and ore deposits of the Cottonwood-American Fork area, Utah: U.S. Geological Survey Professional Paper 201, 152 p.
Canadian Council of Ministers of the Environment, 2001, Canadian water quality guidelines for the protection of aquatic life: Summary table, accessed June 27, 2001, at http://www.ec.gc.ca/ceqg-rcqe

Capel, P.D., Spexet, A.H., and Larson, S.J., 1999, Occurrence and behavior of the herbicide prometon in the hydrologic system: Environmental Science and Technology, v. 33, no. 5, p. 674-680.

Edwards, T.K., and Glysson, G.D., 1988, Field methods for measurement of fluvial sediment: U.S. Geological Survey Open-File Report 86-531, 118 p.

Environment Canada, 2001, Priority substances list assessment report - road salt, accessed February 1, 2002, at http://www.ec.gc.ca/substances/ese/eng/ psap/final/reports/Road_salt.pdf

Gerner, L.J., Rossi, F.J., and Kimball, B.A., 2001, Selected hydrologic data for Little Cottonwood Creek, Salt Lake County, Utah, September 1998: U.S. Geological Survey Open-File Report 01-38, 2 sheets.

Gilliom, R.J., Alley, W.M., and Gurtz, M.E., 1995, Design of the National Water-Quality Assessment Program: Occurrence and distribution of water-quality conditions: U.S. Geological Survey Circular 1112, 33 p.

Hem, J.D., 1992, Study and interpretation of chemical characteristics of natural water: U.S. Geological Survey Water-Supply Paper 2254, 263 p.

Herbert, L.R., Allen, D.V., Wilberg, D.E., and Tibbets, J.R., 2000, Water Resources Data, Utah, Water Year 1999: U.S. Geological Survey Water-Data Reports UT-99-1, $340 \mathrm{p}$.

Herbert, L.R., Wilberg, D.E., Tibbets, J.R., and Allen, D.V., 2001, Water Resources Data, Utah, Water Year 2000: U.S. Geological Survey Water-Data Reports UT-00-1, $380 \mathrm{p}$.

Herbert, L.R., Wilberg, D.E., and Tibbets, J.R., 2002, Water Resources Data, Utah, Water Year 2001: U.S. Geological Survey Water-Data Reports UT-01-1, 440 p.

International Joint Commission, United States and Canada, 1989, Revised Great Lakes water quality agreement of 1978, accessed on April 15, 2000, at http://www.ijc.org/ agree/quality.html\#art5

Larson, S.J., Capel, P.D., and Majewski, M.S., 1997, Pesticides in surface waters - distribution, trends, and governing factors: Chelsea, Mich., Ann Arbor Press, $373 \mathrm{p}$.

Mueller, D.K., Hamilton, P.A., Helsel, D.R., 1995, Nutrients in ground water and surface water of the United States An analysis of data through 1992: U.S. Geological Survey Water-Resources Investigations Report 954031, 74 p.

Mueller, D.K., Martin, J.D., and Lopes, T.J., 1997, Qualitycontrol design for surface-water sampling in the National Water-Quality Assessment Program: U.S. Geological Survey Open-File Report 97-223, 17 p. 
Munn, M.D., and Gilliom, R.J., 2001, Pesticide toxicity index for freshwater aquatic organisms: U.S. Geological Survey Water-Resources Investigations Report 01-4077, 55 p.

Porterfield, G., 1972, Computation of fluvial-sediment discharge, U.S. Geological Survey Techniques of Water-Resources Investigations, book 3, chap. C3, 66 p.

Rowe, B.L., Landrigan, S.J., Lopes, T.J., 1997, Summary of published aquatic toxicity information and waterquality criteria for selected volatile organic compounds: U.S. Geological Survey Open-File Report 97-563, 60 p.

Shelton, L.R., 1994, Field guide for collecting and processing stream-water samples for the National Water-Quality Assessment Program: U.S. Geological Survey Open-File Report 94-455, 42 p.

1997, Field guide for collecting samples for analysis of volatile organic compounds in stream water for the National Water-Quality Assessment Program: U.S. Geological Survey Open-File Report 97-401, 14 p.

Stephens, D.W., 1984, Dissolved-oxygen regime of the Jordan River, Salt Lake County, Utah: U.S. Geological Survey Water-Resources Investigations Report 844056, $56 \mathrm{p}$.

Stumm, Werner, and Morgan, J.J., 1996, Aquatic chemistry: Chemical equilibria and rates in natural waters: New York, Wiley Interscience, 1022 p.

U.S. Environmental Protection Agency, 1986, Quality criteria for water-1986: U.S. Environmental Protection Agency Report EPA 440/5-86-001. 1988, Ambient Water Quality Criteria for Chloride: U.S. Environmental Protection Agency Report EPA 440/5-88-001, 39 p. 1998a, Record of Decision Abstract - Murray Smelter, accessed April 8, 2001, at http://www.epa.gov/ superfund/sites/rodsites/0800697

1998b, National strategy for the development of regional nutrient criteria: U.S. Environmental Protection Agency Report EPA 822-R-98-002, 52 p. 1999, National recommended water quality criteria correction: U.S. Environmental Protection Agency Report EPA 822-Z-99-001, accessed May 21, 2001, at http://www.epa.gov/OST/standards/wqcriteria.html

2002, 2002 edition of the drinking water standards and health advisories: U.S. Environmental Protection Agency Report EPA 822-R-02-038, accessed October 21, 2002, at http://www.epa.gov/OST/drinking/ standards

Utah Department of Environmental Quality, 1997, Standards of quality for waters of the State, R317-2, Utah Administrative Code, accessed April 13, 2001, at http://www.rules.utah.gov/publicat/code/r317/r317002.htm
Wood, A.J., Lammers, D.A., Bryce, S.A., Omernik, J.M., Denton, R.L., Domeier, M., and Comstock, J.A., 2001, Ecoregions of Utah (color poster with map, descriptive text, summary tables, and photographs): Reston, Virginia, U.S. Geological Survey (map scale $1: 1,175,000)$. 


\section{APPENDIX}

\section{QUALITY-CONTROL PROCEDURES AND RESULTS}

Quality-control (QC) samples were collected during the study following NAWQA protocols (Shelton, 1994; Mueller and others, 1997). Samples consisted of field-blanks, equipment blanks, replicates, and field matrix spikes. QC samples collected at the Little Cottonwood Creek fixed sites are part of a larger group of samples collected at 10 Great Salt Lake Basins study unit fixed sites. Analysis of QC samples collected only from sites on Little Cottonwood Creek would not be statistically significant and, therefore, these samples have been combined with those collected at eight additional Great Salt Lake Basins study unit surface-water fixed sites from October 1998 to September 2000.

Field blanks are collected and analyzed to estimate bias in environmental samples. They demonstrate whether or not equipment has been adequately cleaned and whether sample collection, processing, and handling have introduced contaminants into the sample. Low concentrations of contaminants in field blanks could cause a positive bias in environmental samples with low concentrations of those contaminants. Contamination is considered significant if it exceeds 10 percent of the concentration measured in environmental samples. Some major ions, pesticides, dissolved organic carbon, and VOCs were detected in field blanks, but not at a concentration and frequency high enough to indicate a positive bias in environmental samples (table 9). Several nutrient constituents were detected in blank samples. Total ammonia plus organic nitrogen was the most frequently detected nutrient with a maximum concentration of $0.386 \mathrm{mg} / \mathrm{L}$ and a median concentration of $0.053 \mathrm{mg} / \mathrm{L}$. The range for concentration of total ammonia plus organic nitrogen for all samples at Little Cottonwood Creek fixed sites ranged from 0.10 to $11.0 \mathrm{mg} / \mathrm{L}$ and the median concentration was $0.35 \mathrm{mg} / \mathrm{L}$. Zinc and aluminum were detected in field blanks at concentrations and frequencies high enough that most sample results have been prefaced with a 'v' remark code, indicating that the environmental-sample values have been affected by contamination. The range of zinc contamination in blank samples was 2.7 to $15.1 \mu \mathrm{g} / \mathrm{L}$.
The concentration of zinc in all samples at Little Cottonwood Creek fixed sites ranged from less than 1.0 to $58 \mu \mathrm{g} / \mathrm{L}$ and the median concentration was $16 \mu \mathrm{g} / \mathrm{L}$.

On the basis of QC results, it was concluded that measurements of concentrations in the environmental samples were of sufficiently high quality that the presence or absence of most constituents, concentration distributions, and comparisons to water-quality criteria could be determined. Sample concentrations of total and dissolved organic ammonia plus nitrogen and orthophosphate may be biased high as a result of contamination. Sample concentrations of aluminum and zinc, near the MRL, are probably biased high as a result of contamination.

A surrogate solution, containing a series of organic compounds of known concentration, was added to every environmental pesticide and VOC sample. The surrogate compounds were expected to behave in a manner similar to target analytes, yet not be present in the environment. Recovery of surrogate analytes for pesticide samples analyzed by using GC/MS ranged from 53 percent to 146 percent (table 10). Recovery of surrogate analytes from VOC samples ranged from 70 percent to 118 percent.

Field matrix spike samples consisted of an environmental sample split into subsamples with a series of organic compounds that were contained in the analytical schedule added to one subsample. Matrix spike samples were used to assess extraction and elution recoveries from field matrices and to evaluate the precision of results for the target analytes in different environmental matrices (Shelton, 1994). Recovery of field spike solution analytes for pesticides analyzed with the GC/MS method ranged from 24 percent to 221 percent (table 10).

Recoveries of the surrogate and most analytes in field matrix spike samples analyzed for pesticides with the HPLC/MS method were less than 100 percent in more than half the samples. A laboratory detection with this method meant it was likely that the analyte was present; however, non-detections of other target analytes did not necessarily mean that they were not present.

Sample replicates were collected to provide an estimate of the variability of sample results. All replicates were split samples, in which one water sample was split into subsamples. These provide an estimate of variability associated with sample processing, handling, and analysis. Split samples will not provide an estimate of variability associated with 
sample collection. Relative differences for pesticides ranged from 0 to 80.7 percent (table 11). The median relative difference was 10.5 percent. The relative difference for nutrients ranged from 0 to 41.6 percent, with a median relative difference of 3.6 percent. Majorion samples had the smallest relative difference among split samples, ranging from 0 to 30 percent, with a median of 0.3 percent. 
Table 9. Summary of constituents detected in field blanks collected from basic fixed sites in the Great Salt Lake Basins study unit [e, estimated; mg/L, milligrams per liter; $\mu \mathrm{g} / \mathrm{L}$, micrograms per liter; GC/MS, gas chromatography/mass spectrometry]

\begin{tabular}{|c|c|c|c|c|c|}
\hline \multirow{2}{*}{ Constituent group } & \multirow{2}{*}{ Constituent } & \multirow{2}{*}{$\begin{array}{c}\text { Number of } \\
\text { samples }\end{array}$} & \multirow{2}{*}{ Detections } & \multicolumn{2}{|c|}{ Concentration } \\
\hline & & & & Maximum & Minimum \\
\hline \multirow[t]{4}{*}{ Major ions } & Magnesium & 9 & 1 & 0.002 e $\mathrm{mg} / \mathrm{L}$ & 0.002 e $\mathrm{mg} / \mathrm{L}$ \\
\hline & Sodium & 9 & 2 & $.06 \mathrm{e} \mathrm{mg/L}$ & $.058 \mathrm{mg} / \mathrm{L}$ \\
\hline & Chloride & 9 & 1 & $.62 \mathrm{mg} / \mathrm{L}$ & $.62 \mathrm{mg} / \mathrm{L}$ \\
\hline & Silica & 9 & 1 & $.113 \mathrm{mg} / \mathrm{L}$ & $.113 \mathrm{mg} / \mathrm{L}$ \\
\hline \multirow[t]{4}{*}{ Nutrients } & Nitrogen, organic plus ammonia, dissolved & 10 & 2 & $.06 \mathrm{mg} / \mathrm{L}$ & $.052 \mathrm{mg} / \mathrm{L}$ \\
\hline & Nitrogen, organic plus ammonia, total & 10 & 3 & $.386 \mathrm{mg} / \mathrm{L}$ & $.051 \mathrm{mg} / \mathrm{L}$ \\
\hline & Dissolved phosphorus & 10 & 2 & $.005 \mathrm{mg} / \mathrm{L}$ & .004 mg/L \\
\hline & Orthophosphate & 10 & 2 & $.021 \mathrm{mg} / \mathrm{L}$ & $.014 \mathrm{mg} / \mathrm{L}$ \\
\hline \multirow[t]{2}{*}{ Trace elements } & Zinc & 3 & 2 & $15.1 \mu \mathrm{g} / \mathrm{L}$ & $2.65 \mu \mathrm{g} / \mathrm{L}$ \\
\hline & Aluminum & 3 & 2 & $9.85 \mu \mathrm{g} / \mathrm{L}$ & $2.89 \mu \mathrm{g} / \mathrm{L}$ \\
\hline Pesticides (GC/MS) & Tebuthiuron & 11 & 1 & .007 e $\mu \mathrm{g} / \mathrm{L}$ & .007 e $\mu \mathrm{g} / \mathrm{L}$ \\
\hline Volatile organic compounds & Toluene & 4 & 1 & $.015 \mathrm{e} \mu \mathrm{g} / \mathrm{L}$ & .015 e $\mu \mathrm{g} / \mathrm{L}$ \\
\hline
\end{tabular}

Table 10. Summary of surrogate and field matrix spike recovery in water samples collected from basic fixed sites in the Great Salt Lake Basins study unit [GC/MS, gas chromatography/mass spectrometry]

\begin{tabular}{|c|c|c|c|c|c|c|c|}
\hline \multirow{2}{*}{ Type of spike } & \multirow{2}{*}{$\begin{array}{l}\text { Number of } \\
\text { Samples }\end{array}$} & \multicolumn{6}{|c|}{$\begin{array}{c}\text { Spike recovery } \\
\text { (percent) }\end{array}$} \\
\hline & & Minimum & 25th percentile & Mean & 75th percentile & Maximum & $\begin{array}{l}\text { Standard } \\
\text { deviation }\end{array}$ \\
\hline \multicolumn{8}{|c|}{ Pesticide surrogate } \\
\hline Diazinon D10 & ${ }^{1} 224$ & 69 & 98 & 106 & 114 & 146 & 12 \\
\hline HCH, ALPHA D6 & $1_{224}$ & 53 & 90 & 96 & 102 & 135 & 11 \\
\hline \multicolumn{8}{|c|}{ Volatile organic compound surrogate } \\
\hline Benzene, 1,4-Bromo Fluoro- & 76 & 70 & 89 & 95 & 103 & 118 & 12 \\
\hline Ethane, 1,2-Dichloro, D4- & 76 & 89 & 101 & 104 & 107 & 117 & 5 \\
\hline Toluene, D8 & 76 & 87 & 98 & 100 & 103 & 111 & 4 \\
\hline \multicolumn{8}{|c|}{ Pesticide, field matrix spike - all analytes } \\
\hline Sample 1 (GC/MS) & 1 & 36 & 107 & 113 & 122 & 221 & 28 \\
\hline Sample 2 (GC/MS) & 1 & 61 & 93 & 106 & 115 & 176 & 25 \\
\hline Sample 3 (GC/MS) & 1 & 58 & 93 & 107 & 117 & 197 & 27 \\
\hline Sample 4 (GC/MS) & 1 & 45 & 87 & 102 & 113 & 178 & 28 \\
\hline Sample 5 (GC/MS) & 1 & 42 & 92 & 105 & 120 & 178 & 28 \\
\hline Sample 6 (GC/MS) & 1 & 24 & 91 & 100 & 110 & 134 & 20 \\
\hline Sample 7 (GC/MS) & 1 & 59 & 98 & 106 & 115 & 150 & 19 \\
\hline Sample 8 (GC/MS) & 1 & 52 & 92 & 105 & 109 & 179 & 24 \\
\hline Sample 9 (GC/MS) & 1 & 50 & 95 & 104 & 111 & 176 & 22 \\
\hline Sample 10 (GC/MS) & 1 & 31 & 79 & 89 & 99 & 124 & 18 \\
\hline Sample 11 (GC/MS) & 1 & 47 & 89 & 100 & 113 & 161 & 21 \\
\hline Sample 12 (GC/MS) & 1 & 46 & 81 & 97 & 110 & 192 & 25 \\
\hline Sample 13 (GC/MS) & 1 & 39 & 94 & 101 & 115 & 155 & 21 \\
\hline \multicolumn{8}{|c|}{ Volatile organic compounds, field matrix spike - all analytes } \\
\hline Sample 1 & 1 & 28 & 75 & 81 & 88 & 146 & 16 \\
\hline
\end{tabular}


Table 11. Summary of relative percent difference between constituents detected in split replicate sample pairs collected from fixed sites in the Great Salt Lake Basins study unit

[nd, not detected; - , not sampled]

\begin{tabular}{|c|c|c|c|c|c|c|c|}
\hline \multirow{2}{*}{ Constituent } & \multicolumn{7}{|c|}{$\begin{array}{l}\text { Relative difference } \\
\text { (percent) }\end{array}$} \\
\hline & Pair 1 & Pair 2 & Pair 3 & Pair 4 & Pair 5 & Pair 6 & Pair 7 \\
\hline Atrazine & 9.7 & 0.4 & 12.7 & 61.3 & 2.3 & 12.1 & 27.2 \\
\hline Carbaryl & nd & nd & nd & 13.0 & nd & 80.7 & nd \\
\hline Chloropyrifos & nd & 41.6 & nd & nd & nd & nd & nd \\
\hline Dacthal & nd & 5.4 & nd & nd & nd & nd & nd \\
\hline Deethylatrazine & nd & 6.5 & 4.2 & 4.8 & 1.7 & 3.0 & 32.1 \\
\hline Diazinon & nd & 40.0 & nd & 2.2 & nd & 14.8 & 22.2 \\
\hline Malathion & nd & nd & nd & nd & nd & 10.5 & 9.5 \\
\hline Prometon & nd & 3.8 & 3.0 & nd & 13.0 & 18.0 & 22.2 \\
\hline Simazine & nd & 8.4 & nd & nd & 10.0 & 45.5 & nd \\
\hline Nitrogen, ammonia, dissolved & 20.4 & nd & 2.1 & nd & nd & nd & nd \\
\hline $\begin{array}{l}\text { Nitrogen, organic plus ammonia, } \\
\text { dissolved }\end{array}$ & 4.2 & 4.0 & 3.0 & 10.9 & 8.6 & 2.4 & 1.7 \\
\hline Nitrogen, organic plus ammonia, total & 1.7 & 41.6 & 8.5 & 18.3 & 38.2 & .9 & 3.1 \\
\hline Nitrogen, nitrite plus nitrate, dissolved & .5 & .0 & 2.9 & 1.0 & 1.3 & 3.6 & 4.9 \\
\hline Nitrogen, nitrite, dissolved & 6.9 & nd & 5.4 & nd & nd & 4.0 & .0 \\
\hline Phosphorus, dissolved & 1.0 & .0 & 18.9 & nd & 6.5 & 7.1 & 7.4 \\
\hline Orthophosphorus & 1.6 & nd & 5.0 & nd & nd & nd & nd \\
\hline Phosphorus, total & .6 & 2.5 & 6.5 & nd & 5.4 & 1.7 & 3.6 \\
\hline Calcium & .3 & .0 & .6 & .0 & .5 & .7 & - \\
\hline Chloride & .2 & .4 & .5 & .5 & .9 & .7 & - \\
\hline Fluoride & 10.9 & .8 & .3 & .4 & 2.5 & nd & - \\
\hline Iron & nd & nd & 5.9 & 12.9 & 4.1 & nd & - \\
\hline Magnesium & .3 & .0 & .6 & .5 & .5 & .9 & - \\
\hline Potassium & .1 & .5 & .5 & .2 & .3 & 4.7 & - \\
\hline Silica & .6 & .1 & .4 & .2 & .0 & .8 & - \\
\hline Sodium & 1.0 & .2 & .4 & .8 & .7 & 1.1 & - \\
\hline Sulfate & .0 & 30.0 & .1 & .0 & .1 & .1 & - \\
\hline Dissolved solids, residue on evaporation & .1 & .1 & .0 & .2 & .5 & .4 & - \\
\hline $\mathrm{pH}$ & .1 & .1 & .0 & .0 & .2 & .3 & - \\
\hline Specific conductance & .1 & .1 & .0 & .2 & .0 & .1 & - \\
\hline Suspended organic carbon & 13.0 & .0 & 4.0 & - & - & - & - \\
\hline Dissolved organic carbon & 0 & .0 & 12.2 & .6 & 3.3 & 11.8 & - \\
\hline Aluminum & 81.9 & 14.0 & nd & - & - & - & - \\
\hline Antimony & 2.2 & 2.8 & .3 & - & - & - & - \\
\hline Arsenic & nd & .9 & 1.4 & - & - & - & - \\
\hline Barium & 4.1 & .5 & 1.0 & - & - & - & - \\
\hline Copper & 5.3 & 5.6 & .8 & - & - & - & - \\
\hline Lead & nd & nd & 1.3 & - & - & - & - \\
\hline Molybdenum & 1.9 & .7 & .7 & - & - & - & - \\
\hline Selenium & 31.0 & 2.4 & 22.1 & - & - & - & - \\
\hline Uranium, natural & 6.0 & 1.2 & .8 & - & - & - & - \\
\hline Zinc & 4.3 & 3.7 & 1.9 & - & - & - & - \\
\hline
\end{tabular}




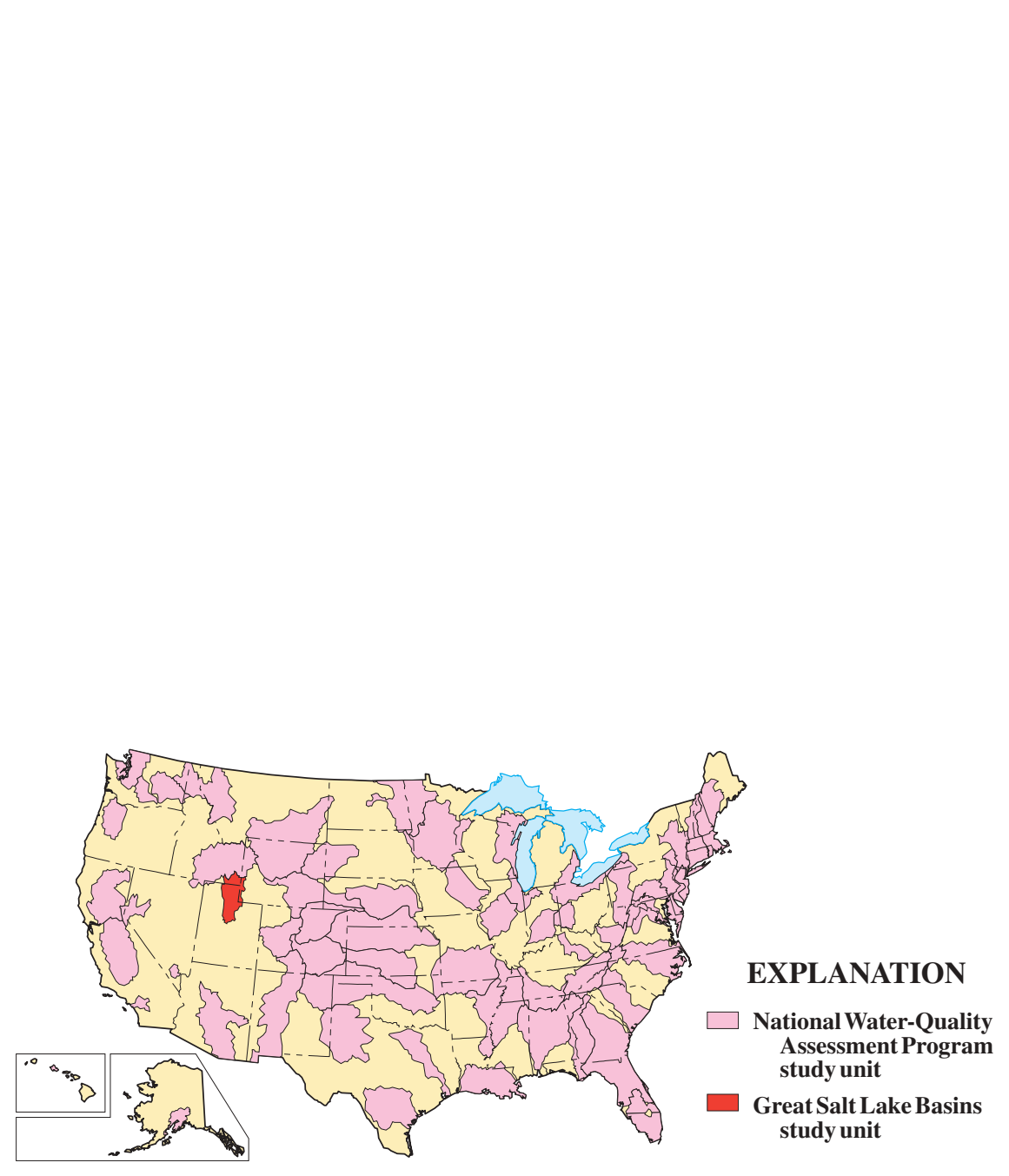

